\title{
War Everywhere: Rights, National Security Law, and the Law of Armed Conflict in the Age of Terror
}

Rosa Ehrenreich Brooks

Georgetown University Law Center, rosa.brooks@law.georgetown.edu

Georgetown Public Law and Legal Theory Research Paper No. 12-175

This paper can be downloaded free of charge from:

https://scholarship.law.georgetown.edu/facpub/1125

http://ssrn.com/abstract=573321

153 U. Pa. L. Rev. 675-761 (2004)

This open-access article is brought to you by the Georgetown Law Library. Posted with permission of the author. Follow this and additional works at: https://scholarship.law.georgetown.edu/facpub

Part of the Constitutional Law Commons, Human Rights Law Commons, International Law Commons, Military, War, and Peace Commons, and the National Security Law Commons 


\title{
WAR EVERYWHERE: RIGHTS, NATIONAL SECURITY LAW, AND THE LAW OF ARMED CONFLICT IN THE AGE OF TERROR
}

\author{
ROSA EHRENREICH BROOKS ${ }^{\dagger}$
}

INTRODUCTION: AN OUTMODED LEGAL PARADIGM …………..............676

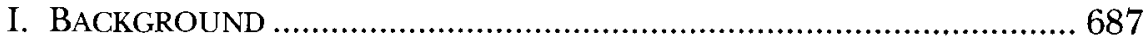

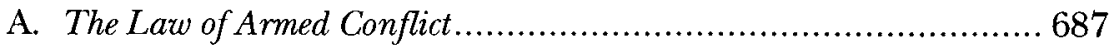

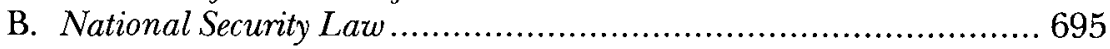

C. The Assumption of Clear Boundaries ....................................... 702

II. Changes: Globalization and Asymmetrical Threat ............... 705

III. THE BREAKDOWN OF BOUNDARIES ………………..................... 711

A. "International" Versus "Internal" Armed Conflicts ........................ 711

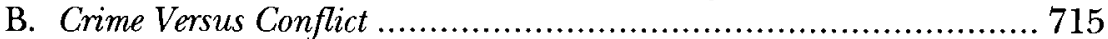

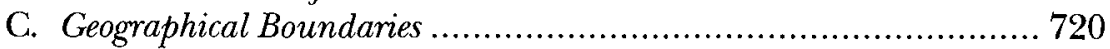

D. War Without End: Temporal Boundaries.................................. 725

E. We Are All at War: Distinctions Between Persons ........................ 729

F. The Boundaries Between National Security and Domestic Affairs...... 736

IV. IMPLICATIONS: WAR EVERYWHERE; RIGHTS NOWHERE .................. 744

V. WHAT CAN BE DONE? HUMAN RightS LAW AS A BaSis FOR

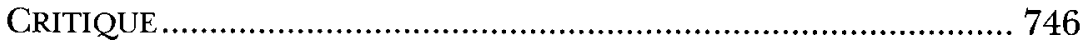

VI. REINVENTING THE LAW OF ARMED CONFLICT ............................. 755

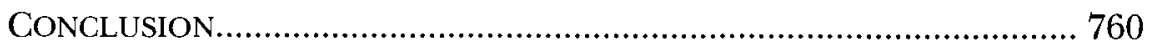

${ }^{\dagger}$ Associate Professor of Law, University of Virginia School of Law. I am grateful to Lt. Col. Kevin S. Donohue, U.S. Army (ret.), Virginia Law '05, for providing exceptionally high caliber research assistance for this article. I am also grateful to participants in a University of Virginia faculty workshop for extremely helpful comments. I owe particular thanks to Peter Brooks, Dave Martin, and Paul Stephan. Thanks are also due to Jane Stromseth and David Wippman, and to the participants in a May 2004 roundtable on International Humanitarian Law and the Challenge of Terrorism, sponsored jointly by the Open Society Institute and the Notre Dame Center for Civil and Human Rights. 


\section{INTRODUGTION: AN OUTMODED LEGAL PARADIGM}

Others say, Law is our Fate;

Others say, Law is our State;

Others say, others say

Law is no more,

Law has gone away. ${ }^{1}$

Both international and domestic law take as a basic premise the notion that it is possible, important, and usually fairly straightforward to distinguish between war and peace, emergencies and normality, the foreign and the domestic, the external and the internal. From an international law perspective, the law of armed conflict ${ }^{2}$ is triggered only when an armed conflict actually exists; ${ }^{3}$ the rest of the time, other bodies of law are applicable. ${ }^{4}$ Domestically, U.S. courts have developed a constitutional and statutory jurisprudence that attempts to distinguish between "national security" issues and "domestic" questions, with the courts subjecting government actions to far less scrutiny when those actions are taken in the name of national security. ${ }^{5}$

${ }^{1}$ W.H. Auden, Law like Love, in Collected POEMS 262, 263 (Edward Mendelson ed., 1991).

${ }^{2}$ There is some debate about the most appropriate term for the body of customary and treaty-based law that deals with armed conflict, but throughout this Article I use the phrase the "law of armed conflict" as the most inclusive and widely accepted term. The "law of war" and "international humanitarian law" are both often used interchangeably with the "law of armed conflict," but at times I use each of these terms in a narrower sense.

"The law of armed conflict is "lex specialis," applying only to situations of armed conflict, but trumping other legal regimes during periods of armed conflict.

${ }^{4}$ See, e.g., Ruti G. Teitel, Humanity's Law: Rule of Law for the New Global Politics, 35 CORNELL INT'L L.J. 355, 375 (2002) (asserting that "the law of war limits state action in periods of conflict and human rights law limits state behavior in periods of peace" (footnote omitted)).

${ }^{5}$ See, e.g., Johnson v. Eisentrager, 339 U.S. 763, 786-87 (1950) (holding that the courts have no power of judicial review over decisions of military tribunals adjudicating the offenses of enemy aliens during wartime); United States v. Curtiss-Wright Exp. Corp., 299 U.S. 304, 318 (1936) (vesting the federal government with the power necessary "to maintain an effective control of international relations"); see also WILLIAM H. REHNQUIST, ALI. THE LAWS BUT ONE: CIVIL IJIBERTIES IN WARTIME 222 (1998) ("In any civilized society the most important task is achieving a proper balance between freedom and order. In wartime, reason and history both suggest that this balance shifts to some degree in favor of order-... the government's ability to deal with conditions that threaten the national well-being."). 
This Article asserts that these binary distinctions are no longer tenable. In almost every sphere, globalization has complicated oncestraightforward legal categories, but this is nowhere more apparent and more troubling than in the realms of armed conflict and national security law. Although the boundaries between "war" and "nonwar," and between "national security" and "domestic issues," have been eroding for some time, September 11 and its aftermath have highlighted the increasing incoherence and irrelevance of these traditional legal categories. Shifts in the nature of security threats have broken down once clear distinctions between armed conflict and "internal disturbances" that do not rise to the level of armed conflict; between states and nonstate actors; between combatants and noncombatants; between spatial zones in which conflict is occurring and zones in which conflict is not occurring; between temporal moments in which there is no conflict and temporal moments in which there is conflict; and between matters that clearly affect the security of the nation and matters that clearly do not.

The breakdown of these once reasonably straightforward distinctions gave the U.S. government an opening to argue, among other things, that noncitizen detainees held at Guantanamo Bay, Cuba may be detained indefinitely without charge, ${ }^{6}$ that U.S. citizens (including those detained inside the U.S.) may be designated "unlawful combatants" by executive fiat and held indefinitely without charge or access to attorneys; ${ }^{7}$ and that the U.S. may kill any suspected terrorist in any

${ }^{6}$ See, e.g., News Release, U.S. Department of Defense, DOD Announces Draft Detainee Review Policy (Mar. 3, 2004) (" $[\mathrm{T}]$ he law of war permits the detention of enemy combatants for the duration of the conflict. It permits this detention without the use of a review process."), available at http://www.dod.gov/releases/2004/nr200403030403.html; see also Richard J. Wilson, United States Detainees at Guantánamo Bay: The Inter-American Commission on Human Rights Responds to a "Legal Black Hole", 10 HUM. RTS. BRIEF 2, 2 (2003) (noting that "the U.S. government continues to argue that the nearly 650 detainees from an estimated 40 nations are not entitled to any of the legal protections of U.S. domestic law or international human rights law").

See, e.g., Hamdi v. Rumsfeld, 124 S. Ct. 2633, 2636 (2004) ("The Government contends that Hamdi is an 'enemy combatant,' and that this status justifies holding him in the United States indefinitely-without formal charges or proceedings-unless and until it makes the determination that access to counsel or further process is warranted."). See generally Manooher Mofidi \& Amy E. Eckert, "Unlawful Combatants" or "Prisoners Of War": The Law and Politics of Labels, 36 CORNELL INT'L L.J. 59 (2003); Christopher M. Evans, Note, Terrorism on Trial: The President's Constitutional Authority to Order the Prosecution of Suspected Terrorists by Military Commission, 51 DUKE L.J. 1831 (2002); Anne English French, Note, Trials in Times of War: Do the Bush Military Commissions Sacrifice Our Freedoms?, 63 OHIO ST. L.J. 1225 (2002); Thomas J. Lepri, Note, Safeguarding the Enemy Within: The Need for Procedural Protections for U.S. Citizens Detained as Enemy Combatants Under Ex Parte Quirin, 71 FORDHAM L. REV. 2565 (2003); Robert K. 
state in the world at any time. ${ }^{8}$ U.S. courts are currently struggling to determine how to assess many of these claims, ${ }^{9}$ all of which are based on loose, but not implausible, readings of the law of armed conflict. ${ }^{10}$

Goldman \& Brian D. Tittemore, Unprivileged Combatants and the Hostilities in Afghanistan: Their Status and Rights Under International Humanitarian and Human Rights Law (Dec. 2002) (unpublished manuscript), available at http://www.asil.org/ taskforce/goldman.pdf.

${ }^{8}$ See, e.g., Goldman \& Tittemore, supra note 7, at 24 (citing President Bush's statement that while the United States has an "enduring commitment to the important principles of the [Third] Geneva Convention,... the war on terrorism is a war not envisioned when the Geneva Convention was signed in 1949" and that the Geneva Conventions "simply [do] not cover every situation in which people may be captured or detained, as we see in Afghanistan today" (alterations in original, omission added)); see also Fact Sheet: Status of Detainees at Guantanamo, White House Office of the Press Sec'y (Feb. 7,2002 ) (stating the government's position that the Geneva Conventions apply only to Taliban detainees, not al Qaida detainees, but that " $t]$ he United States is treating and will continue to treat all of the individuals detained at Guantanamo humanely and, to the extent, appropriate and consistent with military necessity, in a manner consistent with the principles of the Third Geneva Convention of 1949"), available at http://www.whitehouse.gov/news/releases/2002/02/20020207-13.html. Consider also the U.S. government's defense of the 2002 missile attack on suspected al Qaeda members in Yemen. National Security Advisor Condoleezza Rice later defended the attack, saying, "[t]he president has given broad authority to U.S. officials in a variety of circumstances to do what they need to do to protect the country." Interview with Condoleezza Rice, National Security Advisor, by Tony Snow, Fox News Sunday (Fox News television broadcast, Nov. 10, 2002) (transcript available at http:// www.foxnews.com/story/0,2933,69783,00.html). Rice has also asserted that "[w]e're in a new kind of war, and we've made very clear that it is important that this new kind of war be fought on different battlefields" and that "no constitutional questions are raised here.... [The killing was] well within the bounds of accepted practice . . .." Howard Witt, U.S.: Killing of al Qaeda Suspects Was Lawful, CHI. TRIB., Nov. 24, 2002, at 1.

${ }^{9}$ See e.g., Rumsfeld v. Padilla, 124 S. Ct. 2711, 2721-22 (2004) (holding that the commander of the naval brig where an alleged "enemy combatant" was held is a proper respondent to the habeas petition); Rasul v. Bush, 124 S. Ct. 2686, 2698 (2004) (stating that the district court had jurisdiction to hear the habeas challenges of "enemy combatants" held at Guantanamo Bay, Cuba); Hamdi, 124 S. Ct. at 2635 (holding that due process requires that a U.S. citizen detained in the United States as an "enemy combatant" must "be given a meaningful opportunity to contest the factual basis for that detention").

${ }^{10}$ Arguments for preemptive self-defense, which were also invoked in the context of the 2002 U.S. attack in Yemen, also rely on Article 2(4) of the United Nations Charter. U.N. CHARTER, art. 2, para. 4 ("Members shall refrain ... from the threat or use of force against the territorial integrity or political independence of any state.").

Bush administration lawyers also sought to use the increasing blurriness of law of armed conflict legal categories to assert that detainees in the war on terror could be subjected to harsh interrogation techniques, some of which constitute torture in the opinion of many outside legal experts. Unlike the various other administration arguments discussed above, which rest on loose but plausible readings of the law of armed conflict, the argument that harsh interrogation techniques are permissible for suspected terrorists is disingenuous. Regardless of which legal paradigm one chooses to invoke (criminal law, the law of armed conflict, human rights law, etc.), and regardless 
In response to these arguments, many in the human rights, civil rights, and international law communities have struggled to insist on the continuing viability of the law of armed conflict's traditional boundaries, "since the erosion of these boundaries has had (and will

of how one categorizes detainees (as POWs, unlawful comabatants, criminals, civilians, etc.), the minimum standards concerning humane treatment are essentially the same. Common Article 3 of the four Geneva Conventions of 1949 prohibits "cruel treatment and torture," as well as "outrages upon personal dignity, in particular, humiliating and degrading treatment." Geneva Convention for the Amelioration of the Condidition of the Wounded and Sick in Armed Forces in the Field, Aug. 12, 1949, art. 3, 6 U.S.T. 3114, 3116-18, 75 U.N.T.S. 31, 32-34 [hereinafter First Geneva Convention]; Geneva Convention for the Amelioration of the Condition of the Wounded, Sick and Shipwrecked Members of the Armed Forces at Sea, Aug. 12, 1949, art. 3, 6 U.S.T. 3217, 3220-22, 75 U.N.T.S. 85, 86-88 [hereinafter Second Geneva Convention]; Geneva Convention Relative to the Treatment of Prisoners of War, Aug. 12, 1949, art. 3, 6 U.S.T. 3316, 3318-20, 75 U.N.T.S. 135, 136-38 [hereinafter Third Geneva Convention]; Geneva Convention Relative to the Protection of Civilian Persons in Time of War, Aug. 12, 1949, art. 3, 6 U.S.T. 3516, 3518-20, 75 U.N.T.S. 287, 288-90 [hereinafter Fourth Geneva Convention] (I will refer to these conventions collectively as the 1949 Geneva Conventions). The Third Geneva Convention (on POWs) contains even stronger prohibitions, as does the Fourth Geneva Convention (on civilians). See Third Geneva Convention, supra, art. 4, 6 U.S.T. at 3320-22, 75 U.N.T.S. at 138-40; Fourth Geneva Convention, supra, art. 4, 6 U.S.T. at 3520, 75 U.N.T.S. at 290. The United States has also ratified the Convention Against Torture and Other Cruel, Inhuman, or Degrading Punishment, opened for signature Dec. 10, 1984, S. TREATY DoC. No. 100-20, at 19 (1988), 1465 U.N.T.S. 85 (entered into force June 26, 1987) [hereinafter Convention Against Torture], and Congress has passed implementing legislation making torture a federal crime, 18 U.S.C. $\$ \S 2340-2340$ A (2000).

Around the world, numerous courts (including the European Court of Human Rights) have fleshed out the meaning of terms such as torture and cruel or inhumane treatment, and there can be no serious disagreement that many of the Pentagon's approved interrogation techniques run afoul of international standards. See, e.g., Ilascu v. Moldova, App. No. 48787/99 (Eur. Ct. H.R. July 8, 2004) (applying case law in ruling on allegations of torture), available at http://www.echr.coe.int.

"1 See generally LAWYERS COMM. FOR HUMAN RIGHTS, ASSESSING THE NEW NORMAL: LIBERTY AND SECURITY FOR THE POST-SEPTEMBER 11 UNITED STATES (2003) (arguing that executive orders have bypassed independent judicial review and thus violate the principles of the rule of law); William F. Schulz, TAINTEd LegaCy: 9/11 AND THE RUIN OF HUMAN RIGHTS (2003) (maintaining that current international human rights policy is sufficient protection of our security and need not be violated as it has been during the war on terror); Neal K. Katyal \& Laurence H. Tribe, Waging War, Deciding Guilt: Trying the Military Tribunals, 111 YALE L.J. 1259 (2002) (arguing that the President does not have the power to unilaterally establish military tribunals because the Constitution prohibits the executive from defining a state of war without a congressional declaration); Anthony Lewis, Civil Liberties in a Time of Terror, 2003 WIS. L. REV. 257 (maintaining that the executive power should not override constitutional rights in the undeclared war on terror); Kenneth Roth, Human Rights, the Bush Administration, and the Fight Against Terrorism: The Need for a Positive Vision, in LOST LIBERTIES: AshCroft and the Assault on Personal Freedom 237 (Cynthia Brown ed., 2003) (arguing that the United States' war on terrorism ignores and violates internationally accepted human rights protections); David Glazier, Note, Kangaroo Court or Competent 
almost certainly continue to have) a disastrous effect on basic rights and vulnerable populations. ${ }^{12}$ Many in these communities have insisted, for instance, that the law of armed conflict should be interpreted in a strict and formalistic manner when it comes to evaluating U.S. actions in the "war on terror," (including Amnesty International) have asserted that since al Qaeda is neither a state nor a domestic insurgent group, the law of armed conflict does not apply at all to the U.S. struggle against terrorism, ${ }^{14}$ which should be governed instead by the principles of domestic and international criminal law.

It is somewhat ironic for any in the human rights law community to insist on a rigid and traditional reading of the law of armed conflict when it comes to the war on terror, since in many other contexts the human rights community has appropriately been at the forefront of calls for progressive and flexible interpretations of international law. ${ }^{15}$

Tribunal?: Judging the 21st Century Military Commission, 89 VA. L. REV. 2005 (2003) (arguing that modern military commissions should adhere to statutory court-martial procedures).

${ }^{12}$ See Roth, supra note 11 , at 244 (noting that the Bush administration's aggressive stance in the war on terrorism threatens personal liberties).

${ }^{13}$ See, e.g., Gabor Rona, Interesting Times for International Humanitarian Law: Challenges from the "War on Terror," 27 FLETCHER F. WORLD AFF. 55, 56-58 (2003) (maintaining the importance of existing limits to humanitarian law and its application to the war on terror). But see Kenneth Roth, The Law of War in the War on Terror, 83 ForeIgN AFF., Jan.-Feb. 2004, at 2, 2-3 (offering a much more nuanced account of the applicability of the international law of armed conflict to the war on terror).

${ }^{14}$ See, e.g., Amnesty InT'l, Yemen: The Rule of LAW Sidelined in the Name of SECURITY 23 (2003) ("Under existing international humanitarian law, it is not possible to have an international armed conflict between a state on the one hand and a nonstate actor on the other, should the armed group not form part of the armed forces of a Party to the Geneva Conventions."), available at http://web.amnesty.org/ library/pdf/mde310062003english/\$file/mde3100603.pdf; see also Michael Ratner, Moving Away from the Rule of Law: Military Tribunals, Executive Detentions and Torture, 24 CARDOZO L. REV. 1513, 1516 (2003) ("I question whether it is legal or appropriate that nonstate actors be tried by a military order in front of a military tribunal when it is apparent that they cannot commit violations of the laws of war, other than in a civil war situation."); John C. Yoo \& James C. Ho, The Status of Terrorists, 44 VA. J. INT'L L. 207, 208 (2003) (noting the argument that "the September 11 attacks were not the initiation of an armed conflict, but merely the latest eruption of a persistent social problem," and should thus be subject to rules of criminal law, much like the war on drugs; or if the laws of war are to apply, then members of al Qaeda and the Taliban must be treated as "lawful belligerents" with the according rights and privileges).

${ }^{15}$ The human rights community has urged flexible interpretations of international law when such flexibility is necessary to address gender-based crimes, economic and social rights claims, children's rights, and similar issues. Human rights advocates have also used such arguments in, to name just a few examples, justifying the concept of "universal jurisdiction," lobbying for the International Criminal Court, and urging 
In the longer run, shifting from one interpretive methodology to another based on the likely results of different methodologies is both unprincipled and likely to be self-defeating, as it is difficult to simultaneously argue, for instance, that the law of armed conflict should be construed narrowly when the goal is reining in U.S. government actions, but flexibly when the goal is holding nonstate actors accountable for crimes against humanity or ending impunity for gender-based crimes committed during armed conflicts. ${ }^{16}$

The effort to insist on the viability of the customary distinctions drawn by the laws of armed conflict is also, increasingly, a rearguard action. The erosion of boundaries is an inescapable social fact, and this Article asserts that it needs to be candidly acknowledged and addressed, rather than ignored or denied.

To say that the erosion of traditional legal boundaries is an inescapable fact is not to minimize the degree to which it is nonetheless genuinely cause for alarm, however; rights advocates are justifiably concerned about the consequences of this boundary erosion. The existence of reasonably clear boundaries between conflict and nonconflict, combatants and noncombatants, and "lawful" and "unlawful" belligerents is what allows us to determine which legal rules apply in different situations, and, even more critically, allows us to identify people and rights meriting protection. As traditional categories lose their logical underpinnings, we are entering a new era: the era of War Everywhere. ${ }^{17}$ It is an era in which the legal rules that were designed

U.S. courts to accept expansive interpretations on "the law of nations" in the context of the Alien Tort Claims Act, 1 Stat. 73, 77 (1789) (codified as amended at 28 U.S.C. \& $1350(2000))$. See generally M. Cherif Bassiouni, Universal Jurisdiction for International Crimes: Historical Perspectives and Contemporary Practice, 42 VA. J. INT'L L. 81 (2001) (analyzing the history of universal jurisdiction and its current practice in the international community).

${ }^{16}$ Of course, there is another irony here as well. The Bush administration has in most contexts insisted that international law is not directly applicable in U.S. courts. See, e.g., Brief of the United States in Support of Petitioner at 24, Sosa v. AlvarezMachain, 124 S. Ct. 2739 (2004) (No. 03-339) (arguing that sources of customary international law do not confer a cause of action in a U.S. court). In the context of several recent cases, however, the government has essentially asserted the opposite, arguing that when the government says that an armed conflict exists and designates someone an "enemy combatant," the international law of armed conflict immediately displaces constitutional law in U.S. courts. See Brief for the Petitioner at 27-28, Rumsfeld v. Padilla, 124 S. Ct. 2711 (2004) (No. 03-1027) (arguing that captured enemy combatants are subject only to international "laws of war"); Brief for Respondents at 9-11, Hamdi v. Rumsfeld, 124 S. Ct. 2633 (2004) (No. 03-6696) (arguing that holding enemy combatants under law of war does not violate the U.S. Constitution).

${ }^{17}$ The title of this Article was suggested by comments given by Mary Ellen O'Connell at a conference on "Globalization, Democracy, and Regulation: The Inter- 
to protect basic rights and vulnerable groups have lost much of their analytical force, and thus, too often, their practical force.

The erosion of clear boundaries in some areas of the law also leads to a slippery slope, allowing the disingenuous to assert that there is also blurriness even in areas of the law that remain both relevant and clear. Thus, lawyers for the Bush administration went from the legitimate conclusion that the Geneva Conventions cannot easily be applied to many modern conflicts, to the disingenuous and flawed conclusion that there were therefore no legal constraints at all on U.S. interrogation practices. ${ }^{18}$ In fact, regardless of whether or not the Geneva Conventions apply to a given conflict, and regardless of whether

national Architecture of Law in the Twenty-First Century," held by Princeton's Law and Public Affairs Program on May 29, 2003. Discussing the missile attack on al Qaeda suspects in Yemen, O'Connell noted the danger that the "war on terror" becomes "war everywhere." Additionally, in a prescient book, two Chinese military officers discuss the social and technological changes of recent conflicts and dub the "new" warfare "unrestricted warfare." They warn that "this kind of war means that all means will be in readiness . . . and the battlefield will be everywhere. It means that weapons and technology can be superimposed at will, it means that all the boundaries lying between the two worlds of war and non-war, of military and non-military, will be totally destroyed ...." QIAO LIANG \& WANG XIANGSUI, UNRESTRICTED WARFARE 12 (1999) at http://www.iwar.org.uk/iwar/resources/china/iw/unrestricted-warfare.pdf.

${ }^{18}$ In January 2002, White House counsel Alberto Gonzales wrote in a memo to President Bush that the Geneva Conventions are "obsolete" and should be declared inapplicable to Taliban and al Qaeda detainees held at Guantanamo. See John Barry et al., Special Report, NEwsweEk, May 24, 2004, at 28, 31 (quoting the Gonzales memo). This memo, and similar memos that followed from the DOJ's Office of the Legal Counsel and from the Pentagon, appear to have played a role in giving the green light for Pentagon approval of a range of harsh interrogation techniques, including hooding, sleep deprivation, use of dogs, sensory deprivation, nudity, and the placement of prisoners in painful positions for extended periods. See Hearing on Iraqi Prisoner Abuse Before the S. Armed Servs. Comm., 108th Cong. (May 11, 2004), 2004 WL 1053885 (testimony of Stephen Cambone, Undersecretary of Defense for Intelligence) (stating that the use of harsh interrogation techniques was approved at the command level in Iraq).

When photos of egregious abuses at abu Ghraib prison in Iraq caused a worldwide scandal, U.S. interrogation practices came under increasing scrutiny, and many commentators (including the author) linked the abu Ghraib abuses to the Bush administration's conviction that much international law is outmoded and irrelevant. See, e.g., Rosa Ehrenreich Brooks, Opinion, A Climate that Nurtures Torture, L.A. TIMES, May 9, 2004, at M3 ("What happened was the predictable result of the Bush administration's 'anything goes' approach to national security."). More recent White House statements have backed away from the extreme positions expressed in a number of the administration's earlier legal memos. See, e.g., Lieutenant General Anthony Jones, Special Defense Department Briefing on Results of Investigation of Military Intelligence Activities at Abu Ghraib Prison Facility (Aug. 25, 2004) (transcript available at http://defenselink.mil/transcripts/2004/tr20040825-1224.html) (stating that the doctrine and policies of the military are consistent with the Geneva Conventions and that this has been reinforced in recent memos). 
or not a particular detainee is entitled to the protections of the Geneva Conventions, international law and U.S. treaty commitments prohibit the use of torture and other forms of cruel, inhuman, or degrading treatment of detainees-and there can be little doubt that many of the interrogation practices authorized by the Pentagon constitute torture or cruel, inhuman, and degrading treatment. ${ }^{19}$ In practice, then, the breakdown of clear boundaries in some areas of the law also dangerously undermines the efficacy of other legal rules. ${ }^{20}$

${ }^{19}$ See supra note 10 (discussing international legal standards governing humane treatment of detainees). Many of the Pentagon's approved interrogation techniques also run afoul of accepted American legal standards. In a letter to Senator Patrick Leahy, dated June 25, 2003, Defense Department General Counsel William Haynes acknowledged that the Convention Against Torture not only requires the United States not to engage in torture, but also requires the United States to "prevent other acts of cruel, inhuman or degrading treatment or punishment which do not amount to torture." Letter from William J. Haynes II, General Counsel of the Department of Defense, to Senator Patrick J. Leahy (June 25, 2003) (quoting Convention Against Torture, supra note 10 , art. 16, S. TREATY DOC. No. 100-20 at 23, 1465 U.N.T.S. at 116), available at http://www.hrw.org/press/2003/06/letter-to-leahy.pdf. Haynes noted that a U.S. reservation to the Convention Against Torture states that the United States understands "cruel, inhuman or degrading treatment or punishment" to mean those acts that are "prohibited by the Fifth, Eighth, and/or Fourteenth Amendments to the Constitution of the United States." Id. (quoting S. TREATY DOC. NO. 100-20 at 15-16). Haynes confirmed that "United States policy is to treat all detainees and conduct all interrogations, wherever they may occur, in a manner consistent with this commitment." Id. (emphasis added). There is a large body of U.S. case law interpreting the due process and cruel and unusual punishment provisions of the Fifth, Eighth, and Fourteenth Amendments, and it is quite clear that numerous interrogation techniques currently approved by the Department of Defense would violate those constitutional prohibitions if used against U.S. suspects or prisoners. See, e.g., Hope v. Pelzer, 536 U.S. 730, 741 (2002) (holding that the plaintiff's allegations of being handcuffed to a hitching post, if true, established an Eighth Amendment violation); Clewis v. Texas, 386 U.S. 707, 707 (1967) (finding a Fourteenth Amendment violation in the taking of an involuntary confession; Malinski v. New York, 324 U.S. 401, 404 (1945) (noting that the introduction of an involuntary confession as evidence can violate Fourteenth Amendment due process).

${ }^{20}$ It is important to distinguish between plausible readings of the Geneva Conventions and implausible readings. Throughout this Article, I argue that various U.S. government assertions-such as those relating to the government's ability to designate U.S. citizens as "enemy combatants," those relating to the distinction between lawful and unlawful combatants, etc.- -are legally plausible, although they are troubling from a policy perspective and from the viewpoint of ensuring government accountability and protecting fundamental rights. That is, the changed nature of modern security threats genuinely erodes the traditional distinctions between war and peace, combatants and noncombatants, etc., and creates real ambiguity about the most appropriate legal paradigm to apply in various current situtations.

Bush administration efforts to justify interrogation techniques such as hooding, sleep deprivation, use of dogs, sensory deprivation, nudity, and the placement of prisoners in painful positions for extended periods present a different issue altogether. Regardless of the applicable legal framework, the international legal standards govern- 
In the long run, the old categories and rules need to be replaced by a radically different system that better reflects the changed nature of twenty-first century conflict and threat. What such a radically different system would look like is difficult to say, and the world community is unlikely to develop a consensus around such a new system anytime soon. This Article suggests, nonetheless, that international human rights law provides some benchmarks for evaluating U.S. government actions in the war on terror, and ultimately for developing a new analytical framework that can successfully balance the need to respond to new kinds of security threats with the equally important need to preserve and protect basic human rights.

Unlike domestic U.S. law and the law of armed conflict, international human rights law applies to all people at all times, regardless of citizenship, location, or status. ${ }^{21}$ Although human rights law permits limited derogation in times of emergency, it also outlines core rights that cannot be eliminated regardless of the nature of the threat or the existence or nonexistence of an armed conflict. ${ }^{22}$ Applying the stan-

ing minimally humane treatment of detainees clearly prohibit most of the practices authorized by the Pentagon, as do U.S. constitutional norms and U.S. understandings of our legal obligations under the Torture Convention. See supra notes 10, 18-19.

Thus, although at first blush it might seem that the erosion of traditional legal boundaries creates an environment in which harsh interrogation techniques could be viewed as legitimate, this is not the case. A general U.S. government feeling that the Geneva Conventions are ill-suited to modern conflicts almost certainly contributed to an overall atmosphere in which even legal rules that remain clear and relevant were seen as somehow "optional," but this view rests on a forced and disingenuous reading of both international and U.S. law.

My concern in this Article is to discuss those aspects of the law of armed conflict that have become genuinely ambiguous in light of changed external circumstances. Since the prohibitions on torture and cruel or inhumane treatment remain quite unambiguous, despite some Bush administration assertions to the contrary, this Article will not devote significant time to discussing the debate about interrogation practices.

${ }^{21}$ See, e.g., INT'L COMM. OF THE RED CROSS (ICRC), INTERNATIONAL HUMANITARIAN LAW AND INTERNATIONAL HUMAN RIGHTS LAW: SIMILARITIES AND DIFFERFNCES 1 (2003) ("Human rights are inherent entitlements which belong to every person as a consequence of being human."), available at http://www.icrc.org/web/eng/ siteeng0.nsf/htmlall/57JR8L/\$FILE/IHL_and_IHRL.pdf?OpenElement (last visited Oct. 18, 2004); see also Derek Jinks, International Human Rights Law and the War on Terrorism, 31 DENV. J. INT'L L. \& POL'Y 58, 65 (2002) ("Some rights are not subject to derogation even in times of public emergency.").

${ }_{22}$ See, e.g., Legality of the Threat or Use of Nuclear Weapons, 1996 I.C.J. 226, 240 (July 8) (noting that "the protection of the International Covenant of Civil and Political Rights does not cease in times of war"); see also The Julia, 12 U.S. (8 Cranch) 181, 193 (1814) (noting that "rights of humanity" pertain in time of war); Jordan J. Paust, Judicial Power to Determine the Status and Rights of Persons Detained Without Trial, 44 HARv. INT'L L.J. 503, 505 (2003) ("Under international law, human rights standards that are both treaty-based and part of customary international law [are] applicable in times of 
dards of international human rights law in both domestic and international contexts would not solve all the problems created by the increasing irrelevance of other legal frameworks, but it would provide at least a basic floor, a minimum set of standards by which international and domestic governmental actions could be evaluated. U.S. courts are free to make use of applicable international human rights law, though they rarely do so; this Article urges U.S. courts to make greater recourse to international human rights law in evaluating legal challenges to post-September 11 government action. International human rights law and norms can also be used as a political benchmark for evaluating uses of force by the U.S. in the international context. Human rights norms also can, and should, be the starting point for developing a new legal framework in which to view state responses to new and emerging security threats.

A great deal has already been written about ambiguities and gaps in the law of armed conflict, ${ }^{23}$ about how the law of armed conflict should (or should not) be applied to the events of September 11 and to terrorism in general, ${ }^{24}$ and about the threats to human rights and

both peace and war ....").

${ }^{23}$ See, e.g., M. Cherif Bassiouni, The Normative Framework of International Humanitarian Law: Overlaps, Gaps and Ambiguities, 8 TranSNAT'L L. \& CONTEMP. Probs. 199, 202 (1998) (attributing gaps and ambiguities in the law of armed conflict to "the haphazard evolution of international criminal law" and lack of governmental desire to close gaps); see $\rightarrow$ W. Michael Reisman \& James Silk, Which Law Applies to the Afghan Conflict?, 82 AM. J. INT'L L. 459, 466 (1988) (noting the ambiguous legal situation of conflicts between opposition forces and a state intervening on behalf of the established government); James G. Stewart, Towards a Single Definition of Armed Conflict in Intermational Humanitarian Law: A Critique of Internationalized Amed Conflict, 85 INT'L REV. RED CROSs 313, 314 (2003) (calling for a single law of armed conflict to remedy current failures in the law when conflicts contain both international and noninternational elements).

${ }^{24}$ See, e.g., Jordan J. Paust, War and Enemy Status After 9/11: Attacks on the Laws of War, 28 YALE J. INT'L L. 325, 326 (2003) (asserting that the United States cannot be at war with al Qaeda because of international law's definition of war as involving a nationstate, belligerent, or insurgent group and defining an insurgent group as having "the semblance of a government, an organized military force, control of significant portions of territory as its own, and its own relatively stable population or base of support within a broader population"); William H. Taft IV, The Law of Armed Conflict After 9/11: Some Salient Features, 28 YALE J. INT'L L. 319, 320 (2003) ("The law of armed conflict provides the most appropriate legal framework for regulating the use of force in the war on terrorism."); Amanda Schaffer, Comment, Life, Liberty, and the Pursuit of Terrorists: An In-Depth Analysis of the Government's Right to Classify United States Citizens Suspected of Terrorism as Enemy Combatants and Try Those Enemy Combatants by Military Commission, 30 FORDHAM URB. L.J. 1465, 1466 (2003) (determining that the United States should try terrorists by military trials rather than in civilian court). 
civil liberties posed by the "war on terror." the three blind men and the elephant, ${ }^{26}$ each commentator focuses on only one or two pieces of the picture, and the larger reality goes unappreciated. This Article seeks to focus on that larger reality (the forest, rather than the trees, to shift metaphors), suggesting we entirely lack an adequate domestic or international legal paradigm for thinking about the changes brought about by the rise of global terrorism.

This is hard for many to accept, since it implies that at the moment there are few domestic or international legal constraints on the war on terror. ${ }^{27}$ Nonetheless, this Article asserts that acknowledging this is better, in the long run, than denying it. Rather than insisting on the continued validity of obsolete legal paradigms, we should take

${ }^{25}$ See Taft, supra note 24, at 321 (claiming that even if terrorists are denied POW status, they still have a right to humane treatment); see also Rudolf Dolzer, Clouds on the Horizon of Humanitarian Law?, 28 YALE J. INT'L L. 337, 338 (2003) ("In the absence of an expectation of reciprocity during armed conflict ... public support for a graceful conduct of warfare may vanish quickly."); Katyal \& Tribe, supra note 11, at 1260 (declaring the President's Order establishing military tribunals for the trial of terrorists unconstitutional); Ratner, supra note 14, at 1516 (examining whether military tribunals are outlawed by the Geneva Conventions); Roth, supra note 11, at 237 (arguing that the actions of the United States in the fight against terrorism are "putting at risk the human rights ideal").

${ }^{26}$ For one variant of this famous story, see JAMES BALDWIN, The Blind Men and the Elephant, in FifTy Famous Stories Retold 130-31 (New York, Am. Book Co. 1896), available at http://www.mainlesson.com/display.php?author=baldwin\&book=fifty\& story=blind.

There were once six blind men who stood by the road-side every day ....

It so happened one morning that an el-e-phant was driven down the road where they stood....

Of course they could not see him with their eyes; but they thought that by touching him they could learn just what kind of animal he was.

The first one happened to put his hand on the elephant's side. "Well, well!" he said, "now I know all about this beast. He is ex-act-ly like a wall."

The second felt only of the elephant's tusk. "My brother," he said, "you are mistaken. He is not at all like a wall. He is round and smooth and sharp. He is more like a spear than anything else."

The third happened to take hold of the elephant's trunk. "Both of you are wrong," he said. "Anybody who knows anything can see that this elephant is like a snake."

Then the elephant moved on, and the six blind men sat by the roadside all day, and quar-reled about him. Each believed that he knew just how the animal looked; and each called the others hard names because they did not agree with him. People who have eyes sometimes act as foolishly.

Id.

${ }^{27}$ To say that there are few legal constraints does not mean that there are no constraints at all, of course. Despite its superpower status, the U.S. government faces political, financial, and diplomatic constraints in the war on terror. 
stock of the tools international human rights law offers for evaluating and critiquing the war on terror. At the same time, we need to begin to imagine the basic contours of a new domestic and international legal paradigm, one that balances the need to respond to new security threats with the need to protect core rights. This Article seeks to begin that process.

Part I of this Article is devoted to background, briefly describing, first, the evolution and content of the law of armed conflict and the international system it presupposes. Second, it explores the parallel domestic legal assumptions embodied in what we can loosely refer to as national security law. Part II chronicles some of the recent changes that are rendering these background assumptions and categories increasingly less coherent and relevant.

Part III examines the concrete ways in which the boundaries between traditional categories have eroded, looking at various definitional boundaries (such as those between "international" and "internal" armed conflict, and between "armed conflict" and "crime"), spatial/geographical boundaries, temporal boundaries, boundaries between categories of persons, and the boundaries between "national security" matters and "purely domestic" matters as understood by U.S. courts. $^{28}$

Part IV discusses the implications of the erosion of these boundaries, and concludes that rights advocates are correct to suspect that there is much to fear. Part V suggests that international human rights law may offer a partial and interim solution to the problem. Part VI acknowledges that a more thoroughgoing reconceptualization of the law of armed conflict is necessary in the longer run, and offers some preliminary suggestions for how such a reconceptualization might proceed.

\section{BACKGROUND}

\section{A. The Law of Armed Conflict}

In peace, there's nothing so becomes a man, As modest stillness, and humility:

But when the blast of war blows in our ears, Then imitate the action of the tiger:

${ }^{28}$ As mentioned in note 20, supra, I will not spend much time discussing the debate about permissible and impermissible interrogation techniques, because I consider that a fundamentally different issue. 


\section{Stiffen the sinews, summon up the blood, Disguise fair nature with hard-favored rage; Then lend the eye a terrible aspect. ${ }^{29}$}

Efforts to control and limit warfare are almost as old as warfare itself, ${ }^{30}$ but the modern law of armed conflict has its roots in the nineteenth century, when efforts to formally codify the rules of war began in the West. ${ }^{31}$ In 1856, the Conference of Paris sought to come up with rules governing naval warfare. ${ }^{32}$ In 1863, during the American Civil War, the United States Army issued General Order No. 100, Instructions for the Government of Armies of the United States in the Field. $^{33}$ Based on the recommendations of Columbia University professor Francis Lieber, and better known as the Lieber Code, General Order No. 100 laid out basic rules concerning permissible and impermissible methods of warfare, including rules relating to the treatment of civilians. ${ }^{34}$ Also in 1863, Swiss citizen Henry Dunant founded the International Committee of the Red Cross (ICRC) "for the pur-

${ }^{29}$ WILliam SHAKESPEARE, KING HENRY V, act 3, sc. 1.

${ }^{30}$ Consider biblical injunctions to show mercy to captives or Athenian codes of military conduct. See, e.g., 2 Kings 6:21-22 ("Set food and water before them so they may eat and drink."); THE LANDMARK THUCYDIDES: A COMPREHENSIVE GUIDE TO THE PELOPONNESIAN WAR 193 (Robert B. Strassler ed., 1996). See generally MICHAEL HOWARD, WAR IN EUROPEAN HISTORY 6-7 (1976) ("By the fourteenth century the laws and limitations on the conduct of war were elaborate, much written about, and fairly uniform throughout western Christendom... [T] hey were seen less as a system of positive law or as restraints consciously dictated by humanitarianism than as a code of social behaviour.").

31 See generally Yoram Dinstein, WAR, AGgREssion AND SELF-DEFENCE (2d ed. 1994) (examining the legality of war); THE LAWS OF WAR: CONSTRAINTS ON WARFARE IN THE WLSTERN WORLD (Michael Howard et al. eds., 1994) (examining the traditions of both formal constraints on warfare and unwritten conventions as to proper military practice).

${ }^{32}$ See Michael Howard, Constraints on Warfare, in THE LAWS OF WAR, supra note 31, at 6-7 (discussing attempts to constrain warfare during the nineteenth and early twentieth centuries).

${ }^{33}$ INSTRUCTIONS FOR THE GOVERNMENT OF THE ARMIES OF THE UNITED STATES IN THE FIELd (LiEber INSTRUCTIONS), Gen. Order No. 100 (Dep't of War Apr. 24, 1863), available at http://www.yale.edu/lawweb/avalon/lieber.htm (Iast visited Nov. 25, 2004).

${ }^{34}$ See id. art. 19 ("Commanders, whenever admissible, inform the enemy of their intention to bombard a place, so that the noncombatants, and especially the women and children, may be removed before the bombardment commences."); id. art. 22 ("The principle has been more and more acknowledged that the unarmed citizen is to be spared in person, property, and honor as much as the exigencies of war will admit."); $i d$. art. 25 (" $[\mathrm{P}]$ rotection of the inoffensive citizen of the hostile country is the rule ...."). 
pose of having care given to the wounded in wartime by zealous, devoted and thoroughly qualified volunteers." ${ }^{35}$ Dunant also urged the leaders of European states to develop "some international principle, sanctioned by a convention and inviolate in character, which, once agreed upon and ratified, might constitute the basis for societies for the relief of the wounded in the different European countries." ${ }^{36}$ In 1864, Dunant's efforts were rewarded; ten European states ratified the Geneva Convention for the Amelioration of the Condition of the Wounded in Armies in the Field (First Geneva Convention). ${ }^{37}$

Efforts to constrain armed conflict continued; in 1899 and 1907, international peace conferences at The Hague led to the drafting and later entry into force of the various Hague Conventions on the laws and customs of war, ${ }^{38}$ and in the interwar period, the Kellogg-Briand Pact between the United States and fourteen other nations made it illegal to have "recourse to war for the solution of international controversies." In the wake of World War II, the 1945 U.N. Charter cemented the prohibition on waging aggressive war. The Charter laid out the basic conditions in which states may resort to the use of force, declaring that "[a]ll Members shall settle their international disputes by peaceful means .... [and] refrain in their international relations from the threat or use of force against the territorial integrity or political independence of any state." ${ }^{40}$ The four Geneva Conventions of 1949 further rationalized and codified customary and treaty-based norms relating to armed conflict, outlining the rules applicable to civilians, prisoners of war, and wounded and sick members of armed forces. $^{41}$

${ }^{35}$ From the Battle of Sol Ferino to the First Geneva Convention and Beyond: Founding and Early Years of the ICRC (1863-1914), ICRC (June 4, 1998), available at http:// www.icrc.org/web/eng/siteeng0.nsf/htmlall/57JNVP (last visited Sept. 16, 2004).

${ }^{36} I d$.

${ }^{37}$ Id.; see also THE LAWS OF WAR, supra note 31, at 6 (discussing the signing of the First Geneva Convention and the events leading up to it).

${ }^{38}$ Convention Between the United States and Other Powers Respecting the Laws and Customs of War on Land, Oct. 18, 1907, 36 Stat. 2277 [hereinafter Hague Convention]; Regulations Respecting the Laws and Customs of War on Land, Oct. 18, 1907, 36 Stat. 2295 [hereinafter Hague Regulations].

${ }^{39}$ Treaty Between the United States and Other Powers Providing for the Renunciation of War as an Instrument of National Policy (Kellogg-Briand Pact), Aug. 27, 1928, art. I, 46 Stat. 2343, 2345.

${ }^{40}$ U.N. CHARTER, art. 2, paras. 3-4.

${ }^{41} 1949$ Geneva Conventions, supra note 10,6 U.S.T. at 3114, 3217, 3316, 3517, 75 U.N.T.S. at $31,85,135,287$. The full texts of the four Geneva Conventions are available online at http://www.icrc.org/web/eng/siteeng0.nsf/iwplist133/578438309B69 EB59C1256EA90026A03C. 
This process of seeking to constrain armed conflict has continued into the present time. In 1974, the U.N. General Assembly adopted a definition of state "aggression" for the first time. ${ }^{42}$ In 1977, an international conference led to two Additional Protocols to the Geneva Conventions, both of which have been widely ratified. ${ }^{43}$ More recently, the jurisprudence of the ad hoc international criminal tribunals for Yugoslavia and Rwanda have breathed new life into our understanding of war crimes and crimes against humanity, ${ }^{44}$ as has the process of negotiating the statute governing the new International Criminal Court. ${ }^{45}$ As recently as 2002, a new Optional Protocol to the Convention on the Rights of the Child entered into force, enhancing international legal mechanisms designed to protect children during armed conflicts. ${ }^{46}$

${ }^{42}$ G.A. Res. 3314, U.N. GAOR, 29th Sess., Supp. No. 31, at 143, U.N. Doc. A/9631 (1974) ("Aggression is the use of armed force by a State against the sovereignty, territorial integrity or political independence of another State, or in any other manner inconsistent with the Charter of the United Nations ....").

${ }^{43}$ See Protocol Additional to the Geneva Conventions of 12 August 1949, and Relating to the Protection of Victims of International Armed Conflicts, June 8, 1977, 1125 U.N.T.S. 4 [hereinafter Protocol I] (setting forth protocols for the treatment of civilians and combatants in situations of armed conflict); Protocol Additional to the Geneva Conventions of 12 August 1949, and Relating to the Protection of Victims of NonInternational Armed Conflicts, June 8, 1977, 1125 U.N.T.S. 609 [hereinafter Protocol II] (extending the human rights guarantees of Protocol I to noninternational armed conflicts). More than three-fourths of all nation-states have ratified these Additional Protocols. The United States is one of the few western nations that has not ratified them, but the United States accepts most provisions of the Additional Protocols as binding norms of customary international law, and/or consistent with U.S. practice. See INT'L \& OpERATIONAL LAW DEP'T, THE JUDGE ADVOCATE GENERAL'S SCH., OPERATIONAL LAW HANDBOOK 7-13 (Jeanne M. Meyer \& Brian J. Bill eds., 2002), available at https://www.jagcnet.army.mil/JAGCNETInternet/Homepages/AC/CLAMOPublic. nsf /0/1 af4860452f962c085256a490049856f/\$FILE/Master\%20Document.pdf, for a brief description of those aspects of the Additional Protocols considered binding by the United States.

${ }^{44}$ For a general overview of tribunal case law, see HUMAN RIGHTS WATCH, GENOCIDE, WAR CRIMES AND CRIMES AGAINST HUMANITY: TOPICAL DIGESTS OF THE GASE LAW OF TIIE INTERNATIONAL CRIMINAL TRIBUNAL FOR RWANDA AND THE INTERNATIONAI. CRIMINAL TRIBUNAL FOR THE FORMER YUGOSLAVIA (2004), available at http://www.hrw.org/reports/2004/ij.

${ }^{45}$ See Rome Statute of the International Criminal Court, July 17, 1998, 2187 U.N.T.S. 90 [hereinafter Rome Statute] (establishing an International Criminal Court having jurisdiction over genocide and other crimes against humanity), available at http://www.un.org/law/icc/statute/romefra.htm .

${ }^{46}$ Optional Protocol to the Convention on the Rights of the Child on the Involvement of Children in Armed Conflict, S. TREATY DOC. No. 106-37 (2000), 39 I.L.M. 1285 (entered intro force Feb. 12, 2002), available at http://www.unhchr.ch/ $\mathrm{html} / \mathrm{menu} 2 / 6 / \mathrm{crc} /$ treaties/opac.htm. The United States has signed and ratified this agreement. 
These various treaties have been widely ratified, ${ }^{47}$ and to a significant extent, core provisions of these treaties have been accepted as customary international law ${ }^{48}$ that binds even those states that are not parties to the treaties, and that also binds nonstate actors (such as insurgent groups), which lack the legal capacity to ratify treaties. ${ }^{49}$ Thus, for example, Common Article 3 of the Geneva Conventions, which outlines the minimum protections that must be afforded to noncombatants, is now generally accepted as universally binding on all parties to all armed conflicts.

The law of armed conflict governs many different aspects of armed conflicts, but it mainly consists of those rules traditionally referred to as jus in bello, "law in war," which relate to the manner in which armed conflict may proceed. Jus in bello consists of rules relating to proper and improper kinds of weapons and military tactics, rules relating to the treatment of prisoners of war and civilians, and so on. ${ }^{51}$ (Jus in bello is contrasted with jus ad bellum, the laws relating to

${ }^{47}$ Of the 191 member states of the United Nations, all 191 are party to the Geneva Conventions of 1949, 162 are party to Additional Protocol I, and 157 are party to Additional Protocol II. States Party to the Geneva Conventions and Their Additional Protocols, ICRC (Jan. 6, 2004), available at http://www.icrc.org/eng/party_gc.

48 For a general discussion of customary international law, see Statute of the International Court of Justice, June 26, 1945, art. 38, 59 Stat. 1031, 1060 (defining what international law should be applied by the International Court of Justice); RESTATEMENT (THIRD) OF THE FOREIGN RELATIONS LAW OF THE UNITED STATES (1987) [hereinafter FOREIGN RELATIONS LAW] (covering international law as it relates to the United States, which stems largely from customary international law); MARK E. VILLIGER, CUSTOMARY INTERNATIONAL LAW AND TREATIES (1985) (providing general discussion of customary international law).

${ }^{49}$ See FOREIGN RELATIONS LAW, supra note 48, at 16-21 (explaining that parties may be bound by a rule of customary law that they did not participate in making).

${ }^{50}$ See Francoise Bouchet-Saulnier, The Practical Guide to Humanitarian LAW 109 (Laura Brau trans. \& ed., 2002) ("[T] he Conventions clearly establish that these are minimum norms to be respected in all situations of conflict."); see also Military and Paramilitary Activities (Nicar. v. U.S.), 1986 I.C.J. 14 (June 27) (judging the United States according to the general principles of international law, and binding it to refrain from encouraging groups engaged in conflicts involving violations of Common Article 3); Prosecutor v. Tadic, 105 I.L.R. 419 (Int'l Crim. Trib. for the Former Yugoslavia 1995) (finding jurisdiction to try a Serbian soldier for crimes against humanity in violation of Common Article 3 of the Geneva Conventions); INTERNATIONAL Criminal LAW 692-93, 695 (Jordan J. Paust et al. eds, 2d ed. 2000) (discussing the legal precedent that makes Common Article 3 a definitive part of customary international law).

Good general books on the law of armed conflict include BOUCHET-SAULNIER, supra note 50 (explaining the rights, definitions, and relevant legal instruments that constitute humanitarian law); INGRID DETTER, THE LAW OF WAR (2d ed. 2000) (exploring the legal context of modem warfare, including the roles of transnational organizations); DINSTEIN, supra note 31 (analyzing the concepts of war, aggression, and self- 
when it is proper to resort to armed conflict, a question now governed mainly by the U.N. Charter. Some commentators consider applicable U.N. Charter provisions part of the law of armed conflict, broadly conceived, while others regard this as outside of the laws of armed conflict. $^{52}$

It is beyond the scope of this Article to summarize the law of armed conflict, but it is important to note a few key principles and distinctions, some of which are probably familiar even to laypersons, others of which are likely unfamiliar to nonspecialists. To begin with, the law of armed conflict accepts that certain behaviors that are illegal and abhorrent in time of peace are both permissible and desirable in time of war. ${ }^{53}$ Most obviously, the purposeful killing of other humans is considered morally abhorrent in peacetime, but in time of war soldiers are not only permitted, but required, to try to incapacitate members of enemy forces, if necessary by killing them.

The principle of "combatant immunity" flows from the disconnect between appropriate peacetime behavior and appropriate wartime behavior. In peacetime, the willful killing of another human would normally lead to prosecution, trial, and possibly conviction for the crime of murder. During and after wars, however, soldiers cannot be prosecuted for killing enemy combatants; their deadly violence is legally immunized. $^{54}$ The same goes for numerous other forms of violence: the deliberate destruction or appropriation of public or private property is normally punishable in time of peace, but generally permissible in time of war. ${ }^{55}$ As a result, the law of armed conflict provides that combatants taken prisoner by opposing forces may be detained until the cessation of hostilities, but they may not be subject to punishment by opposing forces for their legitimate wartime acts, and they must be released and repatriated when hostilities end. ${ }^{56}$

defense in light of the transnational political changes that have occurred since the end of the Cold War).

See DINSTEIN, supra note 31, at 71 (explaining the position of Pompe, Anzilotti, and other exponents of the extralegality of war, who believe that "law cannot say when, but only how, war is to be waged").

See Bouchet-SAUlnitr, supra note 50, at 50 ("As long as [combatants'] use of force is in conformity with the provisions of the laws of war, they may not be subject to criminal pursuit.").

54 Id.; see also INT'L \& OPERATIONAL LAW DEP'T, supra note 43, at 12 (defining the conduct of hostilities during wartime).

5.5 INT'L \& OPERATIONAL LAW DEP'T, supra note 43, at 16-17 (authorizing the "destruction, capture or neutralization" of property "if it offers a definite military advantage").

See Translation of the Draft of an International Declaration Concerning the 
Of course, violence in wartime is only immunized to the extent that it is otherwise in accordance with the law of armed conflict. The law of armed conflict only offers benefits to those who play by the rules. Thus, the laws of armed conflict distinguish between violence that is justified by military necessity and militarily unjustifiable violence, and also between violence that is directed properly against enemy combatants and violence that is improperly directed against "protected persons," a category that includes both civilians and enemy combatants who are wounded, sick, or who have been taken prisoner. $^{57}$

To put this in the terms used by the law of armed conflict, military violence must seek to avoid "unnecessary" suffering, and violence must be in accordance with the principles of proportionality and discrimination, ${ }^{58}$ or else it is not immunized. The principle of proportionality requires that "[1] oss of life and damage to property incidental to attacks must not be excessive in relation to the concrete and direct military advantage expected to be gained"; the principle of discrimination requires that military violence must "distinguish between combatants and noncombatants; military objectives and protected people/protected places." ${ }^{, 59}$

Military actions not in accordance with these basic principles lack immunity, and military officials who order or carry out acts of excessive and unnecessary violence or attacks on protected persons and

Laws and Customs of War adopted by the Conference of Brussels, 27th August, 1874, art. 9 (citing the four conditions armed forces must meet in order for their members to be treated as a combatants: (1) "[t]hat they have at their head a person responsible for his subordinates"; (2) "[t] hat they wear some fixed distinctive badge recognizable at a distance"; (3) "[ $\mathrm{t}]$ hat they carry arms openly"; and (4) "[t]hat in their operations they conform to the laws and customs of war."), reprinted in A. PEARCE HIGGINS, THE Hague Peace Conferences and Other International Conferences Concerning THE LAWS AND USAGES OF WAR 274 (1909); see also United States v. Lindh, 212 F. Supp. 2d 541, $557 \&$ n.34 (E.D. Va. 2002) (noting that these criteria were "established under customary international law" and "were first codified in large part in the Brussels Declaration of $1874 "$ ).

${ }^{57}$ See, e.g., INT'L \& OPERATIONAL LAW DEP'T, supra note 43, at 12 ("Among others, non-combatants include civilians, medical personnel, chaplains, and those out of combat-including prisoners of war and the wounded and sick."). See generally Goldman \& Tittemore, supra note 7, at 2-5 (tracing the historical and legal distinctions between privileged and unprivileged combatant status in customary and conventional international law).

${ }_{58}^{8}$ Sometimes the principle of discrimination is also called the principle of distinction. See INT'L \& OPERATIONAL LAW DEP'T, supra note 43, at 10 ("[The principle of distinction] requires that combatants be distinguished from non-combatants, and that military objectives be distinguished from property or protected places.").

Id. at 31 . 
places may be subject to later prosecutions for war crimes. ${ }^{60}$ Combatants whose conduct violates these basic principles or otherwise fails to comply with the law of armed conflict may be tried and punished during or after the armed conflict if they are captured by opposing forces; they can be dubbed "unlawful combatants" by opposing forces, and are not entitled to the protections and immunities given to "prisoners of war," who are "lawful combatants."

The United States is a party to nearly all of the treaties that together constitute the international law of armed conflict, ${ }^{62}$ and for the most part the international law of armed conflict is reflected in U.S.

${ }^{60}$ The Rome Statute of the International Criminal Court defines war crimes as: (a) Grave breaches of the Geneva Conventions of 12 August 1949, namely, any of the following acts against persons or property protected under the provisions of the relevant Geneva Convention [or] (b) Other serious violations of the laws and customs applicable in international armed conflict, within the established framework of international law, namely, any of the following acts: ... Intentionally launching an attack in the knowledge that such attack will cause incidental loss of life or injury to civilians or damage to civilian objects or widespread, long-term and severe damage to the natural environment which would be clearly excessive in relation to the concrete and direct overall military advantage anticipated; [or a] ttacking or bombarding, by whatever means, towns, villages, dwellings or buildings which are undefended and which are not military objectives.

Rome Statute, supra note 45 , art. 8.

'6l For example:

As early as July 2002, the federal district court judge in [the case of John Walker Lindh] had ruled that Lindh, a U.S. citizen who had taken up arms with the Taliban, could not invoke the protections of the Geneva Conventions by arguing that he was a lawful combatant-a soldier-fighting a war on the side of the Taliban.

Wilson, supra note 6 , at 5 . Goldman \& Tittemore state:

An "unprivileged" or "unlawful" combatant refers to a person who does not have the combatant's privilege, but nevertheless directly or actively participates in hostilities. Such unlawful combatants would include civilians, certain civilians accompanying the armed forces, as well as noncombatants members of the armed forces, who, in violation of their protected status, actively engage in hostilities. These persons temporarily forfeit their immunity from direct individualized attack during such time as they assume the role of a combatant. Unlike privileged combatants, unlawful combatants upon capture can be tried and punished under municipal law for their unprivileged belligerency, even if their hostile acts complied with the laws of war.

Goldman \& Tittemore, supra note 7 , at 4 .

${ }^{62}$ The main exceptions are Additional Protocols I and II, but the United States has formally acknowledged core provisions of these as binding upon it as a matter of customary international law. See INT'L \& OPERATIONAL LAW DEP'T, supra note 43, at 11 (delineating the articles of the Protocols that the United States finds either legally binding as customary international law or acceptable practice though not legally binding). 
military regulations, the Uniform Code of Military Justice, and other federal statutes. ${ }^{69}$ To the extent that a state of armed conflict exists, both U.S. military courts and U.S. civilian courts will apply the international law of armed conflict insofar as it is reflected in U.S. law, and at times U.S. courts will also turn directly to the international law of armed conflict for the purpose of gap-filling or construing otherwise ambiguous aspects of U.S. law that derive from the law of armed conflict. ${ }^{64}$

\section{B. National Security Law}

Just as the international law of armed conflict permits certain activities in time of war that would be unlawful in time of peace, U.S. domestic law recognizes that national security imperatives may render permissible some otherwise impermissible government acts. ${ }^{65}$ To a

${ }^{63}$ See, e.g., id. at 28-29 (setting forth the jurisdictions for various violations of the law of armed conflict); see also The War Crimes Act of 1996, 18 U.S.C. $\$ 2441$ (2000) (giving U.S. federal courts jurisdiction over war crimes cases involving a U.S. national, military or nonmilitary, as either accused or victim).

${ }^{64}$ See, e.g., Ex parte Quirin, 317 U.S. 1, 27 (1942) ("From the very beginning of its history this Court has recognized and applied the law of war . . . ."); see also Hamdi v. Rumsfeld, 124. S. Ct. 2633, 2641 (2004) (looking to various international treaties to support the proposition that "[i]t is a clearly established principle of the law of war that detention may last no longer than active hostilities"); Johnson v. Eisentrager, 339 U.S. 763 (1950) (applying international law to conclude that federal courts cannot exercise jurisdiction over habeas corpus petitions filed by nonresident aliens being held overseas by the U.S. military); cf. A. Christopher Bryant \& Carl Tobias, Quirin Revisited, 2003 WIS. L. REV. 309, 363 ("In the wake of the September 11 terrorist attacks, the once relatively obscure Supreme Court decision in Ex parte Quirin has become critical to legal and constitutional debates about civil liberties' import during times of international terror.").

${ }^{65}$ See, e.g., Detention, Treatment, and Trial of Certain Non-Citizens in the War Against Terrorism, 66 Fed. Reg. 57,833 (Nov. 13, 2001) (declaring a state of armed conflict and authorizing special military tribunals to try aliens suspected of involvement in terrorist activities); see also Hamdi, 124 S. Ct. at 2647 ("[T] he law of war and the realities of combat may render such detentions [of enemy combatants] both necessary and appropriate, and our due process analysis need not blink at those realities."). Nonetheless, the Hamdi Court found the specific practice of holding U.S. citizens indefinitely to be unacceptable, although the Court was divided about the degree of due process required in such situations; cf. Padilla v. Rumsfeld, 352 F.3d 695, 714 (2d Cir. 2003) ("The Constitution envisions grave national emergencies and contemplates significant domestic abridgements of individual liberties during such times."), rev'd and remanded by 124 S. Ct. 2711 (2004). The Supreme Court reversed in Padilla on technical grounds, again leaving unanswered questions about the degree of due process owed to U.S. citizens detained on U.S. soil. See also Kennedy v. Mendoza-Martinez, 372 U.S. 144, 165-66 (1963) (holding it unconstitutional to denude an American citizen of her citizenship for leaving the United States to avoid military service during a time of war). 
significant extent this is reflected in various federal statutes that have historically permitted the executive branch certain extraordinary powers in times of national security emergencies and war. ${ }^{66}$ The most recent example of such legislation is the USA PATRIOT Act, passed by Congress in the wake of the terrorist attacks on September 11, 2001. ${ }^{67}$ The PATRIOT Act is typical of emergency legislation; it has a sunset provision, under which many of its terms expire in 2005, but in the meantime it grants vastly expanded investigatory and surveillance powers to the federal government. ${ }^{68}$

${ }^{66}$ See, e.g., National Emergencies Act (NEA) $§ 201,50$ U.S.C. $§ 1621$ (2000)) (authorizing the President to declare national emergencies); International Emergency Economic Powers Act of 1977 (IEEPA), Pub. L. No. 95-223, 91 Stat. 1626 (codified as amended at 50 U.S.C. $\$ \$ 1701-1706$ (2000)) (granting the President authority to deal with unusual or extraordinary threats); see also HAROLD RELYEA, A BRIEF HISTORY OF EMERGENCY POWERS IN THE UNITED STATES, at v (Special Comm. on Nat'l Emergencies \& Delegated Emergency Powers, Working Paper No. 36-612, 1974) (studying the use of emergency powers from the time of the Constitutional Convention through the I870s). See generally Oren Gross, Chaos and Rules: Should Responses to Violent Crises Always Be Constitutional?, 112 YALE L.J. 1011 (2003) (exploring the tendency during times of national crisis for democratic nations to race to the bottom in the protection of civil liberties).

${ }^{67}$ Uniting and Strengthening America by Providing Appropriate Tools Required to Intercept and Obstruct Terrorism Act of 2001 (USA PATRIOT Act), Pub. L. No. $107-56,115$ Stat. 272 (codified in scattered sections of $8,15,18,22,31,42,49 \& 50$ U.S.C.).

${ }^{68}$ Id. The USA PATRIOT Act creates a broadly defined new federal crime of terrorism; expands the ability of the CIA and FBI to initiate "roving" wiretaps; allows expanded intelligence and law enforcement access to personal information of individuals (including medical, school, and financial records); expands search and seizure rules; and so on. Some, but not all, of the Act's provisions will expire on December 31, 2005 if not extended by Congress. For an analysis of the legality of the USA PATRIOT Act, see Steven W. Becker, "Mirror, Mirror on the Wall. . .": Assessing the Aftermath of September 11th, 37 VAL. U. L. REv. 563 (2003), who states:

The happenings of September 11th simply provided law-enforcement and intelligence interests with the golden opportunity to (1) enact proposals that previously had been rejected or were found to be unconstitutional and (2) enlarge their own powers while concomitantly eroding the civil liberties of lawabiding American citizens. Contrary to popular perception, the USA PATRIOT Act is not directed exclusively at suspected foreign terrorists.

Id. at 592-93 (footnote omitted); see also Tracey Topper Gonzalez, Individual Rights Versus Collective Security: Assessing the Constitutionality of the USA PATRIOT Act, U. MIAMI INT'L \& COMP. L. REv., Fall 2003, at 75, 103-12 (describing surveillance methods that are being used more by the government since the Act's removal of procedural hurdles); David Hardin, Note, The Fuss over Two Small Words: The Unconstitutionality of the USA PATRIOT Act Amendments to FISA Under the Fourth Amendment, 71 GEO. WASH. L. REV. 291, 294 (2003) ("[T] he technical modification to [the 1978 Foreign Intelligence Surveillance Act by the USA PATRIOT Act] fails to provide an appropriate balance between the government's interest in national security and an individual's Fourth Amendment rights."); Shirin Sinnar, Note, Patriotic or Unconstitutional?: The Mandatory 
It is in the courts, however, that the distinction between "national security" matters and purely domestic matters has been most often elaborated, with courts fairly consistently affording greater deference to government decisions and findings when it comes to national security than when it comes to domestic affairs. ${ }^{69}$ The modern doctrine of judicial deference in national security matters is usually traced back to United States v. Curtiss-Wright, the 1936 case in which the Supreme Court famously upheld an arms embargo created by presidential executive order. In Curtiss-Wright, the Court stated that even though "the challenged delegation [of congressional power to the President], if it were confined to internal affairs, would be invalid," it may "nevertheless be sustained on the ground that its exclusive aim is to afford a remedy for a hurtful condition within foreign territory." ${ }^{70}$ Following Curtiss-Wright, the Court has generally continued to insist that " $[\mathrm{m}]$ atters intimately related to foreign policy and national security are rarely proper subjects for judicial intervention. ${ }^{, 71}$ In practice, this has often meant that courts have been less willing to protect individual rights from government interference when the stated reason for government interference is connected to national security. ${ }^{72}$

Courts have used a wide range of mechanisms that have had the effect of judicial acquiescence in otherwise problematic or impermissible government actions when these actions are taken in the name of

Detention of Aliens Under the USA PATRIOT Act, 55 STAN. L. REV. 1419, 1421 (2003) (arguing that the Act's "provisions for certification and mandatory detention contravene the Fifth Amendment's guarantee of due process of law").

${ }^{69}$ See, e.g., EPA v. Mink, 410 U.S. 73, 74 (1973) (stating that the Freedom of Information Act exempts matters "specifically required by Executive Order to be kept secret"); Youngstown Sheet \& Tube Co. v. Sawyer, 343 U.S. 579, 645 (1952) (Jackson, J., concurring) ("[The executive should be] indulge[d] the widest latitude of interpretation to sustain his exclusive function to command the instruments of national force, at least when turned against the outside world for the security of our society. But, when it is turned inward... [he] should have no such indulgence."); Chi. \& S. Air Lines, Inc. v. Waterman S.S. Corp., 333 U.S. 103, 111 (1948) (asserting that executive decisions about foreign policy are decisions that "belong in the domain of political power not subject to judicial intrusion or inquiry"); United States v. Curtiss-Wright Exp. Corp., 299 U.S. 304, 320 (1936) (stating that the President needs to be given "a degree of discretion and freedom from statutory restriction" when mainly international affairs are at issue). See generally REHNQUIST, supra note 5 (detailing historical instances of governmental infringement on civil liberties and commenting that it is during periods of declared war that the government has the greatest power to so act).

${ }^{70}$ Curtiss-Wright, 299 U.S. at 315.

71 Haig v. Agee, 453 U.S. 280, 292 (1981).

72 But cf. Youngstown, 343 U.S. at 579 (holding that the President's order to seize most of the nation's steel plants was unconstitutional despite the potential national emergency that might result from work stoppage in the industry). 
national security. At times, courts have decided cases on the merits but have also given great deference to executive judgments about national security imperatives. ${ }^{73}$ At other times, courts have applied various balancing tests, but have tended to conclude that national security considerations outweigh individual rights. ${ }^{74}$ At still other times, courts have found means of avoiding decisions on the merits by employing the "political question" doctrine or related doctrines of justiciability, standing, jurisdiction, and ripeness to allow government actions to stand.

U.S. history is replete with examples of restrictions on individual liberties that have been upheld in the context of national security imperatives but that would likely not have been permitted absent such justifications. ${ }^{76}$ During World War I, for instance, the 1917 Espionage Act and the 1918 Sedition Act placed severe limitations on First

${ }^{73}$ See, e.g., Youngstown, 343 U.S. at 645 (asserting that the "widest latitude of interpretation" is needed to sustain the President's function to command instruments of national force); Korematsu v. United States, 323 U.S. 214, 223 (1944) (justifying an exclusion order targeting persons of Japanese ancestry, based on the threat to national security). For a comparison of Korematsu to current events, see Liam Braber, Comment, Korematsu's Ghost: A Post-September 11th Analysis of Race and National Security, 47 VILL. L. REV. 451 (2002).

${ }^{74}$ Korematsu, 323 U.S. at 223-24 (finding that the segregation and detention of Japanese Americans on the West Coast during World War II was justified by military and security concerns at the time).

${ }^{75}$ See, e.g., Padilla v. Rumsfeld, 352 F.3d 695, 712 (2d Cir. 2003), rev'd and remanded by 124 S. Ct. 2711 (2004) ("[W] hether a state of armed conflict exists against an enemy to which the laws of war apply is a political question for the President, not the courts."); see also Padilla, 124 S. Ct. at 2715 ("We confront two questions: First, did Padilla properly file his habeas petition in the Southern District of New York; and second, did the President possess authority to detain Padilla militarily. We answer the threshold question in the negative and thus do not reach the second question presented."); Johnson v. Eisentrager, 339 U.S. 763, 789 (1950) ("Certainly it is not the function of the Judiciary to entertain private litigation-even by a citizen-which challenges the legality, the wisdom, or the propriety of the Commander-in-Chief in sending our armed forces abroad or to any particular region."); Norman Dorsen, Civil Liberties, $\mathrm{Na}$ tional Security and Human Rights Treaties: A Snapshot in Context, 3 U.C. DAvIS J. INT'L L. \& POL'Y 143, 146-47 (1997) (discussing different principal decisional techniques used by the Supreme Court to restrict civil liberties). But see Rasul v. Bush, 124 S. Ct. 2686 (2004) (declaring that U.S. courts have jurisdiction over Guantanamo Bay detainees).

76) See REHNQUIST, supra note 5, at 224 (noting that judicial decisions that are made after hostilities have ceased are more likely to favor civil liberties than if made while hostilities are ongoing); Dorsen, supra note 75, at 143 (noting that national security has usually been a "graveyard[] for civil liberties"); Lewis, supra note 11, at 260 (commenting on the erosion of civil liberties post-September 11); Stephen 1. Vadeck, Note, The Detention Power, 22 YaLe L. \& PoL'Y REv. 153, 154 (2004) (describing the authority to incarcerate or otherwise restrain individuals without a pre-existing statutory basis). 
Amendment rights and were used to prosecute more than 2000 people; for the most part, U.S. courts upheld the provisions of these acts in the name of national security. ${ }^{77}$ In 1940 , the Alien Registration Act was passed, with similar limitations on free expression, and was similarly upheld by the courts on national security grounds. ${ }^{78}$ The courts also upheld other more severe forms of interference with individual liberty; in Korematsu v. United States, for example, the Supreme Court notoriously declared that although the Equal Protection Clause mandates strict judicial scrutiny of race-based classifications, "military urgency" nonetheless justified the internment of Japanese Americans during World War II. ${ }^{79}$

For the most part, U.S. courts have responded in a similar manner to challenges arising out of post-9/11 government actions, although only a small number of cases have so far reached the courts. In $A C L U$ v. United States Department of Justice, the district court upheld the Justice Department's refusal to grant an ACLU Freedom of Information Act request relating to surveillance activities authorized by the USA PATRIOT Act. ${ }^{80}$ The court acknowledged that there was no apparent reason (other than the government's say-so) to determine that the information requested by the ACLU would endanger national security, but concluded that the public's legitimate interest in access to the information could not "overcome the agency's expert judgment that withholding the disputed information is authorized by the Executive Order because it is reasonably connected to the protection of national security." Studies v. United States Department of Justice, in which the Court of Appeals for the D.C. Circuit upheld the government's refusal to release the names or other details relating to individuals detained in connection with post-September 11 investigations, on the grounds that the

${ }^{77}$ Espionage Act of 1917, Pub. L. No. 65-24, 40 Stat. 217 (repealed 1948); Sedition Act of 1918, Pub. L. No. 65-150, 40 Stat. 553 (repealed 1921); see also, e.g., Abrams v. United States, 250 U.S. 616 (1919) (affirming convictions under the Espionage Act, as amended by the Sedition Act, against First Amendment challenges); Debs v. United States, 249 U.S. 211 (1919) (upholding the Espionage Act in the face of First Amendment challenges).

${ }^{78}$ Alien Registration Act of 1940 (Smith Act), Pub. L. No. 76-670, 54 Stat. 670 (repealed 1950); see also Harisiades v. Shaughnessy, 342 U.S. 580, 596 (1952) (upholding the Smith Act against challenges based on the First Amendment right of association, the Due Process Clause of the Fifth Amendment, and the prohibition of ex post facto laws).

\footnotetext{
Korematsu, 323 U.S. at 223.

${ }^{80}$ ACLU v. U.S. Dep't of Justice, 265 F. Supp. 2d 20 (D.D.C. 2003).

${ }^{81}$ Id at 30 .
} 
court "owe[s] deference" to the executive branch's judgments about the national security reasons for withholding the information. ${ }^{82}$

In North Jersey Media Group v. Ashcroft, the Third Circuit likewise upheld the government's closure of immigration proceedings to the public and the media, arguing that the national security concerns cited by the Attorney General were "credible," although somewhat speculative, and declining to "conduct a judicial inquiry into the credibility of these security concerns," given the traditional judicial "deference to Executive expertise" in national security matters.

Similarly, in Hamdi v. Rumsfeld, the Fourth Circuit upheld the indefinite detention without charge of an American citizen, Yaser Hamdi, on the government's bare assertion that Hamdi was captured by Afghan Northern Alliance forces allied with the U.S., in circumstances that proved him to be an "unlawful combatant." The Fourth Circuit upheld the government's refusal to allow Hamdi access to counsel or any mechanism to challenge the evidence on which the government determined that Hamdi was an unlawful combatant, citing the Supreme Court's traditional "great deference to the political branches when called upon to decide cases implicating sensitive matters of foreign policy, national security, or military affairs," ${ }^{25}$ and noting that "the executive is best prepared to exercise the military judgment attending the capture of alleged combatants." 86

The most recent Supreme Court Term suggests that U.S. courts will continue to struggle to determine the appropriate boundaries of executive power in times of conflict. On the one hand, the Supreme Court dealt a major blow to the Bush administration by insisting that "a state of war is not a blank check for the president when it comes to the rights of the nation's citizens," and declaring that Yaser Hamdi had to be permitted to challenge his detention. ${ }^{87}$ Similarly, in Rasul, the Court refused to accept the Bush administration's assertion that U.S. courts lacked jurisdiction to hear challenges to the detention of alleged enemy combatants at Guantanamo. ${ }^{8 \%}$ On the other hand,

${ }^{82}$ Ctr. for Nat'l Sec. Studies v. U.S. Dep't of Justice, 331 F.3d 918, 927-28 (D.C. Cir. 2003), cert. denied, 124 S. C. 1041 (2004).

${ }^{83}$ N. Jersey Media Group, Inc. v. Ashcroft, 308 F.3d 198, 219 (3d Cir. 2002).

${ }^{84}$ Hamdi v. Rumsfeld, 337 F.3d 335, $341 \mathrm{n} .1$ (4th Cir. 2003), vacated and remanded by 124 S. Ct. 2633 (2004).

${ }^{85}$ Hamdi v. Rumsfeld, 296 F.3d 278, 281 (4th Cir. 2002), vacated and remanded by 124 S. Ct. 2633 (2004).

${ }^{86} I d$. at 283.

${ }^{87}$ Hamdi, 124 S. Ct. at 2650.

${ }^{88}$ See Rasul v. Bush, 124 S. Ct. 2686 (2004) (holding that Guantanamo detainees 
however, the Court was unwilling to insist that U.S. citizens detained as suspected terrorists retain the full range of constitutional rights owed to criminal suspects; in Hamdi's case, the Court did not say specifically how Hamdi should be permitted to challenge his detention, commenting merely that "a citizen held in the United States as an enemy combatant [must] be given a meaningful opportunity to contest the factual basis for that detention before a neutral decisionmaker," 89 leaving open the possibility that Hamdi might be entitled only to a sort of "due process lite." For technical reasons, the Court also declined to decide the Padilla case on the merits, thus ducking the question of whether or not the President may lawfully designate a U.S. citizen an enemy combatant when the citizen was detained within the United States, far from a traditional field of battle. ${ }^{90}$

In effect, just as the international law of armed conflict gives combatants immunity for actions that would be unlawful in the absence of armed conflict, domestic U.S. jurisprudence implicitly gives the U.S. government immunity for many national-security-related actions that would most likely be considered inappropriate or even unconstitutional in the absence of a threat to national security. Of course, just as the law of armed conflict acknowledges that some wartime violence is so unjustifiable as to constitute war crimes, U.S. courts recognize, at least in principle, that some government actions cannot be justified even with the most compelling security imperatives. ${ }^{91}$ Courts also recognize that some government actions undertaken in the name of national security emergencies are not in fact justified by national security imperatives. ${ }^{92}$ From time to time, such considerations have led courts

had the right to have their habeas petitions heard in a U.S. federal district court).

${ }^{89}$ Hamdi, 124 S. Ct. at 2635.

${ }^{90}$ Rumsfeld v. Padilla, 124 S. Ct. 2711, 2727 (2004) (remanding to the circuit court for entry of an order of dismissal without prejudice for Padilla's failure to bring his claims in the proper distict court).

${ }_{91}$ For one of the most famous statements of this principle, see Ex parte Milligan, 71 U.S. (4 Wall.) 2 (1866), in which the Court decided that military rule cannot supercede civil courts in areas where civil courts and government remain open and unobstructed.

${ }^{92}$ See, e.g., Youngstown Sheet \& Tube Co. v. Sawyer, 343 U.S. 579, 645-46 (1952) (Jackson, J., concurring) (stating that the President does not have a constitutional grant of exclusive power to seize persons or property because they are important to the military establishment). Also consider in this regard the recent collapse of many government prosecutions of suspects in the "war on terror." See, e.g., Botched Terror Cases Are Evidence of Overzealous Prosecution, DETROIT NEws, Sept. 24, 2004, at 10A ("The collapse of the government's case in two more terrorism-related trials demonstrates again that forsaking civil liberties for the sake of staging high-profile show trials both weakens the fight against terror and the rights of all Americans."); see also Laura Parker, 
to strike down national-security-related legislation or to declare certain executive acts to be unlawful, ${ }^{93}$ just as similar considerations on the international level have sometimes led to the prosecution of soldiers or civilian leaders for war crimes-that is, for acts of violence that go beyond those permitted by the law of armed conflict. ${ }^{94}$

On the whole, however, both the international law of armed conflict and domestic national security jurisprudence grant substantial deference to claims of "military necessity" and national security necessity, and in both the international and the domestic spheres, courts have generally been reluctant to declare conduct to be unlawful when there is any plausible claim of military or national security necessity.

\section{The Assumption of Clear Boundaries}

In the international sphere, the development of binding international law applicable during armed conflicts presupposes something so obvious that many of us rarely pause to consider it: it presupposes the idea that "armed conflict" is definable and identifiable, and reasonably easily distinguishable from its opposite-nonconflict, or, in more common parlance, peace. If it is often permissible to deliberately kill large numbers of humans in times of armed conflict, even though such an act would be considered mass murder in times of peace, then it is essential that politicians and courts be able to distinguish readily between conflict and nonconflict, between war and peace. If we cannot make such threshold distinctions, then we have little coherent or consistent basis for asserting that some acts of violence-or restrictions on rights-are appropriate and permissible, while others are inappropriate or illegal.

Guantanamo "Spy Ring" Case Takes Big Hit, USA TODAY, Sept. 8, 2004, at A1 (describing problems with military prosecutors' case against an alleged spy ring).

${ }^{93}$ See, e.g., Youngstown, 343 U.S. at 587-89 (finding that the presidential power to seize and possess mills could not be sustained because Congress had the exclusive constitutional authority to make all necessary laws); see also Humanitarian Law Project v. Ashcroft, 309 F. Supp. 2d 1185, 1198-1201 (C.D. Cal. 2004) (asserting that a statute that allows the Secretary of State to designate an organization as a foreign terrorist organization is vague).

${ }^{94}$ For documents pertaining to the Nuremberg judgments, see TRIAL OF THE MAJOR WAR CRIMINALS BEFORE THE INTERNATIONAL. MilitARY TRIBUNAL, NUREMBERG, 14 NOVEMBER 1945-1 OCTOBER 1946, at 1-42 (William S. Hein \& Co. 1995) (1948), available at http://www.yale.edu/lawweb/avalon/imt/imt.htm\#proc. For a discussion of war crimes prosecutions arising out of the civil war in the former Yugoslavia, see HUMAN RIGHTS WATCH, supra note 44. 
This is as true of domestic jurisprudence on national security issues as it is of the law of armed conflict. In times of peace, our constitutional doctrines mandate transparency in government and great respect for the rights of individuals. In times of national security crisis, U.S. courts may permit the government to undertake actions that would normally be considered unlawful and even unconstitutional, such as trials by military tribunals that do not afford standard due process protections, ${ }^{95}$ or indefinite detention of U.S. citizens with only minimal due process. ${ }^{96}$ To a great extent, the willingness of courts to permit such government actions in the name of national security (and the willingness of American citizens to tolerate such actions) is predicated on the notion that such actions are the exception, not the norm; that they are allowed only during emergencies, not forever. Here too, a great deal thus depends on the ability of politicians, citizens, and courts to make a reasonably principled determination of when we face a national security crisis and when we do not.

Drawing principled and analytically satisfying lines between war and peace, conflict and nonconflict, crisis and normalcy has always been difficult on the margins. It is clear enough, for instance, that World Wars I and II were international armed conflicts. Numerous

95 See Ex parte Quirin, 317 U.S. 1, 28, 48 (1942) (asserting that the President of the United States may try German-born U.S. residents in a military tribunal without a jury). For an overview of military tribunals in U.S. history, see REHNQUIST, supra note 5 (chronicling instances in U.S. history in which emergency situations have led to the suspension of rights); Roberto Iraola, Military Tribunals, Terrorists, and the Constitution, 33 N.M. L. REV. 95 (2003) (discussing military tribunals in the wake of the September 11 attacks); Carl Tobias, Detentions, Military Commissions, Terrorism, and Domestic Case Precedent, 76 S. CAL. L. REV. 1371 (2003) (examining the government's reliance on Quirin to litigate major terrorism cases). For a critique of the current use of military commissions, see Michal R. Belknap, A Putrid Pedigree: The Bush Administration's Military Tribunals in Historical Perspective, 38 CAL. W. L. REV. 433 (2002) (criticizing President Bush's order providing for the trial before military commissions of aliens suspected of terrorist activities); Evan J. Wallach, Afghanistan, Quirin, and Uchiyama: Does the Sauce Suit the Gander?, ARMY LAW., Nov. 2003, at 18 (asserting that post-September 11 military tribunals violate the Third Geneva Convention (Relative to the Treatment of Prisoners of War)); Jim Davis, Note, A Cautionary Tale: Examining the Use of Military Tribunals by the United States in the Aftermath of the September 11 Attacks in Light of Peru's History of Human Rights Abuses Resulting from Similar Measures, 31 GA. J. INT'L \& COMP. L. 423 (2003) (describing Peru's violations of internationally accepted standards of due process); Vladeck, supra note 76 (arguing that the executive branch does not possess the type of inherent constitutional detention power that it has exercised in holding "enemy combatants").

${ }^{96}$ See, e.g., Hamdi v. Rumsfeld, 296 F.3d 278, 283 (4th Cir. 2002), vacated and remanded by 124 S. Ct. 2633 (2004) (holding that "the district court appointed counsel and ordered access to the ['enemy combatant'] detainee without adequately considering the implications of its actions"). 
different nation-states formally declared war on numerous other nation-states; hostilities were widespread and ongoing; and millions upon millions of regular, uniformed soldiers were directly involved in the fighting. But more sporadic hostilities between nations, insurgencies within nations, and long-term occupations of territory have never been as amenable to simple categorizations: Do the intermittent skirmishes between India and Pakistan amount to an international armed conflict such that the international law of armed conflict is triggered? Is the Irish Republican Army subject to the law of armed conflict, or is it merely a criminal organization subject to domestic criminal law, as the British government has historically insisted? ${ }^{97}$

The law of armed conflict explicitly addresses some of these definitional questions, although it does not resolve them. Thus, the Geneva Conventions apply expressly to "all cases of declared war or of any other armed conflict" that may arise between states that are parties to the Conventions, "even if the state of war is not recognized by one of them." ${ }^{98}$ What constitutes an "international armed conflict" is not otherwise defined, but the insistence on the irrelevance of declarations of war makes it clear that "armed conflict" is to be conceptualized functionally, not formalistically. The Geneva Conventions of 1949 and the 1977 Additional Protocols distinguish, however, between armed conflicts that are international and those that are "internal," with only a small subset of the law of armed conflict applying in situations of purely internal armed conflict. ${ }^{99}$ Finally, Additional Protocol II also distinguishes between internal armed conflicts and mere "internal disturbances" or "tensions," which do not trigger the applicability of the law of armed conflict at all, except for the core prohibitions contained in Common Article $3^{100}$-and some commentators dispute even this. ${ }^{101}$

${ }^{97}$ See Mary Ellen O'Connell, Re-leashing the Dogs of War, 97 AM. J. INT'L L. 446, 454 (2003) (book review) ("The British government... has consistently maintained that the violence related to the crisis in Northern Ireland is criminal violence to which the Geneva Conventions do not apply ....”).

${ }_{98}$ Third Geneva Convention, supra note 10 , art. 2, 6 U.S.T. at 3318,75 U.N.T.S. at 86.

39 Only Common Article 3 of the Geneva Conventions and Additional Protocol II apply to noninternational armed conflicts. Id. art. 3, 6 U.S.T. at 3318-20, 75 U.N.T.S at 136-38; Protocol II, supra note 43, art. 1, 1125 U.N.T.S. at 4.

${ }^{100}$ See BOUCHET-SAULNIER, supra note 50, at 109 (characterizing Common Article 3 as applying to internal disturbances and tensions).

${ }^{101}$ See, e.g., John Yoo, Transferring Terrorists, 79 NOTRE DAME L. REV. 1183, 1197 (2004) (noting that the law of war, including Article 3 of the 1949 Geneva Conventions, does not apply to internal disturbances and tensions). 
The lines between these various levels and kinds of conflict-and the implications of drawing these lines-have been the subject of continuous scholarly and diplomatic debate, ${ }^{102}$ and Part III of this Article will discuss some of the issues and changes that have consistently rendered such line-drawing exercises problematic when it comes to the law of armed conflict. But these line-drawing exercises are even more problematic when we turn back to domestic jurisprudence on national security issues. The law of armed conflict offers some basic tests for determining the existence of armed conflict and thus the applicability of the law of armed conflict, although the utility of these tests has always been contested. In domestic national security jurisprudence, however, there are no such tests; courts have found no principled or universal basis on which to determine the existence of a "threat to national security."

As a result, each new case requires courts to struggle all over again with the boundaries between "purely domestic" matters and matters that implicate national security and foreign affairs, and this has increased the tendency of courts to rely on congressional and/or executive branch determinations. Even if we presume complete good faith on the part of the executive branch and Congress, however, these branches of government have been similarly unable to come up with a consistent and principled account of which matters implicate national security and which do not.

\section{ChanGES: GLOBAlization AND ASYMmetricAl THREAT}

The lines between conflict and nonconflict, war and peace, crisis and normalcy have always been contestable-and they have always been contested. The analytic categories on which the law of armed conflict depends have been unstable since they were first developed. This instability has been dramatically exacerbated by recent and accelerating changes in the nature of international politics and the nature of conflict and threat, however, so much so that many of the basic categories are no longer analytically justifiable at all. This section outlines briefly some of the background assumptions of the law of armed

${ }^{102}$ See, e.g., Bassiouni, supra note 23, at 201-02 (examining gaps and ambiguities in international law relevant to war crimes against humanity and genocide); Reisman \& Silk, supra note 23, at 459-60 (discussing the applicability of international law to the Afghan conflict of the 1980s); Stewart, supra note 23, at 314 (proposing unification of the law of armed conflict). 
conflict and the ways in which social, technological, and geopolitical change have rendered these assumptions ever more problematic.

Although every civilization in the world has traditions (often ancient traditions) governing conduct during hostilities, and although today most states throughout the world are parties to the Hague and Geneva Conventions, the modern law of armed conflict was essentially a creation of the West. It developed in reaction to the perceived excesses of the American Civil War, the wars of Italian unification, the Crimean War, the Franco-German wars, the Boer War, and, of course, World Wars I and II. ${ }^{103}$ The paradigmatic "conflict" envisioned by the drafters of the Hague and Geneva Conventions was a war between sovereign nation-states, in which well-organized regular armies fought each other on reasonably clearly defined battlefields. As a result, the Hague and Geneva Conventions devoted relatively little space to smaller-scale, episodic, and internal armed conflicts, and many of the rules laid out in these conventions thus seem today like quaint relics of a more chivalric time. ${ }^{104}$

Thus, for instance, one's status as a "lawful combatant" under the Geneva Conventions hinges, as a threshold matter, not on one's substantive actions but on certain questions of form: whether one is under responsible command, whether one wears "a fixed distinctive sign recognizable at a distance," and whether one carries arms openly. ${ }^{105}$ Similarly, the Hague and Geneva Conventions presuppose a clear distinction between front lines and battlefields, on the one hand, and civilian areas, on the other; and a correspondingly clear distinction between combatants and noncombatants. Once again, this hearkens back to an imagined past in which wars were fought by professional soldiers in elaborate uniforms, clashing on vast, open fields to the sound of bugles and drums.

War was never this tidy, of course; had it ever been so, the law of armed conflict would have been superfluous. Even at the moment of drafting, the Hague and Geneva Conventions were efforts to imagine more orderly and rational forms of bloodshed than had ever in fact

${ }^{10 y}$ See Howard, supra note 32, at 1, 10 (summarizing the circumstances leading to the creation of the Hague and Geneva Conventions).

${ }^{104}$ See generally Chris af Jochnick \& Roger Normand, The Legitimation of Violence: A Critical History of the Laws of War, 35 HARV. INT'L L.J. 49 (1994) (arguing that international law has historically served to legitimate war rather than to restrict wartime violence).

${ }^{105}$ Third Geneva Convention, supra note 10, art. 4, 6 U.S.T. at $3320-22,75$ U.N.T.S. at 138-40; INT'L \& OPERATIONAL LAW DEP'T, supra note 43, at 12. 
existed, and to impose on armed conflict rules that ranged from the moderately aspirational to the almost impossibly so. That said, the rules they developed served as useful benchmarks throughout much of the twentieth century. They perhaps did little, overall, to restrain the brutality and suffering caused by armed conflicts ${ }^{106}$ (indeed, some commentators have suggested that they may even have legitimized and increased the violence of war), ${ }^{107}$ but they nonetheless provided useful political and legal benchmarks that could be used to evaluate state and nonstate violence, ${ }^{108}$ and they also made it reasonably easy to distinguish between "war" and "nonwar."

As I have said, however, the categories and boundaries created and presupposed by the law of armed conflict were unstable from the beginning, ${ }^{109}$ and as the decades have passed, they have become still more unstable in the face of accelerating technological and social changes. Technologically, the development of ever more lethal weapons has been a perpetual challenge to law of armed conflict prohibitions on "unnecessary suffering" and to the principles of proportionality and discrimination. Atomic and hydrogen bombs, for instance, are by nature indiscriminate (and many would argue that they are also inherently disproportionate: the damage and suffering they cause is so immense that they could never be appropriately used)..$^{10}$ Other weapons, such as landmines, are designed to increase the safety

${ }^{106}$ See, e.g., Paul W. Kahn, Lessons for International Law from the Gulf War, 45 STAN. L. REV. 425, 436 (1993) ("[T]here is no direct correlation between complying with international legal rules and minimizing suffering.").

${ }^{107}$ See Jochnick \& Normand, supra note 104, at 50 ("[T] he laws of war have facilitated rather than restrained wartime violence.").

${ }^{108}$ Thus, for instance, mainstream human rights groups such as Human Rights Watch, while often critical of NATO actions during the 1999 air campaign against Serbia, had little difficulty in concluding that there was "no evidence of war crimes" committed by NATO. Human Rights WATch, CIVILIAN DEATHS IN THE NATO AIR CAMPAIGN 3 (2000). This assessment stands in stark contrast to Human Rights Watch's declaration that "Yugoslav President Slobodan Milosevic and his inner circle of political and military leaders are responsible for war crimes and crimes against humanity committed in Kosovo." HUMAN RIGHTS WATCH, In-Depth Report Documents Milosevic Crimes (Oct. 26, 2001), available at http://www.hrw.org/press/2001/10/ kosovo1026.htm.

${ }^{109}$ The use of aerial bombardment, the atom bomb, and widespread existence of resistance groups and partisans during World War II all challenged then-existing categories, and the Geneva Conventions did not wholly resolve these challenges.

${ }^{110}$ See, e.g., Legality of the Threat or Use of Nuclear Weapons, 1996 I.C.J. 226, 24344 (July 8) (noting the "unique characteristics of nuclear weapons," their "capacity to cause untold human suffering and their ability to cause damage to generations to come"). For an interesting discussion of this issue, see generally Paul W. Kahn, Nuclear Weapons and the Rule of Law, 31 N.Y.U. J. INT'L L. \& POL. 349 (1999). 
of those who deploy them; they allow for the destruction of the enemy when those who placed them are safely out of the way. For the same reason, of course, many mines are relatively indiscriminate; no human mind makes the ultimate decision about when they should be exploded, and they kill civilian children as readily as enemy combatants. ${ }^{111}$ Cluster bombs present similar problems: they are an effective means of killing large numbers of enemy combatants at once, but unexploded bomblets can remain a hazard to civilian populations for months or even years. ${ }^{112}$

As ever more sophisticated weapons have proliferated, many lethal weapons have become simpler, smaller, and cheaper-so simple, small, and cheap that even poorly organized insurgent movements can afford them, and younger and younger children can use them. Rocket-propelled grenades (RPGs) and various shoulder-fired missiles ${ }^{113}$ allow even one or two individuals to bring down airplanes and launch deadly attacks on distant areas. ${ }^{14}$ Meanwhile, light and cheap automatic weapons such as the AK-47 can be effectively used by children as young as eight or nine. ${ }^{115}$ The spread of scientific knowledge may also make it easier and cheaper for both state and nonstate actors to manufacture chemical, biological, and radiological weapons, and even Internet viruses, which have the potential to cause serious harm

"11 A global movement to ban antipersonnel mines led eventually to a widely signed treaty banning their use. See Convention on the Prohibition of the Use, Stockpiling, Production and Transfer of Anti-Personnel Mines and on their Destruction, Sept. 18, 1997, art. 1(1)(a), 2056 U.N.T.S. 241, 242 (banning the use of antipersonnel mines).

112 See Cluster Munitions: A Foreseeable Hazard in Iraq, Human Rights Watch (Mar. 2003), at http://www.hrw.org/backgrounder/arms/cluster031803.htm (calling for a moratorium on the use of cluster munitions).

${ }^{113}$ These missiles, known as "Man-Portable Air Defense Systems" (MANPADS), include models such as SA-7s, SA-14s, and S16s, the widely available Soviet equivalents of American "STINGER" missiles. See Arms Sale Monitoring Project: MANPADS Proliferation, Fed. of Am. Scientists, at http://www.fas.org/asmp/campaigns/manpads/ manpads.html (last visited Oct. 31, 2004) (explaining that the Russian-made SA-7, SA14 , and S16 are "among the most numerous and best known" MANPADS and "similar in capability" to the STINGER). There are currently an estimated 500,000 MANPADS in the world. Id.

114 See id. (explaining that MANPADS are "attractive to terrorists" because they are "lethal, ... highly portable and concealable,... inexpensive, ... relatively simple to operate, ... and [a] formidable threat to unprotected aircraft").

${ }^{115}$ Use of such weapons by child soldiers has been extensively documented. See, e.g., Human Rights Watch, The SCars of Death: Children abducted by the LORD'S RESISTANCE ARMY IN UNGANDA (1997) (recounting the experiences of child soldiers). 
by disrupting vital services. ${ }^{116}$ These changes have made it harder and harder for states to monopolize large-scale violence, and have been a boon to unscrupulous terrorist and insurgent groups. ${ }^{117}$

Other social and technological changes associated with the term "globalization" have also challenged state monopolization of mass violence. It is a truism to observe that advances in transportation and communication technologies have made the world a smaller place: groups once unable to coordinate effectively even in fairly small geographical areas can now coordinate across international borders cheaply and easily. Dozens of genies have been released from their bottles, and no one has yet found a mechanism for stopping them up again. With the end of the Cold War, ethnic and religious conflicts bubbled over from Central Europe to sub-Saharan Africa. In these conflicts, large segments of civilian populations at times have been mobilized (or intimidated) into the ranks of combatants; where the elimination of an entire ethnic or religious group is seen as the goal, traditional distinctions between combatants and noncombatants have had little salience. ${ }^{118}$ And at the same time that highly localized conceptions of identity have led to unspeakable brutality in some conflicts (between Serbs and Kosovar Albanians, for instance, or Hutus and

${ }^{116}$ Thus:

The appearance of ... new concepts of weapons has gradually blurred the face of war. Does a single "hacker" attack count as a hostile act or not? Can using financial instruments to destroy a country's economy be seen as a battle? ... Obviously, proceeding with the traditional definition of war in mind, there is no longer any way to answer the above questions. When we suddenly realize that all these non-war actions may be the new factors constituting future warfare, we have to come up with a new name for this new form of war: warfare which transcends all boundaries and limits, in short: unrestricted warfare.

QIAO \& WANG, supra note 17 , at 12.

${ }^{117}$ The military term for such new kinds of threats is "asymmetrical warfare." Charles J. Dunlap, Jr., A Virtuous Warrior in a Savage World, 8 U.S. A.F. ACAD. J. LEGAL STUD. 71, 71-72 (1997-1998). Since few states (or nonstate actors) can hope to directly challenge American military superiority, these actors turn increasingly to a variety of "strategies that seek to avoid [American] strengths....[I]n the modern context, asymmetrical warfare emphasizes... unconventional or nontraditional methodologies." Id. at 72. Much of the time, these methodologies may involve "what might be characterized as "neo-absolutist war' . . . . without rules or scruples," and focusing on "shattering the enemy's will by any means possible, including methods that defy recognized standards of acceptable behavior in war." Id. at 73.

${ }^{118}$ Consider the conflicts in Bosnia and Rwanda, for instance. See generally José E. Alvarez, Crimes of States/Crimes of Hate: Lessons from Rwanda, 24 YALE J. INT'L L. 365 (1999). 
Tutsis in Rwanda), increasingly globalized conceptions of identity are proving to be equally dangerous, as the rise of al Qaeda demonstrates.

The rise of global terrorism represents the newest and most serious challenge to the old law of armed conflict framework. ${ }^{119}$ The September 11 attacks, for example, were carried out by nineteen hijackers who hailed from several different countries, all of which are ostensibly U.S. allies. ${ }^{120}$ The hijackers had previously lived and trained in states as varied as Germany, Pakistan, Afghanistan, Chechnya and the U.S., where most of them lived openly for months or years. ${ }^{121}$ In addition to the September 11 attacks, al Qaeda is credited with the 1995 bombing of the World Trade Center, the 1998 attacks on the U.S. embassies in Kenya and Tanzania, the 2000 attack on the U.S.S. Cole in Yemen, and with attacks on other targets from Indonesia to Turkey. ${ }^{122}$ Since September 11, it has become clear that al Qaeda is an equal opportunity employer when it comes to nationality and ethnicity, if not when it comes to gender or ideology: al Qaeda operatives have allegedly included native-born American citizens, as well as British, French, Australian, and German citizens and nationals of various Arab and Muslim states. ${ }^{123} \mathrm{Al}$ Qaeda knows no borders, and its operatives wear no uniforms, operating by stealth more often than they operate openly. ${ }^{124}$

${ }^{119}$ The world community has consistently failed to come up with a definition of terrorism that all states accept as satisfactory. See Adam Roberts, Can We Define Terrorism?, OXFORD TODAY (2002), http://www.oxfordtoday.ox.ac.uk/archive/0102/14_2/ 04.shtml (last visited Sept. 20, 2004) (suggesting that terrorism is easy to condemn but difficult to define, and "sure to remain a box with a false bottom").

${ }^{120}$ See NAT'L COMM'N ON TERRORIST ATTACKS UPON THE U.S., THE 9/11 COMMISSION REPORT 1-4, 160-63, 231 (2004) (reporting that the hijackers boarding flights on September 11, 2001 included nationals of Egypt, Lebanon, Saudi Arabia, and the United Arab Emirates).

${ }^{121}$ See id. at 157, 160, 165, 224, 233, 235 (noting that three of the hijackers pursued higher education in Hamburg, Germany, plotted the attacks in Afghanistan, and then attended flight school in the United States and that others had been involved in the "jihad" in Chechnya and had received training in Afghanistan in 2000-2001).

${ }^{2}$ See Paul Butler, Principal Assistant Secretary of Defense, Briefing on Detainee Operations at Guantanamo Bay (Feb. 13, 2004) (detailing al Qaeda's extensive terrorist actions throughout the world), available at http://www.defenselink.mil/transcripts/ 2004/tr20040213-0443.html (last visited Sept. 14, 2004).

${ }^{129}$ Jose Padilla, the alleged "dirty bomb" plotter, is an American, Court: President Cannot Detain U.S. Citizen as Enemy Combatant, CNN.COM, Dec. 22, 2003, at http://www.cnn.com/2003/L.AW/12/18/padilla.case/; "shoe bomber" Richard Reid is British, Britons Shocked by Terror Links, CNN.CoM, Jan. 21, 2002, at http:// archives.cnn.com/2002/WORLD/europe/01/18/inv.britain.terror/index.html; and those held at Guantanamo represent some 32 different nations, Carol Rosenberg, Camp Detainees Represent 32 Nations, MIAMI HERALD, Feb. 21, 2002, available at http://www.miami.com/mld/miamiherald/news/2713066.htm?1c\&lc.

${ }^{124}$ See Secretary of State Donald M. Rumsfeld, Department of Defense News Brief- 
And these tactics work: al Qaeda has proven capable of massive violence and has caused thousands of deaths. ${ }^{125}$

\section{THE BREAKDOWN OF BOUNDARIES}

These recent and continuously accelerating changes have further destabilized the boundaries taken for granted by the laws of armed conflict, and they have also further problematized the distinction in domestic jurisprudence between national security matters and purely domestic matters. This section briefly examines some of the categories that have become most untenable as a result of the geopolitical changes of the last few decades, and in particular as a result of post$9 / 11$ events.

\section{A. "International" Versus "Internal" Armed Conflicts}

As noted above, the Geneva Conventions of 1949 and their 1977 Additional Protocols distinguish between international armed conflicts and armed conflicts "not of an international character." Geneva Conventions of 1949 are fully applicable only to situations of international armed conflict (as were the Hague Conventions before

ing (Feb. 8, 2002) (describing al Qaeda as a "non-state, terrorist network" whose forces made up part of the loosely organized Taliban and noting Taliban efforts "to blend in with civilian non-combatants, hiding in mosques and populated areas," wearing no "distinctive signs, insignias, symbols, or uniforms"), available at http:// www.defenselink.mil/transcripts/2002/t02082002-0208sd.html (last visited Sept. 14, 2004). This failure to distinguish themselves from civilians has noteworthy implications: it is one of the primary factors the Bush administration cited in support of its decision to regard the Taliban and al Qaeda fighters as "unprivileged combatants" who could be denied protective POW status under the Third Geneva Convention. See Goldman \& Tittemore, supra note 6, at 25-26 (describing legal arguments the Bush administration advanced for denying Taliban and al Qaeda fighters POW status); see also Jim Garamone, Rumsfeld Explains Detainee Status, AM. FORCES PRESS SERVICE, Feb. 8, 2002 (discussing Secretary Rumsfeld's statement on the applicability of the Geneva Conventions to the Taliban and al Qaeda), available at http://www.defenselink.mil/ news/feb2002/n02082002_200202086.html.

${ }^{125} \mathrm{Al}$ Qaeda is, of course, only the most widely known international terrorist organization. While few other terrorist organizations appear to have a similarly global reach, local and regional terrorist organizations have long had a similar capacity to cause harm. Most recently, for instance, Chechen terrorists took over a school in Beslan, in Russia's North Ossetian region. In the resulting siege, close to 400 civiliansmainly women and small children-died. Russia School Siege Tops 350, CNN.COM, Sept. 5, 2004, at http://www.cnn.com/2004/WORLD/europe/09/04/russia.school/ index.html.

${ }^{126}$ See discussion supra Part II.C (describing the Geneva Conventions' attempt to define which conflicts should be subject to international law). 
them). ${ }^{127}$ When conflicts are purely "internal," only Article 3, which is common to all four Geneva Conventions, applies. ${ }^{128}$ The distinction between international and internal armed conflicts traditionally has great significance, since if a conflict is declared to be internal, it does not trigger the law of armed conflict except for the minimal provisions of Common Article 3:

I. Persons taking no active part in the hostilities, including members of armed forces who have laid down their arms and those placed hors de combat by sickness, wounds, detention, or any other cause, shall in all circumstances be treated humanely, without any adverse distinction founded on race, colour, religion or faith, sex, birth or wealth, or any other similar criteria ....

[T] he following acts are and shall remain prohibited at any time and in any place whatsoever with respect to the above-mentioned persons:

(a) violence to life and person, in particular murder of all kinds, mutilation, cruel treatment and torture;

(b) taking of hostages;

(c) outrages upon personal dignity, in particular, humiliating and degrading treatment;

(d) the passing of sentences and the carrying out of executions without previous judgment pronounced by a regularly constituted court affording all the judicial guarantees which are recognized as indispensable by civilized peoples.

II. The wounded and sick shall be collected and cared for. ${ }^{129}$

Additional Protocol II of 1977, which has been ratified by 156 states, ${ }^{130}$ extends to noninternational armed conflicts some of the same rules applicable to international armed conflicts, largely by expanding upon the meaning of Common Article $3 .^{131}$ Nonetheless, the

${ }^{127}$ See Hague Convention, supra note 38, art. 2, 36 Stat. at 2290 (restricting the Convention provisions to conflicts between the contracting nations).

1281949 Geneva Conventions, supra note 10, art. 3, 6 U.S.T. at 3116-18, 3220-22, $3318-20,3518-20,75$ U.N.T.S. at $32,86,136,288$

${ }^{129}$ Id. art. 3, 6 U.S.T. at $3116-17,3220-22,3318-20,3518-20,75$ U.N.T.S. at 32,86 , $136,288$.

${ }^{130}$ See ICRC, supra note 47 (listing all states party to the Geneva Conventions and their Protocols).

${ }^{191}$ Protocol II, supra note 43, art. 1, 1125 U.N.T.S. at 611 ("This Protocol ... develops and supplements Article 3 common to the Geneva Conventions ... [and] shall 
rules applicable in international armed conflicts and in internal armed conflicts are far from parallel; as one commentator has noted, the Geneva Conventions and their Additional Protocols contain close to 600 articles, but only Common Article 3 and the 28 articles of Additional Protocol II apply to noninternational armed conflicts. ${ }^{132}$ What's more, several dozen nations, including the U.S., have not ratified Additional Protocol II (although the U.S. has agreed to be bound to most of it as a matter of customary international law or U.S. policy). ${ }^{133}$ As a result, the distinction between international and internal armed conflict still has great significance.

Additional Protocol II only applies, in any case, to those noninternational

armed conflicts ... which take place in the territory of a High Contracting Party between its armed forces and dissident armed forces or other organized armed groups which, under responsible command, exercise such control over a part of its territory as to enable them to carry out sustained and concerted military operations and to implement this Protocol. $^{134}$

This means that the Protocol does not technically apply to clashes between two insurgent groups, that it probably does not apply to clashes between insurgents and police or state-sponsored paramilitary groups (rather than regular military forces), and that it does not apply when insurgent forces have an overly decentralized command structure or lack a territorial base. The Protocol also does not apply to "situations of internal disturbances and tensions, such as riots, isolated and sporadic acts of violence and other acts of a similar nature."

Since the end of World War II, there have been very few "international armed conflicts" as defined by the Geneva Conventions. ${ }^{136}$ To a significant extent, the U.N. Charter structure, in conjunction with Cold War politics, kept states from direct conflict with one another. Although recent years have seen several classic examples of international armed conflicts (including the NATO intervention in Kosovo,

apply to all armed conflicts which are not covered by Article 1 of the Protocol Additional....").

${ }^{132}$ Stewart, supra note 23 , at 319-20.

${ }^{133}$ See INT'L \& OPERATIONAL LAW DEP'T, supra note 43, at 7-13 (describing those aspects of the Additional Protocols considered binding by the United States).

${ }_{134}$ Protocol II, supra note 43, art. 1, 1125 U.N.T.S. at 611.

${ }^{135} \mathrm{Id}$

${ }^{136}$ See 1949 Geneva Conventions, supra note 10, art. 2, 6 U.S.T. at 3115,3218 , $3317,3517,75$ U.N.T.S. at $32,86,136,288$ (declaring that the Conventions apply to "all cases of declared war or of any other armed conflict" between signatory states). 
the U.S. invasion of Afghanistan, and, most recently, the U.S. invasion of Iraq), ${ }^{137}$ the overwhelming majority of recent conflicts have not fit squarely either into the category of "international" armed conflict or "internal" armed conflict. Most notably, recent decades have witnessed two common kinds of armed conflicts that defy easy categorization: conflicts in which insurgent groups train and attack from across international borders because neighboring states are too weak to prevent their territory from being used as a base, and conflicts in which one or more "outside" states provide material support (weapons, financing, training, safe harbor, etc.) to insurgents fighting within another state, despite official denials of any involvement. ${ }^{138}$ Messy crossborder insurgencies and proxy wars seem more than just "internal," but they frequently do not trigger the full applicability of the law of armed conflict. ${ }^{139}$

The rise of globally diffuse terrorist networks poses even more of a conundrum. Al Qaeda is clearly not a state, much less a "High Contracting Party" to the Geneva Conventions, ${ }^{140}$ so a "conflict" between the U.S. and al Qaeda apparently cannot be an "international armed conflict" as defined by the Geneva Conventions. ${ }^{141}$ On the other hand, it makes no sense to conceptualize a conflict with al Qaeda as an "internal" armed conflict either: al Qaeda has some presence in the U.S., to be sure, but its permanent U.S. presence appears to be minimal, and it also has some presence in dozens of other states around the globe. It attacks U.S. interests around the globe, and the U.S. accordingly wishes to attack its interests around the globe. But if the struggle between the U.S. and al Qaeda is conceptualized as an armed conflict, what aspects of the law of armed conflict are applicable beyond, perhaps, the minimal rules laid out in Common Article 3 of the Geneva Conventions?

${ }^{137}$ Before that, international armed conflicts included those in Vietnam, Korea, and Afghanistan.

133 Consider, for example, the long-running Lord's Resistance Army insurgency in Uganda and intermittent Ugandan government support for the insurgent Sudan People's Liberation Army, or the disastrous conflict in the Congo, which ultimately drew in nearly a dozen African states, some covertly, some overtly.

${ }^{139}$ But see Military and Paramilitary Activities (Nicar. v. U.S.), 1986 I.C.J. 14 (June 27) (noting that involvement in an internal armed conflict by another state triggers the rules governing international armed conflicts).

${ }^{140}$ Until recently al Qaeda clearly operated in Afghanistan with the blessing of the Taliban, Afghanistan's de facto government, but the Taliban can no longer make any claim to statehood itself.

${ }^{141}$ See supra note 136 (concerning Common Article 2). 


\section{B. Crime Versus Conflict}

This raises a related question: on what basis can we differentiate between those acts of violence that are best conceptualized as "crimes" (subject to criminal law), and those acts of violence best conceptualized as "armed conflicts" (subject to the law of armed conflict)? 142 $^{\mathrm{Al}-}$ though the Geneva Conventions and its Additional Protocols do not provide an obvious answer to this question, they take it for granted that not every act of violence should be construed as part of an armed conflict. Article 1.2 of Additional Protocol II states that the Protocol "shall not apply to situations of internal disturbances, and tensions such as riots, isolated and sporadic acts of violence and other acts of a similar nature, as not being armed conflicts." ${ }^{149}$ If these are clearly not armed conflicts, the implication is that the law of armed conflict is not triggered, and that states should deal with these threats through their own domestic criminal law, ${ }^{144}$ supplemented if necessary by bilateral and multilateral international cooperation agreements. Since "isolated and sporadic acts of violence" are not armed conflicts, there can be no combatant immunity for the perpetrators, who are therefore subject to subsequent trial and punishment for their conduct. ${ }^{145}$

Protocol II does not expressly exclude from consideration clashes inside a state. Article 1.1 states that the Protocol applies to armed conflicts between two or more insurgent groups, or clashes between state military forces and insurgent groups that are not "organized" and "under responsible command," or that do not "exercise such control over a part of [the state's] territory as to enable them to carry out sustained and concerted military operations and to implement this Protocol." B46 negative implication, however, such clashes too seem to be left to domestic criminal law rather than to the international law of armed conflict. (This, indeed, is what the U.S. government did in the case of the 1995 bombing of the Federal Building in Oklahoma

${ }^{142}$ See Ronald J. Sievert, War on Terrorism or Global Law Enforcement Operation?, 78 NOTRE DAME L. REV. 307, 308-09 (2003) (characterizing the dichotomy of the war on terrorism as both a law enforcement and a military problem).

${ }^{143}$ Protocol II, supra note 43, art. 1.2, 1125 U.N.T.S. at 611.

${ }^{144}$ See O'Connell, supra note 97, 454 ("The British government, for example, has consistently maintained that the violence related to the crisis in Northern Ireland is criminal violence to which the Geneva Conventions do not apply ....").

${ }^{145}$ See Emanuel Gross, Trying Terrorists-Justification for Differing Trial Rules: The Balance Between Security Considerations and Human Rights, 13 IND. INT'L \& COMP. L. REV. 1,97 (2002) (arguing that it is a democratic state's responsibility to guarantee public safety by giving terrorists a fair trial and thereby only convicting the guilty).

${ }^{46}$ Protocol II, supra note 43, art. 1.1, 1125 U.N.T.S. at 611. 
City, which killed 168 people. The main perpetrators, Timothy McVeigh and Terry Nichols, were charged with ordinary domestic crimes and tried by ordinary civilian courts; no U.S. government officials seriously considered applying the law of armed conflict to the bombing, instead of domestic criminal law.) ${ }^{147}$

How, then, should the U.S. struggle against al Qaeda be conceptualized? As noted in the previous sections, it does not appear to be a classic "international armed conflict" as defined by the Geneva Conventions, but it can hardly be said to be a classic "internal armed conflict" either. Al Qaeda holds no U.S. territory and operates around the globe. Is the struggle between the U.S. and al Qaeda in fact an armed conflict at all?

In the wake of September 11, many commentators, especially in the human rights law community, insisted that the phrase "the war on terrorism" should be construed only metaphorically, arguing that the September 11 attacks were not part of an "armed conflict" but were simply a crime, albeit a crime of colossal magnitude. Since the conflict with al Qaeda could neither be conceptualized as "international" nor "internal," these commentators argued, it had to be the case that it was not an armed conflict at all. ${ }^{148}$ Although al Qaeda is interna-

${ }^{147}$ Notably, McVeigh himself-a U.S. Army veteran decorated for combat bravery in the Gulf War-sought to claim, in effect, that he was a combatant, describing deaths of children as "collateral damage." FBI: McVeigh Knew Children Would Be Killed in OKC Blast, CNN.COM, Mar. 29, 2001, at http://www.cnn.com/2001/U.S./03/29/ mcveigh.book.01/index.html.

${ }^{148} \rightarrow$ ? Joan Fitzpatrick, Agora: Military Commissions: Jurisdiction of Military Commissions and the Ambiguous War on Terrorism, 96 AM. J. INT'L L. 345, 347 (2002) (arguing that the phrase "war on terrorism" is ambiguous and "exceeds accepted definitions of international armed conflict"); Joan Fitzpatrick, Sovereignty, Territoriality and the Rule of Law, 25 HASTINGS INT'L \& COMP. L. REV. 303 (2002) (arguing that the Bush administration has pursued "a highly problematic armed conflict alternative to the criminal law paradigm, which is readily available to combat terrorist acts and threats"); see also Michael Howard, What's in a Name?: How to Fight Terrorism, ForE1GN AFF., Jan./Feb. 2002 , at 8 (arguing that the use of the phrase "war on terrorism" is both "dangerous" and "counterproductive" because "it arouses an immediate expectation, and demand, for specific military action against some easily identifiable adversary"); Alain Pellet, $\mathrm{No}$, This Is Not War! (Oct. 3, 2001), at http://www.ejil.org/forum_WTC/ny-pellet.html (asserting that the September 11 attacks were not war crimes and "should lead to the rapid adoption of new instruments designed to address the new threats looming over the world"). For a more nuanced version of this argument, see Mark A. Drumbl, Victimhood in Our Neighborhood: Terrorist Crime, Taliban Guill, and the Aysmmetries of the International Legal Order, 81 N.C. L. REV. 1, 5 (2002), which argues that "there are [important] consequentialist, communitarian, and deontological reasons why the $[9 / 11]$ attacks [and terrorism in general] should be constructed as criminal attacks." But see Derek Jinks, September 11 and the Laws of War, 28 YALE J. INT'L L. I, 12-13 (2003) (arguing that the events of $9 / 11$ were an armed conflict governed by the rule applicable to 
tionalized, it is not a state. In any case, al Qaeda's attacks were relatively isolated and sporadic; al Qaeda holds no defined territory and controls no population. Thus, the argument was that al Qaeda was best analogized to global organized crime networks, such as networks of weapons or drug traffickers. Addressing such global criminal networks requires creativity and international cooperation; it requires the use of domestic criminal law and other domestic and international legal tools as well, such as multilateral agreements to freeze assets of international criminal enterprises-but it does not require (and is not subject to) the international law of armed conflict.

The response from the Bush administration was that although such an approach might suffice to combat organized crime, global terrorism is a different sort of animal and the "war on terror" is no mere metaphor. ${ }^{149}$ Global drug trafficking networks and other international criminal enterprises occasionally carry out murders, and they do great social harm, but the violence and harm caused by al Qaeda are of a different order. The September 11 attacks were intended to cause mass death, and they did cause mass death. Al Qaeda leaders have stated that they regard themselves as "at war" with the United States, ${ }^{150}$ and that they intend to continue to plan attacks against U.S.

noninternational armed conflicts). Jinks argues, however, that not all terrorism should be considered part of an armed conflict. Id.

${ }^{149}$ See, e.g., Spencer Hsu \& Dana Milbank, Kerry Rips Cheney Statement, WASH. Post, Sept. 9, 2004, at A06 (quoting Vice President Dick Cheney as criticizing Kerry for his allegedly "pre-9/11 mind-set," characterized by considering that "these terrorist attacks are just criminal acts and that we're not really at war"); see also Michael Chertoff, Law, Loyalty, and Terror: Our Legal Response to the Post-9/11 World, WKLY. STANDARD, Dec. 1, 2003 , at 15 (observing that, with a goal of destroying the United States and a willingness to employ weapons of mass destruction to achieve that end, al Qaeda represented "as serious a threat to the national security of the United States as one could envision"); Butler, supra note 122 (quoting the November 2001 remarks of President George W. Bush, including that "[i]nternational terrorists have carried out attacks on the United States on a scale that has created a state of armed conflict that requires the use of United States armed forces"); News Release, U.S. Department of Defense, DOD Responds to ABA Enemy Combatant Report (Oct. 2, 2002) (quoting U.S. Department of Defense General Counsel William Haynes as stating, "the United States is currently in a state of war with al Qaeda, one that triggers executive branch authority to prevent further attacks"), available at http://www.defenselink.mil/releases/2002/b10022002_ bt497-02.html; Joe Whitley, General Counsel for the Department of Homeland Security, Comments at the University of Virginia School of Law (Feb. 28, 2004) ("We are at war. The president has said we're at war, and the House and the Senate have said we're at war, and anyone who doesn't think this is a real war is completely out of touch.") (notes of comments on file with author).

${ }^{150}$ See, e.g., Butler, supra note 122 . Butler states:

[I]n 1996, Osama bin Laden issued a public fatwa declaring war on the United States. In February 1998 he issued another public fatwa . . . in which 
interests, including attacks aimed at civilian populations. To the Bush administration, although al Qaeda's attacks on America are not entirely continuous, they are also not "isolated" or "sporadic"; on the contrary, the September 11 attacks were part of a series of attacks that began with the 1993 bombing of the World Trade Center and continue to this day, although no attacks have been as spectacular or deadly as the September 11 attacks.

Additionally, according to the Bush administration, conceptualizing al Qaeda's attacks as mere "crimes" risks eviscerating U.S. efforts to prevent more attacks. If the U.S. is constrained by "ordinary" law, it cannot launch preemptive strikes against al Qaeda either at home or in other nations, but must instead wait on the slow processes of international legal cooperation abroad, and the warrants and showings of probable cause at home. Such techniques may be adequate for even the most sinister Colombian drug gangs, but they are unlikely to have much effect on an organization as deadly as al Qaeda.

How should we decide whether al Qaeda is a criminal enterprise or a belligerent armed force? The law of armed conflict provides no clear guidance, and it seems to me that the Bush administration's arguments for viewing the September 11 attacks as "armed conflict" are-from a legal perspective-at least as persuasive as the arguments for viewing the September 11 attacks as crimes. The law of armed conflict's line between crime and armed conflict was drawn in a different era, before the internet, before cell phones, before the advent of mass air travel, before the end of the Cold War scattered deadly weapons around the globe, and before the collapse of so many weak governments that were once propped up by the U.S. and the Soviet Union. There is no longer any basis for asserting a clearly discernable line between crime and conflict. ${ }^{151} \mathrm{Al}$ Qaeda will not be unique; in the future, there will be more and more al Qaedas, organizations that have something in common with criminal gangs and something in common with armies.

he said that it was the absolute obligation of his followers to kill Americans, civilian or military, wherever they could be found....

So the law of armed conflict governs what we're doing here.

The text of the 1998 Fatwa is available at http://www.pbs.org/newshour/terrorism/ international/fatwa_1998.html (last visited Dec. 1, 2004).

${ }_{151}$ See, e.g., QIAO \& WANG, supra note 17, at 222 (asserting that unrestricted "warfare in the age of globalization" has essentially filled the "chasm between warfare and non-warfare"). 
This is not to say that the Bush administration's decision to conceptualize the struggle against al Qaeda in terms of armed conflict was either inevitable or wise. It was a policy decision, and a policy decision that was neither mandated nor precluded by existing legal norms. Like any policy decision, it can be subjected to a cost-benefit analysis: are the potential gains of conceptualizing the "war on terror" as a literal war worth the potential costs? ${ }^{152}$ But it is important to draw a distinction between the legal arguments and the policy arguments.

Although the policy decision to view the "war on terror" as a literal war is legally plausible, the potential implications of this policy decision are staggering. If the law of armed conflict governs U.S. efforts to combat al Qaeda, then the government can plausibly assert that it should have the power to detain U.S. citizens on U.S. territory and hold them indefinitely and without charge, either as prisoners of war or as unlawful combatants. In neither case would they be entitled to trial in a regular court. This is the argument made by Bush administration lawyers in the case of terror suspect Jose Padilla, who was detained in Chicago after getting off a plane from Pakistan. While the Supreme Court's recent decision in Hamdi suggests that the Court considers such government assertions overreaching, the Court pointedly refused to decide the Padilla case on the merits, and Padilla remains in custody today, still uncharged and without having had any opportunity to challenge the basis for his detention. ${ }^{153}$

For that matter, if the law of armed conflict is applicable even to actions taken by the United States on U.S. territory, there seems to be

${ }^{152}$ Of course, this is not necessarily an either/or choice: one could conceptualize the U.S. military actions in Afghanistan as an international armed conflict but still conceptualize support for terrorism by persons in the U.S. as crime. See Jinks, supra note 148, at 42-44 (arguing that, pursuant to Common Article 3 of the Geneva Conventions, individual criminal liability may be imposed on people who violate the substantive prohibitions of Article 3).

${ }^{153}$ Hamdi v. Rumsfeld, 124 S. Ct. 2633 (2004); Rumsfeld v. Padilla, 124 S. Ct. 2711 (2004). Jose Padilla was arrested in Chicago in May 2002. Padilla, 124 S. Ct. at 2715. Padilla was initially held as a federal material witness whose testimony might be relevant to other terrorism-related cases. Id. Federal officials told the press that Padilla was in contact with al Qaeda and had planned to create a so-called "dirty bomb." Padilla v. Rumsfeld, 352 F.3d 695, 701 (2d Cir. 2003), vacated and remanded by 124 S. Ct. at 2711. A month after his initial detention, the President designated Padilla an "enemy combatant" (and presumptively an unlawful combatant). 124 S. Ct. at 2715. Padilla was transferred to military custody, where he has remained ever since. Id. at 2716. The government originally did not charge Padilla with any crime, did not permit him access to counsel, and did not say whether or not he would eventually face charges before a military tribunal. $352 \mathrm{~F} .3 \mathrm{~d}$ at 700 . This case was eventually disposed of by the Supreme Court on jurisdictional grounds. 124 S. Ct. at 2727. 
no legal bar to preemptive government killings of suspected al Qaeda operatives in the U.S. (including U.S. citizens) although such killings would, in peacetime, constitute extrajudicial executions. ${ }^{154}$ If such governmental detentions and killings are permissible, this virtually eliminates the rule of law as we have come to know it.

\section{Geographical Boundaries}

Allow the President to invade a neighboring nation, whenever he shall deem it necessary to repel an invasion... and you allow him to make war at pleasure. . . . If to-day, he should choose to say he thinks it necessary to invade Canada, to prevent the British from invading us, how could you stop him? You may say to him, 'I see no probability of the British invading us' but he will say to you 'be silent; I see it, if you don't.'

- Abraham Lincoln ${ }^{155}$

The "crime or conflict" question is closely related to another traditional distinction drawn by the law of armed conflict. The traditional paradigm of armed conflict assumes that at any given time, it will be readily apparent where the armed conflict is taking place and where it is not. To put it another way, the traditional paradigm assumes clear spatial boundaries between zones of war and zones of peace.

During World War II, for example, some states were at war, and others were neutral; thus, there was armed conflict in France, Germany, and Britain, but not in Switzerland. Switzerland was at peace, and for any of the warring parties to use military force within Switzerland would have been a clear breach of international legal norms. If the U.S. wanted to kill a German military official who lived in Switzerland, there was no legal basis for doing so, since Switzerland was not at war with anyone. If a German official in Switzerland committed a crime against an American, the only legal recourse of the U.S. government would be to urge the Swiss authorities to arrest the German criminal, and perhaps extradite him to face trial in the U.S. Since Switzerland was not a party to the armed conflict occurring in much

${ }^{154}$ See infra text accompanying notes 158-60 (discussing the U.S. justification for the 2002 missile strike on a car allegedly carrying al Qaeda operatives in Yemen, which killed six people including a U.S. citizen).

${ }_{155}$ Quoted in Arthur Schlesinger, Jr., The Imperial Presidency Redux, WASH. POST, June 28, 2003, at A25. 
of the rest of Europe, the U.S. could not legally abduct or kill a German national (or anyone else) inside Switzerland, regardless of any compelling political or military reasons for doing so. ${ }^{156}$

The distinction between zones of war and zones of peace-between spatial areas in which the law of armed conflict governs and spatial areas in which "ordinary" domestic law and international agreements govern-is another once clear-cut distinction that no longer seems tenable in light of recent events. ${ }^{157}$ This was driven home by the 2002 U.S. missile attack on a car thought to be carrying al Qaeda operatives in Yemen that killed six people, including a U.S. citizen. The car had apparently been monitored for some time by both Yemeni and American intelligence agencies, since it was thought to be used by al Qaeda officials. As the car drove through Yemen's Marib region, it was struck by a Hellfire missile fired from an unmanned CIA airplane, a "predator drone."158

The U.S. justification for the attack was again straightforward: ${ }^{159}$ al Qaeda operates in numerous countries, and to effectively defend U.S. interests against future-and perhaps imminent-attacks, the U.S. may need at times to make preemptive strikes in self-defense. ${ }^{160} \mathrm{Al}$

${ }^{156}$ History is replete with examples of successful state abductions and killings in other sovereign states, but it is clear that such acts violate international law, though their domestic legal consequences are minimal. Consider, for example, the abduction of Eichmann from Argentina by Israeli forces. Attorney-Gen. of Israel v. Eichmann, 36 I.L.R. 277 (Isr. 1962); see also United States v. Alvarez-Machain, 504 U.S. 655, 657 (1992) (holding that the defendant Mexican citizen's forcible abduction did not prohibit his trial in the United States for crimes committed in Mexico). But see Sosa v. Alvarez-Machain, 124 S. Ct. 2739 (2004) (upholding the right of the defendant in United States v. Alvarez-Machain to sue in tort under 28 U.S.C. $\$ 1350(2000)$, based on a limited interpretation of the law of nations).

${ }^{157}$ See QIAO \& WANG, supra note 17, at 8 ("[T] he battlefield will be everywhere.").

${ }^{158}$ CIA 'Killed al-Qaeda Suspects' in Yemen, BBC News, Nov. 5, 2002, available at http://news.bbc.co.uk/2/hi/middle_east/2402479.stm.

${ }^{159}$ Straightforward, but piecemeal. The Bush administration offered only a piecemeal account of the Yemen strike. See, e.g., News Briefing, U.S. Department of Defense, (Nov. 4, 2002) (transcript available at http://www.defenselink.mil/ transcripts/2002/t11042002_t1104sd.html) (quoting Rumsfeld as refusing to elaborate on any element of the Yemen attack). National Security Advisor Condoleezza Rice later defended the attack, saying, "We're in a new kind of war, and we've made very clear that it is important that this new kind of war be fought on different battlefields ... [The killing was] well within the bounds of accepted practice . . I can assure you that no constitutional questions are raised here." Witt, supra note 8 , at 1 .

${ }^{160}$ Mofidi \& Eckert, supra note 7, at 75-76, echo the logic used by the United States. They argue:

The UN Charter, in Articles 2(4) and 51, appears to contemplate such use of force.... Although Article 2(4) prohibits a member state from using force against another state, Article 51 creates an exception to that prohibition by 
Qaeda was present in Yemen, and had previously struck a U.S. target in Yemen (the October 2000 attack on the U.S.S. Cole in Yemeni waters, which killed 17 American sailors). The U.S. had evidence that al Qaeda operatives in Yemen were planning another attack on U.S. interests. Article 51 of the U.N. Charter declares that states have an "inherent right of individual or collective self-defence if an armed attack occurs against [them], until the Security Council has taken measures necessary to maintain international peace and security." ${ }^{161}$ The missile attack on the al Qaeda suspects in Yemen was just such a permissible act of self-defense, allowed under both the U.N. Charter and the law of armed conflict. Alternatively, argued the U.S., the doctrine of preemptive self-defense is unnecessary, because the mere presence of the enemy - al Qaeda-in Yemen automatically rendered Yemen part of the conflict zone, in which the U.S. could legitimately take military action against enemy combatants. ${ }^{162}$

Here too, many in the human rights law and international law communities protested. ${ }^{168}$ Amnesty International, for example, ig-

permitting the use of force in self-defense "if an armed attack occurs." Although it seems plausible that the Charter's drafters, in formulating that phrase, envisioned an attack on a state by another state, the language is not on its face limited to that situation. It would not be unreasonable, therefore, to apply the language broadly to encompass the $9 / 11$ attacks-commandeering passenger jetliners to serve as weapons against important U.S. commercial and military centers.

Id. (internal citation omitted); see also DINSTEIN, supra note 31, at 240 (arguing that "[j] ust as [State A] is entitled to exercise self-defense against an armed attack by [State $B$ ], it is equally empowered to defend itself against armed bans operating from within [State B]").

${ }^{161}$ U.N. CHARTER, art. 51.

162 See Dana Priest, CIA Killed U.S. Citizen in Yemen Missile Strike; Action's Legality, Effectiveness Questioned, WASH. POST, Nov. 8, 2002, at A1. Priest reports:

The administration, working with the authority of a presidential finding that permits covert actions against Osama bin Laden's al Qaeda terrorist network, considered al-Harithi and his traveling party a military target-'combatants' under international law. Officials further contend that Sunday's missile strike was an act of self-defense, which is also permitted under the international laws of war, because al-Harithi already had allegedly attacked the United States in October 2000 when he helped blow up the USS Cole, killing 17 sailors. Administration officials, intelligence operatives and military analysts, frustrated with the slow, torturous pace of locating and capturing individual terrorists in lawless areas of countries such as Yemen, praised the CIA strikes as an innovative way to get the job done.

Id.

${ }^{163}$ See Witt, supra note 8, at 1 (noting the responses of Amnesty International and Sweden's foreign minister); see also U.S. Official Defends CIA Strike; Agencies Reportedly Given Broad Authority to Attack by Bush, SEATTLE TIMES, Nov. 11, 2002, at A9. 
nored the argument relating to preemptive self-defense (which has been widely criticized on the grounds that the use of force in selfdefense should only be permitted to ward off an "imminent" threat), ${ }^{164}$ and argued simply that the laws of armed conflict were not applicable to the Yemeni missile strike:

Under existing international humanitarian law, it is not possible to have an international armed conflict between a state on the one hand and a nonstate actor on the other, should the armed group not form part of the armed forces of a Party to the Geneva Conventions. ... There is no armed conflict between the U.S. and Yemen, and the Yemeni Government clearly cooperated in the air strike. In addition, there is no internal armed conflict between the government of Yemen (with the support of U.S. forces) and al-Qa'ida. Accordingly, the proper standards applicable to this situation were law enforcement standards . . . ${ }^{165}$

If law enforcement standards, rather the law of armed conflict, controlled, then the missile strike takes on a different and more sinister character. As Amnesty International put it, "if the attack was a deliberate killing, in lieu of arrest, in circumstances in which the men did not pose an immediate threat, the killings would amount to extrajudicial executions in violation of international human rights law." Presumably, such extrajudicial killings would also violate Yemeni law, and they would certainly violate U.S. law, particularly with regard to the U.S. citizen who was killed in the attack. As suggested in the previous section, it goes without saying that in normal times, the U.S.

${ }^{164}$ See, e.g., Lawyers' Comm. for Nuclear Pol'y Inc., The United Nations Charter and the Use of Force Against Iraq, at http://www.Icnp.org/global/Iraqstatemt.3.pdf (citing Daniel Webster's statement that self-defense is justified only when the threat is "instant, overwhelming, and leaving no choice of means, and no moment for deliberation"); see also DINSTEIN, supra note 31, at 177-245 (discussing the use of self-defense after an "armed attack"); OPPENHEIM's INTERNATIONAL LAW 422 (Sir Robert Jennings \& Sir Arthur Watts eds., 9th ed. 1992) (arguing that the use of force in self-defense is justified under international law when "an armed attack is launched, or is immediately threatened, against a state's territory or forces (and probably its nationals); there is an urgent necessity for defensive action against that attack; there is no practicable alternative to action in self-defence ..." (emphasis added)); Drumbl, supra note 148, at 27-28 (discussing the requirement of an "armed attack").

${ }^{165}$ AMNESTY INT'L, supra note 14, at 23. This sentiment was echoed by others such as Swedish foreign minister, Anna Lindh, who called the Yemen attack "a summary execution." Witt, supra note 8 , at 1.

${ }^{166}$ AMNESTY INT'L, supra note 14, at 21; see also O'Connell, supra note 97, at 454-55 (calling the strike "an extrajudicial execution prohibited by the International Covenant on Civil and Political Rights"); Thomas Haidon, The CIA's Yemen Operation: A Legal Critique, COUNTERPUNCH, Nov. 19, 2002, http://www.counterpunch.org/ haidon11 19.html (arguing that the U.S. attack in Yemen was illegal). 
government's executive branch cannot kill a criminal suspect in lieu of arresting and trying her.

Here again, I think there is no single "legal" answer. The approach taken by Amnesty International rests on a traditional, if formalistic, reading of the law of armed conflict; the approach of the U.S. also rests on a plausible, if flexible, reading of the law of armed conflict ${ }^{167}$ and the U.N. Charter. ${ }^{168}$ The policy choice made by the Bush administration can nonetheless be questioned and criticized, however, for just as the breakdown of the boundaries between crime and conflict has potentially staggering implications, so too does the breakdown of the spatial boundaries between zones of conflict and zones of peace. If there is no place on earth where the U.S. cannot legitimately use military force at any time, without warning, other states will claim the same rights, and we risk an escalating spiral of unconstrained violence-precisely what the creators of the U.N. Charter system sought to avoid. ${ }^{169}$

${ }^{167}$ Unlike Amnesty International, Human Rights Watch took this position, expressing concern about the Yemen attack and its implications, but acknowledging that the Bush administration's assertions about the applicability of the laws of armed conflict represented an "arguably appropriate use of war rules." See Kenneth Roth, Drawing the Line: War Rules and Law Enforcement Rules in the Fight Against Terrorism, in HUMAN RIGHTS WATCH, WORLD REPORT 2004 177, 183, available at http://hrw.org/wr2k4/ 9.htm\#_Toc58744958.

${ }_{168}$ As Undersecretary of Defense Paul Wolfowitz put it in an interview with CNN, when asked about other "fronts" in the war on terror: "[W]e've seen a problem in Yemen just now. But it is a huge mistake to think that this is a problem that is isolated to one or two principal fronts, or one or two principal countries. It's a global problem. And ... you need to go after it everywhere ...." Interview with Paul Wolfowitz, Deputy Secretary of Defense, CNN (Nov. 5, 2002) (transcript available at http://www.defenselink.mil/transcripts/2002/t11052002_t1105cnn.html).

${ }_{1699}$ When terrorist suspects are captured far from any traditional "field of battle," somewhat similar problems are raised. In the wake of the abu Ghraib prison scandal, attention has been drawn not only to the so-called "ghost detainees" held in Iraqi prisons at the request of the CIA, but also to the several dozen terror suspects thought to be in CIA detention at secret locations around the globe. See The United States "Disappeared" the CIA's Long-Term "Ghost Detainees," Human Rights Watch (Oct. 2004), at 5-6, available at http://www.hrw.org/backgrounder/usa/us1004/index.htm. Little is known about most of these detainees, other than that they exist; many were apparently captured in covert actions in countries with which the United States is at peace, such as Pakistan. Id. at 8 . It is difficult to know which legal regime should govern the treatment of these detainees, since we know neither where they were captured nor where they are held. Here too, it is conceivable that the Bush administration could make a legal case for their ongoing detention (although not for their reportedly inhumane interrogation, which sources say involves methods such as almost drowning suspects to make them talk). Id at 7 . But once again, the idea that suspects can be detained indefinitely in undisclosed locations with no judicial or other oversight runs counter to core principles of the rule of law. 
As suggested in the previous section's discussion of the breakdown of the boundary between crime and conflict, this breakdown of spatial boundaries also has potentially breathtaking domestic consequences. If the mere presence of a suspected al Qaeda operative is sufficient to render any place a zone of armed conflict, in which the law of armed conflict trumps other legal regimes, what legal principles would prevent the U.S. government from preemptively killing-on U.S. territory-any U.S. citizen suspected of aiding al Qaeda?

\section{War Without End: Temporal Boundaries}

Only the dead have seen the end of war.

- Douglas MacArthur, May 12, $1962 .{ }^{170}$

The lamps are going out all over Europe: we shall not see them lit again in our lifetime.

- Edward Grey, Aug. 3, 1914. ${ }^{171}$

The laws of armed conflict traditionally conceptualize conflict as bounded temporally as well as spatially. Spatially, there were zones of war, in which the laws of armed conflict applied, and zones of peace, in which ordinary domestic law and international law applied. Temporally, the laws of armed conflict draw a sharp distinction between armed conflict on the one hand, and the "cessation of hostilities"peace-on the other hand. This distinction reflects customary understanding: wars are exceptional events, not the norm; they have a beginning and an end. Some are quite short (the Six-Day War between Israel and Egypt, Jordan, and Syria, for example), and others are relatively long (World War II lasted for six years in Europe). ${ }^{172}$ But in the traditional paradigm, war is clearly defined, marked by the formal sur-

${ }^{170}$ General Douglas MacArthur, Farewell Speech to the Cadets at West Point (May 12, 1962), in A SOLDIER SPEAKS 357 (Major Vorin E. Whan, Jr. ed., 1965) (ostensibly quoting Plato), available at http://www.usconstitution.com/DouglasMacArthur's FarewellSpeech.htm (last visited Oct. 18, 2004).

${ }^{171}$ Sir Edward Grey made this famous remark on the eve of Britain's declaration of war against Germany and the beginning of World War I. THE Columbia WorLd OF QUOTATIONS (Robert Andrews et al. eds., 1996), available at http://www.bartleby.com/ 66/82/26082.html (last visited Oct. 18, 2004).

${ }^{172}$ I am not counting the Thirty Years' War or the Hundred Years' War, because each took place prior to the development of the modern law of armed conflict, and because these appellations are mainly metaphorical descriptions used by historians, and are not literal descriptions. 
render of the defeated parties or by an armistice or other peace agreement. Thus, we celebrate "V.E. Day" or "Armistice Day" to memorialize the end of hostilities. While, as a practical matter, hostilities sometimes continue for a short time after the "end" of a war (in World War II, some isolated groups of soldiers did not receive word of the war's end until weeks or even months later, and therefore kept fighting even after the formal end of the war), ${ }^{173}$ as a legal matter, wars end when the opposing parties formally agree to stop fighting.

Here again, the "war on terrorism" renders the traditional temporal distinctions between war and peace less salient. It is not simply that we do not know when the war on terror will end; no one, during a war, can ever say with certainty just when the war will end, and prewar prognostications are often badly off-base. It is that by its nature, the war on terrorism is unlikely ever to end. Since the enemy in the war on terrorism is shadowy and shifting, and since it seems overwhelmingly likely that the U.S. will face terrorist threats for decades to come, even if all currently living al Qaeda members are apprehended or killed, there is no obvious point at which the U.S. will be able to declare victory and end the conflict. For that matter, since al Qaeda is not a state, it is not obvious that al Qaeda can formally surrender or enter into a peace agreement. And since we apparently lack any means of formal communication with al Qaeda's leadership-assuming al Qaeda even has a command hierarchy similar to that of a state or regular army-there is no clear way to negotiate with al Qaeda even if we wanted to do so. What this means is that we today face the literal prospect of war without end.

The erosion of the temporal boundaries between war and nonwar has particular significance for prisoners of war and other detainees. Although POWs are immunized for their actions as combatants, they can be lawfully detained by opposing forces, and kept in detention until the end of the war. "[A]fter the cessation of active hostilities," however, the Third Geneva Convention requires that they be "released and repatriated without delay." ${ }^{174}$ So far, as will be discussed below, the U.S. has declined to grant POW status to detainees of the

${ }^{179}$ Consider Second Lieutenant Hiroo Onoda of the Japanese Army, who, convinced that the Second World War was not over, remained on Lubang Island in the Philippines awaiting the return of Japanese forces for nearly thirty years. He finally accepted an order to stop fighting in 1974. HIROO ONODA, NO SURRENDER: MY THIRTY-YEAR WAR 11-14 (Charles S. Terry trans., 1974).

${ }^{174}$ Third Geneva Convention, supra note 10, art. 118, 6 U.S.T. at 3406. 
war on terror. ${ }^{175}$ But should the U.S. or other nations detain lawful enemy combatants in the course of the war on terrorism and declare them to be prisoners of war, they should release and repatriate these captives after the cessation of hostilities. If there is no point at which hostilities have unequivocally ceased, however, there is no point at which prisoners of war can expect to be released, and they might find themselves trapped in limbo indefinitely. ${ }^{176}$

In practice, this is the fate of the hundreds of detainees now held at the U.S. military base in Guantanamo, Cuba. ${ }^{177}$ Although the U.S. government insists that the detainees are unlawful combatants rather than prisoners of war with combatant immunity, and that it therefore has the legal right to try and punish the detainees in military tribunals, it only recently initiated proceedings to try any of the detainees (and has announced plans to try only a tiny handful of the more than six hundred still detained). ${ }^{178}$ If there were any way to predict a clear end to the war on terrorism, the U.S. would likely either try the detainees, release them as part of some peace agreement, or some mix of the two. ${ }^{179}$ As it stands, however, the indefinite nature of the conflict means that these detainees may remain in detention indefinitely,

${ }^{175}$ But see Rasul v. Bush, 124 S. Ct. 2686 (2004) (holding that federal district courts have the authority to hear applications for habeas corpus by Guantanamo Bay detainees claiming to be held in custody in violation of the U.S. Constitution, treaties, or laws).

${ }^{76}$ See, e.g., Michael C. Dorf, What Is an "Unlawful Combatant," and Why It Matters: The Status of Detained Al Qaeda and Taliban Fighters, FINDLAW, Jan. 23, 2002, at http://writ.news.findlaw.com/dorf/20020123.html (explaining that even if detainees were accorded prisoner of war status, they might never be entitled to release because the Geneva Conventions' condition of a "cessation of active hostilities" might never be met) (last visited Sept. 8, 2004).

${ }^{177}$ Approximately 680 detainees have been held at Guantanamo; fewer than 100 have been released by arrangement with U.S. allies. See Vernon Loeb, U.S. to Assess Detainees' Cases; Rumsfeld Says Prisoners in Cuba Will Get Annual Reviews, Wash. Post, Feb. 15,2004 , at Al (reporting that more than 90 detainees had been repatriated or released into foreign custody).

${ }^{178}$ The United States has now formally charged two Guantanamo detainees, who will be tried by military commissions. See News Release, U.S. Department of Defense, Two Guantanamo Detainees Charged (Feb. 24. 2004) at http://www.defenselink.mil/ releases/2004/nr20040224-0363.html (last visited Sept. 7, 2004) (announcing that two detainees have been charged with conspiracy to commit war crimes and will be tried by military commission).

${ }^{179}$ The United States has so far released or transferred to allied states some 87 detainees. See Donald H. Rumsfeld, Secretary of Defense, Remarks to Greater Miami Chamber of Commerce (Feb. 13, 2004), at http://www.defenselink.mil/ transcripts/2004/tr20040213-0445.html (last visited Sept. 7, 2004) (stating that 87 of the Guantanamo Bay detainees had been transferred for release and a few had already been returned to their home countries). 
neither charged nor released, ${ }^{180}$ with no access to counsel ${ }^{181}$ and no international or judicial monitoring of conditions. ${ }^{182}$ After several years of intensifying international criticism, the Defense Department recently began to provide Guantanamo detainees with "administrative reviews" to determine whether or not they are unlawful combatants. The reviews involve little process, however, and detainees are not entitled to lawyers. ${ }^{183}$

The disintegration of the temporal boundaries distinguishing times of war from times of peace has other implications as well. As later sections of this article will discuss, there are many kinds of gov-

${ }^{180}$ On February 13, 2004, Secretary of Defense Donald Rumsfeld announced that an administrative review panel would be created to evaluate annually whether each Guantanamo detainee poses an ongoing threat. See id. (explaining the implementation of an annual review board and outlining the review process). The Department of Defense initially declined to give further details, such as whether it would allow detainees counsel in conjunction with review panel hearings, when the first review panels would convene, who would sit on the panels, or whether there would be any appeal from review panel decisions. See Butler, supra note 122 (explaining that details about the composition and authority of the review panel were "under active consideration" but not yet finalized). On March 3, 2004, The Defense Department released some further details, but emphasized that the review process was being created "solely as a matter of discretion," and not in acknowledgment of any legal rights of the detainees. See News Release, U.S. Department of Defense, DoD Announces Draft Detainee Review Policy (Mar. 3, 2004) (detailing in a draft memorandum the proposed administrative review process while emphasizing its discretionary nature), available at http:// www.dod.gov/releases/2004/nr20040303-0403.html (last visited Sept. 7, 2004).

${ }^{181}$ See generally Jesselyn A. Radack, United States Citizens Detained as "Enemy Combatants": The Right to Counsel as a Matter of Ethics, 12 WM. \& MARY BILL RTS. J. 221 (2003) (analyzing the right to counsel of enemy combatants who are U.S. citizens through the lens of the cases regarding Jose Padilla and Yaser Hamdi). The Bush administration argued that the Guantanamo detainees had no right of access to US courts, asserting that US courts lack jurisdiction over Guantanamo. In Rasul v. Bush, decided in June 2004, the Supreme Court rejected this assertion, and stated that Guantanamo detainees could bring habeas claims and various civil suits in U.S. courts. 124 S. Ct. 2686 (2004). So far, however, the Bush administration has refused to allow most detainees access to counsel, rendering the Rasuldecision toothless for the time being.

${ }^{182}$ The only monitoring so far has been done by the ICRC, which normally does not make its observations public and instead works privately to improve conditions if necessary. In this case, however, the ICRC broke with its usual traditions and publicly criticized the U.S. treatment of Guantanamo detainees. See Red Cross: Deteriorating Conditions at Guantanamo, CNN.COM, Oct. 10, 2003, at http://www.cnn.com/ 2003/WORLD/americas/10/10/redcross.guantanamo.ap (last visited Sept. 7, 2004) (reporting the ICRC's vocal concern for the lack of due process accorded to detainees, their deteriorating health, and the Bush administration's lack of responsiveness).

${ }^{183}$ See Jess Brevin, Guantanamo Defense Lawyers Are Barred from Status Hearings; Military Will Determine Whether the Detainees Are 'Enemy Combatants,' WALL ST. J., Sept. 17, 2004, at A8 (reporting that the Pentagon has barred attorneys from representing prisoners in their combatant hearings). 
ernment actions, both domestic and international, that might be tolerable for a finite period of time, but that would be intolerable were they to last forever. ${ }^{184}$

\section{E. We Are All at War: Distinctions Between Persons}

The war on terrorism has also eroded the already problematic distinctions between various categories of persons. The boundary between civilians and combatants is one of the oldest and most hallowed distinctions in the law of armed conflict. Although civilians can sacrifice their right to the protection of the law of armed conflict by taking part in the hostilities (as spies, saboteurs, or partisans, for instance), they are normally protected in times of war. The law of armed conflict prohibits the intentional targeting of civilians, and Common Article 3 of the Geneva Conventions implicitly makes this prohibition applicable even to those armed conflicts "not of an international character": it declares that parties to the conflict must refrain from "violence to life and person, in particular murder of all kinds, mutilation, cruel treatment and torture" with regard to "persons taking no active part in the hostilities." ${ }^{185}$ Failure to respect this general prohibition against the intentional targeting of civilians constitutes a war crime. Depending on whether a conflict is "international" or "internal," civilians also benefit from a range of other protections. ${ }^{186}$

Needless to say, there have been longstanding debates about the definition of "civilian" and the meaning of the phrase "taking no active part in the hostilities." Different states have adopted slightly different approaches, with the debate revolving around questions such as whether civilians working in munitions plants can be permissibly targeted, whether civilians working in television stations used by enemy

${ }^{184}$ As George Orwell wrote in his novel 1984, "[w] hen war is continuous there is no such thing as military necessity. Technical progress can cease and the most palpable facts can be denied or disregarded. . . A peace that was truly permanent would be the same as a permanent war." GEORGE ORWELL, 1984, at 163-64 (Signet Classic 1992) (1949), quoted in Alejandra Rodriguez, Comment, Is the War on Terrorism Compromising Civil Liberties? A Discussion of Hamdi and Padilla, 39 CAL. W. L. REv. 379, 394 (2003).

${ }^{185} 1949$ Geneva Conventions, supra note 10, art. 3, 6 U.S.T. at 3116-18, 3220-22, 3318-20, 3518-20, 75 U.N.T.S. at 32-34, 86-87, 135-38, 288-90.

${ }^{186}$ See Protocol II, supra note 43, 1125 U.N.T.S. at 609 (extending the protections of Protocol I to victims of noninternational conflicts); Protocol I, supra note 43, 1125 U.N.T.S. at 4 (setting protocols for civilian treatment during armed conflicts); 1949 Geneva Conventions, supra note 10, 6 U.S.T. at $3114,3217,3316,3516,75$ U.N.T.S. at $31,85,135,287$ (establishing baseline human rights guarantees for situations of armed conflict). 
states for propaganda purposes can be targeted, whether civilian employees of the military can be targeted, and so on.

To some extent, commentators have also questioned the basic analytic assumptions embedded in the distinction between civilians and combatants: the distinction appears to assume that uniformed combatants can be targeted because their sole and inherent professional purpose is to cause harm to the enemy, and they do in fact cause direct harm to the enemy, while civilians either cause no harm to opposing forces or cause only indirect harm.

This distinction, too, rests on certain anachronistic assumptions about the nature of armed conflict. If the paradigmatic battle imagined by the framers of the Geneva Conventions was one fought by opposing uniformed armies on a large plain, with civilians tucked away safely far behind the front lines, it made sense to posit a clear distinction between civilians and combatants. In fact, even the battles of the nineteenth century rarely fit this paradigm, and modern conflict fits this paradigm still less well. In guerilla warfare, combatants deliberately seek to blend into the civilian population. Even in modern conflicts that do not involve guerilla fighters, civilians not only produce the foods and supplies that keep armies going, they also create and maintain the technologies of war. They may vote for politicians who favor particular wars or wartime policies, or give money to support such policies. Civilian computer technicians thousands of miles away from battlefields may work side by side with uniformed soldiers to program and troubleshoot missile guidance or military communication systems. And with modern technologies such as long-range missiles and unmanned missile-bearing planes, the distance between the "front" and the "rear," if such terms remain meaningful at all, may be half the globe.

Furthermore, the distinction between "directly" and "indirectly" causing harm to an opposing party is mainly artificial. It is not obvious that there is any moral distinction, for instance, between an avid civilian supporter of Slobodan Milosevic's ethnic cleansing policies (who voted for Milosevic and perhaps donated money to his causes) and a young conscript in Milosevic's army. The civilian may have taken active steps to further and support Milosevic's brutal policies, but would still be entitled to protected status under the laws of armed conflict. The military conscript might actively oppose Milosevic and seek to avoid participation in combat, but he would be a legitimate target of opposing forces. 
The war on terrorism renders the lines between civilians and combatants still more incoherent. Terrorists generally do not work for a state. Like guerilla fighters, they do not wear uniforms or openly acknowledge their identities, and they seek to blend in with civilian populations.

Moreover, many terrorists may never play any "direct" role in attacks. Of course, Mohammed Atta and the other eighteen September 11 hijackers clearly engaged in acts of direct violence against the United States, and if we use a law of armed conflict paradigm, rather than a criminal law paradigm, to address September 11, it would clearly have been lawful for the U.S. to have tried Atta for war crimes had he survived. Likewise, if there is an armed conflict between the U.S. and al Qaeda, it is lawful for the U.S. to target al Qaeda operatives actively engaged in attacks on the U.S.-in Yemen or anywhere else. But what about the dozens or thousands of people around the world who are al Qaeda sympathizers and supporters, yet have no formal "rank" or title, and whose support never comes close to engaging in actual violence? Is an American clerk who obtained false identification for a September 11 hijacker a civilian, or a combatant? Would it matter if she was unaware of the planned attacks, but sympathized with al Qaeda's broader aims? Were the wives of the married September 11 hijackers civilians or combatants? Are employees of charitable organizations that allow some funds to be diverted to al Qaeda combatants or civilians? Applying the law of armed conflict to terrorism, there is no obvious way to decide.

The distinction between civilians and combatants is somewhat analogous to another important distinction between persons: the distinction between lawful and unlawful combatants. Lawful combatants are immunized for their acts of violence during the conflict, assuming those acts of violence otherwise comport with the law of armed conflict. If captured, they must be treated as prisoners of war. They cannot be punished, and they must be released at the end of the conflict. Unlawful combatants, in contrast, are combatants who in one way or another violate the law of armed conflict, either by failing to comply with formal definitions of lawful combatants or by committing a war crime. If unlawful combatants are captured, they may be tried and punished, either by regular courts or by military tribunals. ${ }^{187}$

${ }^{187}$ For example, see Ex parte Quirin, 317 U.S. 1 (1942), in which the Supreme Court declared that a "universal agreement and practice" under "the law of war" holds that "[1] awful combatants are subject to capture and detention as prisoners of war by opposing military forces" and "[u]nlawful combatants are likewise subject to capture 
Under the law of armed conflicts, to be considered "prisoners of war," combatants who are members of militias or other volunteer corps must be "commanded by a person responsible for his subordinates," have a "fixed distinctive sign recognizable at a distance" (e.g, a uniform, banner, or other sign by which combatants can be distinguished from civilians), and "[carry] arms openly," in addition to otherwise complying with "the laws and customs of war."188 The Bush administration has apparently interpreted this to mean that all al Qaeda operatives are inherently unlawful combatants, since they neither wear uniforms nor carry arms openly. ${ }^{189}$ As a result, the Bush administration has refused to grant prisoner of war status to any of the hundreds of people currently detained at Guantanamo Bay. The Bush administration has also insisted that members of the Taliban fighting forces captured during the fighting in Afghanistan are similarly not lawful combatants, evidently on the grounds that Taliban fighters wore no uniforms and did not always bear arms openly. ${ }^{190}$

and detention, but in addition they are subject to trial and punishment by military tribunals for acts which render their belligerency unlawful." Id. at 30-31.

${ }^{188}$ Third Geneva Convention, supra note 10 , art. 4, 6 U.S.T. at $3320-22,75$ U.N.T.S. at 138-40. The Geneva Convention states that members of regular state armed forces are lawful combatants. Id. Even though, under Article 4, the above requirements (command by a responsible person, a fixed sign, open carrying of weapons, and compliance with the laws and customs of war) technically apply only to "[m] embers of other militias and members of other volunteer corps" by custom, those requirements apply to all combatants, including combatants with regular armies. Id.; see also Omar Akbar, Note, Losing Geneva in Guantanamo Bay, 89 IOWA L. REV. 195, 218 (2003) (noting that "customary law" requires compliance with the four requirements of Article 4 even for members of regular armed forces).

${ }^{189}$ See Goldman \& Tittemore, supra note 7, at 25; see also Lawrence Azubuike, Status of Taliban and al Qaeda Soldiers: Another Viewpoint, 19 CONN. J. INT'L L. 127, 14654 (2003) (describing the argument against extending combatant status to members of the Taliban and al Qaeda); U.S. Defends Handling of Afghan Captives, BBC NEwS ONLINE, Jan. 12, 2002, at http://news.bbc.co.uk/1/hi/world/americas/1756643.stm (quoting U.S. Defense Secretary Rumsfeld as saying the Taliban and al Qaeda captives will "be handled . . . as unlawful combatants"); Ari Fleischer, White House Press Secretary, Press Briefing (Feb. 7, 2002), at http://www.whitehouse.gov/news/releases/ 2002/02/20020207-6.html ("[T] he national security team . . . has always said that these detainees should not be treated as prisoners of war, because they don't conform to the requirements of Article 4 of the Geneva Convention ....").

${ }^{190}$ The U.S. Ambassador-at-Large for War Crimes Issues, Pierre-Richard Prosper, has declared that the members of the Taliban "are not under a responsible command," that they do not "conduct their operations in accordance with the laws and customs of war," that they do not have a "fixed distinctive sign recognizable from a distance," and that they do not "carry arms openly." Pierre-Richard Prosper, Status and Treatment of Taliban and al-Qaida Detainees, Remarks at Chatham House, London, United Kingdom (Feb. 20, 2002), at http://www.state.gov/s/wci/rm/2002/8491.htm. "Their conduct and history of attacking civilian populations, disregarding human life and con- 
The administration has also argued, with regard to both al Qaeda and Taliban detainees, that since neither the Taliban, as such, nor al Qaeda, as such, abide by "the laws and customs of war," all members of both groups are unlawful combatants. ${ }^{191}$

These arguments have been challenged by a range of commentators, from human rights groups and scholars to foreign diplomats and military lawyers. ${ }^{192}$ With regard to al Qaeda detainees, the administration's case is strong, but it nevertheless seems problematic to declare, by fiat, that all suspected al Qaeda members are unlawful combatants. Hypothetically, some al Qaeda supporters might claim to have worn recognizable signs or to have carried arms openly, and Article 5 of the Geneva Convention on Prisoners of War requires that "[s] hould any doubt arise as to whether persons, having committed a belligerent act and having fallen into the hands of the enemy ... [are lawful combatants], such persons shall enjoy the protection of the present Convention until such time as their status has been determined by a competent tribunal." ${ }^{193}$ However, the United States has held no Article 5 hearings to determine the status of Guantanamo detainees. ${ }^{194}$

ventional norms, and promoting barbaric philosophies represents firm proof of their denied status." Id.; see also Diane K. Hook, Detainees or Prisoners of War?: The Applicability of the Geneva Convention to the War on Terrorism, 58 J. Mo. B. 346, 348-49 (2002) (asserting that the Taliban did not meet "all of the four conditions for belligerent status"), available at http://www.mobar.org/journal/2002/novdec/hook.htm.

${ }^{191}$ See Azubuike, supra note 189, at 146 (quoting a U.S. ambassador on the issue of the Geneva Convention's criteria pertaining to "the laws and customs of war").

The United States initially took the position that the Geneva Conventions did not cover the Taliban soldiers captured in the conflict. The proffered justification was that "since Afghanistan was not a functioning state during the conflict and the Taliban was not recognized as a legitimate government, Afghanistan did not continue as a party to the Third Geneva Convention, which therefore could not apply to members of the Taliban." Id. at 145 (internal quotation marks omitted). Realizing the shaky premises of such a contention, the United States amended its position by asserting the more plausible view that since both the United States and Afghanistan were parties to the Geneva Conventions, and there was an armed conflict between the two, Geneva III applied. However, it determined "that the Taliban's actions in violating the laws of war and closely associating itself with Al Qaeda had the effect of stripping Taliban members of their rights to prisoner of war status." Id. at 145 (internal quotation marks omitted).

${ }^{192}$ See generally Akbar, supra note 188 (providing a detailed critique of the Bush administration's politics toward detainees).

${ }^{193}$ Third Geneva Convention, supra note 10, art. 5, 6 U.S.T at 3322,75 U.N.T.S at 140 .

94 See LAWYERS COMM. FOR HUMAN RIGHTS, supra note 11, at 54 ("In the absence of individualized Article 5 hearings ... there is genuine concern that noncombatants may have been caught up in the Guantánamo net."). The failure of the United States to hold Article 5 hearings has been widely criticized, even by many senior military offi- 
The administration's case for regarding Taliban detainees as per se unlawful combatants is weaker. The Taliban was Afghanistan's de facto government, and its armed forces were thus a regular army. For the most part, Taliban forces did carry arms openly, and while they wore no uniforms in the Western sense, apparently they normally wore distinctive black turbans. ${ }^{195}$ The Taliban allegedly committed numerous violations of the laws and customs of war (for example, targeting civilians), but as the Lawyers Committee for Human Rights has noted, “[ $\mathrm{t}]$ he blanket labeling as 'unlawful' of an entire nation's regular army because of a practice of even widespread war crimes is unprecedented." ${ }^{196}$ As with the al Qaeda detainees, the United States has not afforded any of the Taliban detainees at Guantanamo Bay Article 5 hearings to determine their status. ${ }^{197}$

It should be noted that the rules for determining the lawfulness or unlawfulness of a combatant are themselves archaic and arguably biased in favor of wealthier armies. The notion that "lawfulness" might hinge, for instance, on the wearing of "fixed distinctive signs" is odd; again, the classic paradigm, with its images of bugles and banners, does not accord well with the realities of modern conflicts, in which the rag-tag soldiers of third-world states and militias may simply lack the resources to wear anything resembling a uniform. Here, the law of armed conflict offers a set of chivalric rules that favors those with more resources. $^{198}$

cials. Some of the detainees will ultimately stand trial in military commissions; as of March 1, 2004, however, only two of the hundreds of remaining detainees had been charged. See News Release, supra note 178 (announcing the charges against two detainees).

:95 See LAWYERS COMM. FOR HUMAN RIGHTS, supra note 11, at 109 n.424 (referencing sources that describe the Taliban uniform, including black turbans).

${ }^{196}$ Id. at 54.

${ }^{197}$ Id. The recent U.S. decision to release more than eighty Guantanamo detainees appears to be a de facto acknowledgment that in some cases the administration was mistaken about the role the detainees had played. See Loeb, supra note 177, at A20 (reporting that a panel would look at intelligence on the detainees before recommending whether they should be released).

198 Interestingly, on a nonformalist reading of the Geneva Conventions, it could also be argued that some of the high tech weapons systems possessed by the United States and other wealthier nations risk turning some U.S. military personnel into "unlawful combatants." The requirements that combatants have "fixed distinctive signs recognizable at a distance" and that they "carry arms openly" were presumably intended both to clearly distinguish combatants from civilians and to eliminate "treacherous killings." Could the U.S. personnel who program and control unmanned aircrafts, such as the predator drone that fired Hellfire missiles to kill al Qaeda suspects in Yemen, be considered lawful combatants? See, e.g., Jack Kelley, U.S. Kills al-Qaeda Suspects in Yemen, USA TODAY, Nov. 5, 2002, at 1A (reporting the November 2002 assas- 
In the war against terrorism, the U.S. has so far insisted that it recognizes no lawful enemy combatants at all. ${ }^{199}$ This position also has troubling and far-reaching implications. The U.S. government has detained U.S. citizens as "unlawful combatants," tained foreign children as young as thirteen at Guantanamo. ${ }^{201}$ The refusal of the U.S. government to place limits on the categories of people who may be detained indefinitely-without being charged and without any of the protections accorded either to POWs or to criminal defendants-is worrisome, particularly in the absence of clear spatial or temporal limits to the war on terror. ${ }^{202}$

The increasing blurriness of the distinction between lawful and unlawful combatants has also created a slippery slope problem. The Bush administration has used the genuine ambiguity about what rules should govern which persons to assert that there is also ambiguity over whether detainees can subjected to interrogation methods such as hooding, sleep deprivation, use of dogs, sensory deprivation, nudity, and the placement of prisoners in painful positions for extended pe-

sination of wanted al Qaeda operative Ali Qaed Sinan al-Harth and five associates by the CIA). (In fact, the aircraft was apparently operated by the CIA, but even if operated by the military, the same question might be asked.) Id.

${ }^{199}$ Under intense pressure, the Pentagon grudgingly agreed that the Geneva Conventions apply to the conflict in Iraq-a classic international armed conflict-making all detainees in Iraq either POWs covered by the Third Geneva Convention or civilians covered by the Fourth.

${ }^{200}$ See LAWYERS COMM. FOR HUMAN RIGHTS, supra note 11, at ii-jii (discussing the detention of Yaser Hamdi and Jose Padilla, both U.S. citizens). See generally ABA Task Force on Treatment of Enemy Combatants, Preliminary Report, Aug. 8, 2002, at 3 (expressing concern about recent government actions implying that "with no meaningful judicial review, any American citizen alleged to be an enemy combatant could be detained indefinitely without charges or counsel on the Government's say-so." (quoting Hamdi v. Rumsfeld, 337 F.3d 335, 358 (4th Cir. 2003), vacated and remanded by 124 S. Ct. 2633 (2004))).

${ }^{201}$ On January 29, 2004, U.S. authorities released and repatriated three children, aged thirteen to fifteen, after holding them as enemy combatants for nearly two years; U.S. officials have acknowledged that other detainees aged sixteen and seventeen remain in detention. News Release, U.S. Department of Defense, Transfer of Juvenile Detainees Completed (Jan. 29, 2004), available at http://www.dod.mil/releases/2004/ nr20040129-0934.html (describing the detention and release of three juveniles from Guantanamo); News Release, Human Rights Watch, U.S.: Despite Releases, Children Still Held at Guantanamo (Jan. 29, 2004), at http://www.hrw.org/english/docs/ 2004/01/29/usint7117.htm ("The Department of Defense has confirmed that an unspecified number of other children, aged 16 and 17 , are also detained at Guantanamo.").

${ }^{202}$ See generally Michael Greenberger, Is Criminal Justice a Casualty of the Bush Administration's "War on Terror"?, 31 HUM. RTS. 19 (2004) (describing the dangers of government prosecutions that seek to fight terrorism). 
riods. In fact, international law makes it clear that torture and cruel or inhumane treatment of detainees is prohibited regardless of the detainees' status. ${ }^{203}$

\section{F. The Boundaries Between National Security and Domestic Affairs}

Inter armes, silent legis. [In time of war, the law is silent].

- Cicero $^{204}$

If recent events have rendered less and less coherent many of the time-honored distinctions drawn by the law of armed conflict, they have had a similar impact on the customary domestic jurisprudential distinction between matters affecting "national security" and matters that are entirely domestic in nature. As discussed in Part II, U.S. courts have traditionally granted far greater deference to the government (particularly the executive branch) when national security is at stake. On the whole, U.S. courts have effectively accorded the government something roughly analogous to "combatant immunity" when it comes to actions taken in furtherance of national security. Thus, courts have generally permitted government restrictions on individual liberties in response to wars and other urgent threats to national security, even when the same restrictions would not have been permissible absent such national security justifications.

This judicial deference rests in part on structural assumptions derived from the Constitution. Congress and the executive are jointly charged with carrying out foreign and military affairs, ${ }^{205}$ and the judiciary has generally taken the view that these branches of government are far better placed than the judiciary to make the difficult judgments called for in "external" matters, ${ }^{206}$ particularly those that relate to national security threats (including judgments as to the very existence of a threat). The President, as Commander-in-Chief, is therefore accorded particular deference when it comes to matters affecting the security of the nation.

203 See supra notes 10-20 and accompanying text.

${ }^{204}$ Quoted in REIINQUIST, supra note 5, at 218.

${ }^{205}$ See U.S. CONST. art. I, $\$ 8$ (enumerating Congress's powers); id. art. II, $\$ 2$ (establishing, among other powers, the President's role in foreign and military affairs).

${ }^{206}$ See, e.g., United States v. Curtiss-Wright Exp. Corp., 299 U.S. 304, 315 (1936) ("The whole aim of the resolution [in question] is to affect a situation entirely external to the United States."). 
The traditional judicial willingness to defer to government judgments on national security issues also derives from something else, however: the assumption that cases involving national security matters will be the exception, rather than the norm. This assumption makes intuitive sense. Courts always engage in balancing tests when evaluating government incursions on individual rights, and when the government interest in infringing on protected rights is particularly urgent, courts may legitimately feel that this urgency tips the balance in favor of the government. There are many restrictions on individual rights that may be necessary and tolerable on an emergency basis, provided that they do not go on indefinitely. ${ }^{207}$

Like the distinctions drawn by the law of armed conflict, the distinction between national security and internal affairs has always been contested. At times, courts have subjected government actions undertaken in the name of national security to great scrutiny and refused to uphold them. More often, though, the courts have deferred to the government, although scholars and activists have always challenged these court decisions. ${ }^{208}$ History strongly suggests, however, that deference to government claims of national security imperatives has often led courts to uphold government actions that in hindsight appeared unjustified. Indeed, history has revealed numerous cases in which government officials have knowingly misrepresented the nature of the threat to the courts. ${ }^{209}$

${ }^{207}$ Especially if there is some later remedy for those whose interests were greatly damaged. Consider, for instance, the possibility of mandatory vaccinations-or quarantines-in the event of a smallpox outbreak.

${ }^{208}$ Cf. Gross, supra note 66, at 1034 (discussing courts' "highly deferential attitude" in reviewing governmental actions and decisions in emergency situations).

${ }^{209}$ In Korematsu v. United States, 323 U.S. 214 (1944), for instance, it later became apparent that U.S. officials had knowingly misinformed the court about evidence relating to the dangerousness of Japanese Americans. See Susan Kiyomi Serrano \& Dale Minami, Korematsu v. United States: A "Constant Caution" in a Time of Crisis, 10 AsIAN L.J. 37, 37 (2003) ("Unearthed documents had revealed that no military necessity existed to justify the incarceration, and that government decision makers knew this at the time, and later lied about it to the Supreme Court."). More recently, several Bush administration prosecutions of suspected terrorists have collapsed in the face of evidence that prosecutors exaggerated the evidence. See Botched Terror Cases Are Evidence of Overzealous Prosecution, supra note 92, at 10A ("In some cases, the blame lies with sloppy work by prosecutors. In others, the government appears to have been over-eager to declare it had bagged a terrorist and allowed due process to fall by the wayside."); Dan Eggen, Report Scolds Terrorism Prosecutors: U.S. to Drop Convictions About Trio in Detroit, WASH. POST, Sept. 2, 2004, at A03 ("[T] he report raises serious questions about the veracity of most of the key evidence and testimony at the heart of the [Detroit sleeper cell] case."); Parker, supra note 92, at A1 ("Military prosecutors who accused an Air Force translator ... of taking part in a spy ring that tried to pass more than 200 secret 
The new U.S. "war on terrorism" is rendering judicial efforts to distinguish between national security cases and "ordinary" domestic issues ever more difficult, so much so that judicial line-drawing efforts appear almost completely arbitrary. If all acts of terrorism-or acts of support for terrorism-constitute acts of war, and if the war on terror has neither spatial nor temporal boundaries, then arguably almost anything might be said to implicate national security concerns, including actions that would ordinarily be construed as simple crimes. Thus, the government has argued that even U.S. citizens who are suspected of aiding al Qaeda can be detained and held indefinitely as unlawful enemy combatants rather than charged with a crime and offered the usual protections constitutionally guaranteed to all criminal suspects.

In Hamdi v. Rumsfeld, ${ }^{210}$ the Supreme Court struggled to address these arguments in the context of the detention of U.S. Citizen Yaser Hamdi. According to the government, Hamdi was detained by U.S. allies in the Northern Alliance during the war in Afghanistan and subsequently handed over to U.S. authorities. ${ }^{211}$ The Department of Defense designated Hamdi an "unlawful combatant," and detained him without charge beginning in $2001 .^{212}$ In 2003, the Fourth Circuit upheld the government's detention of Hamdi, citing the Supreme Court's traditional "great deference to the political branches when called upon to decide cases implicating sensitive matters of foreign policy, national security, or military affairs," ecutive "is best prepared to exercise the military judgment attending the capture of alleged combatants." ${ }^{214}$ To the Fourth Circuit, a twopage affidavit from a Defense Department civilian official asserting that Hamdi was an unlawful combatant was deemed sufficient to justify his indefinite detention without charge, access to counsel, ${ }^{215}$ or any opportunity to challenge the government's factual assertions. ${ }^{216}$

documents to U.S. enemies now say that only one of the documents was secret ..."); Editorial, The Spies Who Weren't, WASH. POST, Oct. 6, 2004, at A26 ("Over the past few months, three espionage or security-related cases against personnel at the [Guantanamo] base have fallen apart.").

210124 S. Ct. 2633 (2004).

211 LAWXERS COMM. FOR HUMAN RIGHTS, supra note 11, at 63.

212 Id.

${ }^{213}$ Hamdi v. Rumsfeld, 316 F.3d 450, 463 (4th Cir. 2003), vacated by 124 S. Ct. 2633 (2004), remanded to 378 F.3d 426 (4th Cir. 2004) (quoting Harndi v. Rumsfeld, 296 F.3d 278, 281 (4th Cir. 2002)).

${ }_{215} I d$. at 472 (quoting Hamdi, 296 F.3d at 283).

${ }^{215}$ The Department of Defense subsequently decided to permit both Jose Padilla and Yaser Hamdi access to counsel, but in the case of both men the Defense Department insisted that access was being granted not as a matter of legal right but "as a mat- 
The Supreme Court was less willing than the Fourth Circuit to defer wholly to the government, but the Justices were unable to agree on much beyond the notion that U.S. citizens retain at least some rights even in times of war. On the one hand, the Court issued a stinging reprimand to the Bush administration, insisting that "a state of war is not a blank check for the President when it comes to the rights of the Nation's citizens," and declaring that Yaser Hamdi had to be permitted to challenge his detention. ${ }^{217}$ On the other hand, the Court did not say specifically how Hamdi should be permitted to challenge his detention, commenting merely that "a citizen held in the United States as an enemy combatant [must] be given a meaningful opportunity to contest the factual basis for that detention before a neutral decisionmaker," ${ }^{218}$ leaving open the possibility that Hamdi might be entitled only to a sort of "due process lite." A wide range of questions result: should Hamdi and others similarly situated be able to crossexamine witnesses and consult freely with counsel? What should be the standard of proof needed to hold a person as an enemy combatant? What constitutes a "neutral decisionmaker"? Would an alleged enemy combatant who failed to persuade a "neutral decisionmaker" of her innocence be entitled to appeal, and if so, to whom? Despite the ringing rhetoric in Justice O'Connor's majority decision, the practical effect of Hamdi was to toss the ball back into the executive branch's court, leaving the government free to decide how much due process is enough.

In the related case of Jose Padilla, the Supreme Court similarly passed up an opportunity to decisively rein in executive power. $\mathrm{Pa}$ dilla, like Hamdi a U.S. citizen, was arrested in Chicago in May 2002. ${ }^{219}$ $\mathrm{He}$ was initially held as a federal material witness whose testimony might be relevant to other terrorism-related investigations. ${ }^{220}$ Federal officials told the press that Padilla was in contact with al Qaeda and

ter of discretion and military authority. Such access is not required by domestic or international law and should not be treated as a precedent." News Release, U.S. Department of Defense, Padilla Allowed Access to Lawyer (Feb. 11, 2004), available at http://www.dod.mil/releases/2004/nr20040211-0341.html. What's more, the U.S. Department of Defense refused to allow either of the two men to meet privately with their attorneys, insisting instead on monitoring attorney-client communications. The Illusion of Access, Human Rights Watch (Feb. 27, 2004), at http://www.hrw.org/ english/docs/2004/02/27/usdom7701.htm.

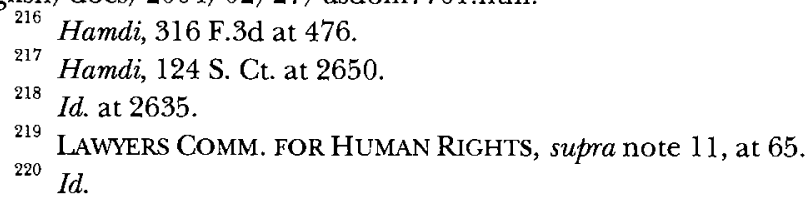


had planned to create a so-called "dirty bomb." A month after his initial detention, the President designated Padilla an "enemy combatant" (and presumptively an unlawful combatant). ${ }^{222}$ Padilla was transferred to military custody where he has remained ever since. The government has not charged Padilla with any crime, has asserted that he has no right to counsel, and has not said whether or not Padilla will eventually face charges before a military commission of any sort. ${ }^{223}$

The District Court of the Southern District of New York ordered the government to give Padilla access to counsel so that he could challenge the evidence on which he had been declared an enemy combatant, although the U.S. government refused to comply with the court's order. $^{224}$ But the district court nevertheless accepted the government's argument that if a U.S. citizen is an enemy combatant, then she can be held indefinitely without charge. ${ }^{225}$ The court agreed that national security concerns merit great deference to the government's judgment of the appropriateness of using the "war" paradigm rather than the "crime" paradigm. ${ }^{226}$ Further, the court agreed that the government need not prove beyond a reasonable doubt that Padilla qualifies as an enemy combatant: according to Judge Michael $\mathrm{Mu}$ kasey, the government need only provide "some evidence" to support such a designation. ${ }^{227}$

The district court's decision was reversed by the Second Circuit Court of Appeals in December 2003. ${ }^{228}$ The Second Circuit refused to defer to the executive branch's determination that Padilla was an "enemy combatant," insisting that the President has no power to declare a U.S. citizen an enemy combatant when the citizen was seized inside the U.S. ${ }^{229}$ The reach of this decision is unclear however. First, the

221 Id.

222 Id.

${ }^{223}$ See id. (recounting the detention of Padilla). Ironically, Padilla and Hamdi have less likelihood than noncitizens of resolving their cases, since, as U.S. citizens, they are not eligible to be tried by a military commission. See News Release, U.S. Department of Defense, supra note 215 ("As a U.S. citizen, Padilla is not eligible for trial by military commission under the President's military order of Nov. 13, 2001.").

${ }^{224}$ Padilla ex rel. Newman v. Bush, 233 F. Supp. 2d 564, 605 (S.D.N.Y. 2002), rev'd sub nom. Rumsfeld v. Padilla, 124 S. Ct. 2711 (2004); see also supra note 215.

${ }^{225}$ Padilla, 233 F. Supp. 2d at 592-96.

226i Id. at 588-90.

${ }^{227}$ Id. at 570 .

${ }^{228}$ Padilla v. Rumsfeld, 352 F.3d 695 (2d Cir. 2003), rev'd and remanded by 124 S. G.t. 2711 (2004).

${ }^{229}$ Id. at 713-18. The court also held that the Non-Detention Act of 1971, 18 U.S.C. $\$ 4001$ (a) (2000), prohibited the detention of American citizens without ex- 
Second Circuit noted explicitly that its holding is not necessarily in conflict with the Fourth Circuit decision in Hamdi, since the Fourth Circuit "directly predicated its holdings on the undisputed fact that Hamdi was captured in a zone of active combat in Afghanistan."230 This limits the holding in Padilla to U.S. citizens detained on U.S. soil.

Furthermore, the Second Circuit based its holding on the principle that inherent executive powers do not extend to the designation of U.S. citizens as enemy combatants when they are captured on U.S. soil. $^{231}$ The Second Circuit suggested, however, that Congress would have the power to authorize such presidential actions: "The Constitution envisions grave national emergencies and contemplates significant domestic abridgements of individual liberties during such times ... . [but] the Constitution lodges these powers with Congress, not the President." ${ }^{232}$ Given congressional compliance in the war on terror-for example the passage of the USA PATRIOT Act in 2001 by a Senate vote of 99-1-this holding does little to limit government prerogatives or safeguard constitutional rights.

The Supreme Court granted certiorari in Padilla, but ultimately declined to rule on the merits, instead reversing and remanding on the grounds that suit had been brought in the wrong jurisdiction. ${ }^{233}$ Logically, if Hamdi (allegedly captured on a foreign battlefield) is entitled at least to an opportunity to contest his detention before a neutral decision maker, then Padilla (detained in Chicago) can surely be entitled to no less. The Court's unwillingness to rule on the merits in Padilla underscores the Court's queasiness about squarely confronting claims of executive power.

The various cases arising out of Guantanamo Bay raise similar questions about the willingness of the judiciary to meaningfully limit government powers in times of national security crisis. ${ }^{234}$ In Al Odah v.

press congressional authorization, and neither Congress's joint resolution, Authorization for Use of Military Force, Pub. L. No. 107-40, 115 Stat. 224 (2001), nor 10 U.S.C. § 956(5) constituted such authorization under 18 U.S.C. $\S 4001$ (a). Padilla, 352 F.3d at $722-24$

230 Padilla, 352 F.3d at 717.

231 Id. at $717-18$.

${ }^{232} I d$. at 714 (citations omitted).

239 Rumsfeld v. Padilla, 124 S. Ct. 2711 (2004).

${ }^{234}$ Gherebi v. Bush, 352 F.3d 1278 (9th Cir. 2003), vacated by 124 S. Ct. 2932 (2004), however, held that the issue of legal "sovereignty" is not controlling, and that by virtue of the United States' exercise of territorial jurisdiction over Guantanamo, federal district courts had jurisdiction over an alleged enemy combatant's habeas petition. This position was endorsed by the Supreme Court in Rasul v. Bush, 124 S. Ct. 2686 (2004). Despite the Supreme Court's recent decision in Rasul, which found that U.S. courts do 
United States, ${ }^{235}$ the plaintiff challenged the constitutionality of the government's detention of hundreds of "enemy aliens" at a U.S. military base in Guantanamo Bay, Cuba. While acknowledging the possibility that the Guantanamo detainees might not in fact qualify as "enemy aliens," 236 the D.C. Circuit dismissed the constitutional challenge for lack of jurisdiction. The D.C. Circuit, holding that the Guantanamo military base is not on U.S. sovereign territory, ${ }^{237}$ relied on Johnson $v$. Eisentrager to assert that "constitutional rights . . are not held by aliens outside the sovereign territory of the United States, regardless of whether they are enemy aliens." versed the D.C. Circuit in Rasul v. Bush, but in a laconic decision that was strictly limited to the jurisdictional question, deferring all substan-

have jurisdiction over Guantanamo, the Court has so far declined to order the U.S. government to provide the Guantanamo detainees with access to counsel.

${ }^{235} 321$ F.3d 1134 (D.C. Cir. 2003), rev'd sub nom. Rasul v. Bush, 124 S. Ct. 2686 (2004) (holding that no U.S. court could grant detainees at Guantanamo habeas relief and that the detainees also had no ability to litigate in U.S. courts).

${ }^{236}$ This acknowledgment rested on something of a technicality; the D.C. Circuit stated that the controlling precedent was Johnson v. Eisentrager, 339 U.S. 762 (1950), and in Eisentrager.

The Court's description of the prisoners as "enemy aliens" rested instead on their status as nationals of a country at war with the United States. . . [I] $t$ follows that none of the Guantanamo detainees are within the category of "enemy aliens," at least as Eisentrager used the term. They are nationals of Kuwait, Australia, or the United Kingdom. Our war in response to the attacks of September 11, 2001, obviously is not against these countries. It is against a network of terrorists operating in secret throughout the world and often hiding among civilian populations. An "alien friend" may become an "alien enemy" by taking up arms against the United States, but the cases before us were decided on the pleadings, each of which denied that the detainees had engaged in hostilities against America.

Al Odah, 321 F.3d at 1139-40.

${ }^{237}$ The court noted that "Cuba-not the United States-has sovereignty over Guantanamo Bay." Al Odah, 321 F.3d at 1143. The D.C. Circuit relied on Cuban Am. Bar Ass'n v. Christopher, 43 F.3d 1412 (11th Cir. 1995) and Vermilya-Brown Co. v. Connell, 335 U.S. 377 (1948), for this holding. The court noted that

[i]n holding that a naval base in Bermuda, controlled by the United States under a lease with Great Britain, was outside United States sovereignty, the Court took notice of the lease with Cuba for the Guantanamo Bay Naval Base and the fact that it granted the United States "substantially the same rights as it has in the Bermuda lease."

Al Odah, 321 F.3d at 1143 (quoting Vermilya-Brown Co., 335 U.S. at 383). The court further noted that the "determination of sovereignty over an area ... is for the legislative and executive departments." Id. (quoting Vermilya-Brown Co., 335 U.S. at 383).

${ }_{238}$ Al Odah, 321 F.3d at 1140-41. The D.C. Circuit noted that in Johnson v. Eisentrager, "the Supreme Court rejected the proposition 'that the Fifth Amendment confers rights upon all persons, whatever their nationality, wherever they are located and whatever their offenses." Id. at 1140 (quoting Eisentrager, 339 U.S. at 783). 
tive questions about the status and treatment of the Guantanamo detainees. ${ }^{239}$

Although rights advocates were relieved by Hamdi, Padilla, and Rasul, it remains unclear whether the Supreme Court will impose any effective limits on government actions in the war on terror. In these three major cases, the Court did little to constrain executive power in practice. In light of past precedents, it seems unwise to predict the dawning of a new era of Court scrutiny of government actions undertaken in the name of national security. Ominously, the Court has denied certiorari in a number of other cases that raise related issues about the limits on government power post-9/11, including Center for National Security Studies v. United States Department of Justice, ${ }^{240}$ North Jersey Media Group, Inc. v. Ashcroft, ${ }^{241}$ and M.K.B. v. Warden, ${ }^{242}$ all of which involved challenges to lower court decisions deferring to government judgments about the need for secrecy in connection with post-9/11 detentions.

The general judicial willingness to defer to the government in these and other recent cases has been widely criticized, ${ }^{243}$ and understandably so-the implication of these decisions is that all barriers between internal and external, international and domestic, war and peace, and crisis and normalcy have broken down, and even the most fundamental constitutional rights may be abrogated by the U.S. government upon a simple claim that the law of war is applicable, rather than ordinary criminal and constitutional law. Nonetheless, troubling though this is, it cannot credibly be claimed that the judicial deference to the government in these recent cases is either irrational or indefensible (as opposed to unwise). The main problem lies not in the government or the judiciary's application of the relevant legal principles. The main problem lies with the legal categories themselves.

${ }^{239}$ Rasul, 124 S. Ct. at 2686.

24031 F.3d 918 (D.C. Cir. 2003), cert. denied, 124 S. Ct. 1041 (2004) (holding that the U.S. Department of Justice was exempted under the Freedom of Information Act's law enforcement exemption from having to disclose the names of detainees and their attorneys).

${ }^{241} 308$ F.3d 198, 219 (3d Cir. 2002), cert. denied, 538 U.S. 1056 (2003) (holding that newspapers do not have a First Amendment right to access deportation hearings that have been determined to present significant national security concerns by the Attorney General).

${ }^{242} 124$ S. Ct. 1405 (2004) (denying certiorari in a case involving the press's right to access habeas proceedings involving the war on terror).

${ }^{243}$ See, e.g., LAWYERS COMm. FOR Human Rights, Assessing THE NEW Normal: LIBERTY AND SECURITY FOR THE POST-SEPTEMBER 11 UNITED STATES, at ii (2003) (criticizing the lack of judicial review regarding the treatment of military prisoners). 


\section{IMPLICATIONS: WAR EVERYWHERE; RIGHTS NOWHERE}

All the boundaries lying between the two worlds of war and non-war, of military and non-military, will be totally destroyed ....

- Qiao Liang \& Wang Xiangui, Unrestricted Warfare ${ }^{244}$

So far, I have argued in this article that the changing nature of international security threats has caused the breakdown of most of the basic distinctions taken for granted by the laws of armed conflict and by that body of domestic U.S. jurisprudence that deals with national security issues. The changing nature of conflict and threat-in particular the rise of global terrorism-has eroded the customary boundaries that separate war and peace, civilians and combatants, lawful and unlawful belligerents, national security issues and domestic issues. As a result, it is becoming more and more difficult to know how to characterize, as a matter of law, the kinds of threats that increasingly face the U.S. and other nations, and it is therefore becoming harder and harder to determine the appropriate legal responses to these threats. The old categories have lost their analytical and moral underpinnings, but we have not yet found alternative paradigms to replace them.

The human rights, civil rights, and international law communities have not squarely confronted this problem. By and large, these communities have been inclined to argue that the Bush administration is wrongly construing and applying the law of armed conflict: e.g., that the government has wrongly categorized Yemen as part of the conflict zone; that it has wrongly characterized the Guantanamo detainees as unlawful combatants rather than prisoners of war; that it has wrongfully categorized the September 11 attacks as an armed conflict rather than a crime, and so on. This critique rests on plausible but formalistic readings of the applicable law. (And ironically, in other contexts, prior to September 11, these same communities have insisted on the importance of flexible and progressive readings of international law, particularly in regard to the law of armed conflict). ${ }^{245}$

This formalist critique overlooks the fundamental underlying problem, however. For the most part, the problem is not that the

${ }^{244}$ QIAO \& WANG, supra note 17 , at 12.

${ }^{245}$ See supra note 15 (noting the human rights community's push for flexible interpretations with regard to such areas as gender-based crimes, economic and social rights, and children's rights). 
Bush administration has misread or misapplied the law; in most cases, there is little basis for asserting this. ${ }^{246}$ The deeper problem is that the Bush administration is applying a body of law that is anachronistic in its categories and assumptions to novel developments that were never even imagined by the drafters of the Geneva Conventions. These anachronistic categories and assumptions, applied to the struggle against terrorism, lead not implausibly to the conclusions the Bush administration has drawn. They do not compel the legal conclusions of the Bush administration, but neither do they offer a firm basis for regarding the administration's conclusions as unlawful.

Once again, of course, to say that the administration's interpretations of the laws of armed conflict are plausible is neither to support the policy decisions that underlie the choice of legal paradigms, nor to accept as inevitable or appropriate all of the consequences that flow from this choice. The human rights and civil rights law communities have been rightly dismayed by the consequences of the recent U.S. government actions that flow from the decision to conceptualize terrorism as "war" rather than "crime." In effect, the decision to make use of legal paradigms relating to armed conflict have brought us into the era of "war everywhere," and rather than a war to end all wars, we are now in a war without end. But because the traditional distinctions drawn by the law of armed conflict lose their analytic force when applied to the "war on terror," we are also in a war where, more or less, anything goes.

If the war knows no geographical or temporal boundaries, if no one deemed an enemy enjoys any of the protections envisioned by the law of armed conflict, and if the line between terrorist combatants and terrorist civilians makes no sense, then there are very few legal constraints on U.S. behavior abroad. U.S. forces can attack, capture, detain, and kill with impunity, subject, of course, to political and diplomatic constraints, but virtually unfettered by legal constraints. To be sure, it is true that even in earlier periods, there has been no effective international legal enforcement mechanism able to restrain U.S. behavior abroad in matters relating to national security. Nonetheless, the U.S. has to a significant degree internalized the law of armed conflict, and willingly accepted the constraints that flow from this body of law. ${ }^{247}$ Now, however, the law of armed conflict appears to dictate very

${ }^{246}$ The one glaring example of Bush administration misreading of the law involves the debate about interrogation practices. See supra note 20.

${ }^{247}$ Even since $9 / 11$, the U.S. government has consistently sought to justify its conduct by reference to the law of armed conflict. From the war in Iraq to U.S. treatment 
few constraints, either internal or external, and this has had a spillover effect on other areas of the law that do contain clear guidelines, such as prohibitions on torture.

The erosion of traditional boundaries has left U.S. behavior abroad alarmingly unconstrained, and it has also left U.S. government behavior relatively unconstrained domestically. Faced with the perpetual threat of terrorism, the U.S. government has every incentive to restrict civil liberties at home and to treat the home front as a war zone when doing so suits governmental purposes. As a result, the government claims the right to strip even U.S. citizens of all constitutional protections on the basis of unreviewable executive branch assertions that a citizen is an "enemy combatant." With courts so far adhering, for the most part, to traditional canons of judicial deference to government actions undertaken in the name of national security, ${ }^{248}$ here, too, anything goes.

\section{What CaN BE DONE? HuMaN RIGHTS LAW AS A BASIS FOR CRITIQUE}

I have argued here that the law of armed conflict is of little use in placing constraints on the war on terror. The law of armed conflict, which has long been criticized as based on unrealistic conceptions of conflict, has now been undermined almost completely by the rise of a new kind of armed conflict, which is one never envisioned by the drafters of the Geneva Conventions. As a result of the conundrums posed by the rise of global terrorism and similar asymmetrical threats, states such as the U.S. can technically comply with the law of armed conflict, while in fact evading most of the constraints that the law of armed conflict intended to place on states. Likewise, most of the rights and persons that the law of armed conflict intended to protect are no longer protected, since the U.S. can plausibly claim that in this war, which is everywhere and forever, no enemies are lawful combat-

\footnotetext{
of Guantanamo detainees, U.S. government officials have, for the most part, taken care to situate U.S. actions and arguments within the standard international law discourse. We continue to behave as if we believe that law matters; the problem, as noted, is not that the United States refuses to accept the constraints of the law, but that the applicable law does not in fact provide any real constraints.

${ }^{248}$ Although the Supreme Court's decisions in Hamdi and Rasul were widely viewed as setbacks to Bush administration assertions of virtually unlimited executive power, the decisions did not in practice go far to erode executive power. The Hamdi Court was only able to agree that Hamdi was entitled to argue his case before a "neutral decisionmaker," and Rasul was restricted to the jurisdictional question. Hamdi v. Rumsfeld, 124 S. Ct. 2633, 2635 (2004); Rasul v. Bush, 124 S. Ct. 2686, 2690 (2004).
} 
ants and few people are truly civilians. Domestically, the war on terror gives the U.S. government virtual carte blanche to restrict even the most seemingly entrenched constitutional rights with, for the most part, judicial acquiescence.

In the longer run, this problem can only be solved through a radical reconceptualization of national security law and the international law of armed conflict. Just as the international community has come together in unprecedented ways to create an international landmines treaty, a treaty creating an international criminal court, and to modify the laws of armed conflict in other ways (such as through the Optional Protocol to the Convention on the Rights of the Child on the Involvement of Children in Armed Conflict ${ }^{249}$ ), so too the international community might be able to come together to reconsider the Geneva Conventions once more.

I do not expect this to happen soon, however; the current U.S. administration would almost certainly be opposed to any such enterprise, just as it has been opposed to the International Criminal Court and a range of other recent international legal innovations. What is more, if the U.S. nevertheless participated in such an enterprise, its interventions might not be for the best, from a rights perspective. In the shorter run, human rights and civil rights law advocates need to find some other alternative legal basis for critiquing U.S. actions, and simultaneously begin the project of reconceptualizing the law of war for a new era.

It would be facile to claim that there is any obvious solution to the dilemmas I have outlined in this Article, which will persist for the foreseeable future. Nevertheless, I think that international human rights law may offer some partial, interim solutions, and may ultimately point the way to reinventing the law of armed conflict.

Unlike the law of armed conflict, international human rights law applies to all persons at all times, regardless of nationality, status, or location, and for the most part, international human rights law applies in times of war as much as in times of peace. International human rights law offers basic guarantees of due process, equal protection, and humane treatment, and suggests an alternative framework for analyzing and critiquing U.S. government actions in the war on terrorism.

${ }^{249}$ Supra note 46, S. TREATY DOC. NO. 106-37, 39 I.L.M. at 1285. 
Core international human rights norms are laid out in the 1948 Universal Declaration of Human Rights. ${ }^{250}$ Though it is not itself a legally binding treaty, many of the basic principles outlined in the Universal Declaration have since been accepted as norms of customary international law that are binding on all states except those that have persistently objected. ${ }^{251}$ The U.S. and most other states are also party to the International Covenant on Civil and Political Rights (ICCPR), which prohibits, among other things, arbitrary deprivation of life; discrimination on the basis of race, color, sex, language, religion, political opinion, national or social origin; the denial of equal protection of the law to any person; arbitrary interference with privacy, family, home or correspondence; arbitrary arrest or detention; denial of judicial review of detentions; and denial of compensation for unlawful detentions. $^{253}$

The ICCPR does permit states to derogate from some of the rights laid out in the treaty, but only "[i]n time of public emergency which threatens the life of the nation and the existence of which is officially proclaimed." ${ }^{254}$ Any measures taken by a state in derogating from obligations under the ICCPR must be limited to those measures "strictly required by the exigencies of the situation," and to those measures that "are not inconsistent with [a state's] other obligations under international law" and that "do not involve discrimination solely on the ground of race, colour, sex, language, religion or social origin." Derogating states must formally declare their intention to derogate by "immediately inform[ing] the other States Parties to the present Covenant." ${ }^{256}$

${ }^{250}$ G.A. Res. 217A, U.N. Doc. A/810, at 71 (1948), available at http://www.un.org/ documents/ga/res/3/ares3/htm (last visited Nov. 26, 2004).

${ }^{251}$ See, e.g., Perry S. Smith, Speak No Evil: Apostasy, Blasphemy and Heresy in Malaysian Syariah Law, 10 U.C. DAvIS J. INT'L L. \& POL'Y 357, 368-69 (2004) (stating that the Universal Declaration of Human Rights binds all nations not able to establish "persistent objector" status).

${ }^{252}$ International Covenant on Civil and Political Rights, Dec. 19, 1966, 999 U.N.T.S. 171.

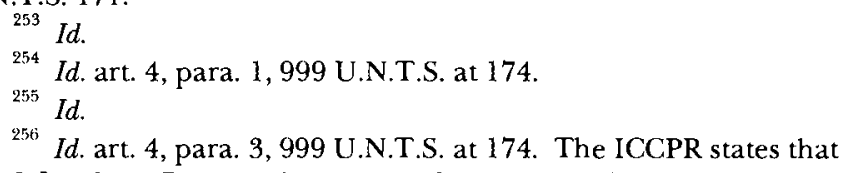

[a]ny State Party to the present Covenant availing itself of the right of derogation shall immediately inform the other States Parties to the present Covenant, through the intermediary of the Secretary-General of the United Nations, of the provisions from which it has derogated and of the reasons by which it was actuated. A further communication shall be made, through the same intermediary, on the date on which it terminates such derogation. 
In any case, even in time of public emergency, the ICCPR prohibits derogation from articles $6,7,8.1,8.2,11,15,16$ and $18 .^{257}$ These articles establish the right to life and the right to be free of arbitrary deprivation of life; the right to be free of torture or other cruel, inhuman and degrading treatment; the prohibition on slavery, the prohibition against ex post facto criminal laws, the right to be treated as a person before the law, and the right to freedom of thought, conscience and religion. ${ }^{258}$

Some of the norms articulated in the Universal Declaration, the ICCPR, and other human rights law treaties such as the Genocide and Torture Conventions $^{259}$ are generally accepted as having risen to the status of jus cogens, "peremptory norms" of international law that are binding on all states at all times, and that states cannot barter away via treaty or other agreement. ${ }^{200}$ Although there is some disagreement over precisely which international human rights norms have attained jus cogens status, most commentators (including the drafters of the $R \boldsymbol{e}$ statement (Third) of the Foreign Relations Law of the United States) agree that at a minimum, the norms against genocide; slavery; murder and "disappearance" of individuals; torture or other cruel, inhuman, or degrading treatment or punishment; prolonged arbitrary detention; and systematic racial discrimination are peremptory in nature. ${ }^{261}$ These norms are binding at all times, whether in emergency situations or not, and whether in armed conflicts or not.

Thus, the U.N. Committee on Civil and Political Rights (which was established by the ICCPR) has observed that despite the derogations permitted in times of emergency by the ICCPR, "[s] tates parties may in no circumstances invoke [the derogation clauses] of the Covenant as justification for acting in violation of ... peremptory norms of international law, for instance ... through arbitrary deprivations of liberty or by deviating from fundamental principles of fair trial, including the presumption of innocence." ${ }^{262}$ The Committee has also noted

$I d$.

${ }^{257}$ Id. art. 4, para. 2, 999 U.N.T.S. at 174.

${ }^{258} I d$. at arts. $6,7,8$, paras. $1 \& 2,11,15 \& 16$.

${ }^{259}$ Convention Against Torture and Other Cruel, Inhuman or Degrading Treatment or Punishment, Dec. 10, 1984, 1465 U.N.T.S. 85; Convention on the Prevention and Punishment of the Crime of Genocide, Dec. 10, 1948, 78 U.N.T.S. 277. The United States is a party to both of these conventions.

${ }^{260}$ See FOREIGn RELATiONS LAW, supra note $48, \S 702$ (listing the policies, which if instituted by a state, will deem it to have violated international law).

${ }^{261} \mathrm{Id}$.

${ }^{262}$ U.N. Human Rights Comm., General Comment No. 29, States of Emergency 
that implicitly, "[i]n order to protect non-derogable rights, the right to take proceedings before a court to enable the court to decide without delay on the lawfulness of detention, must not be diminished by a State party's decision to derogate from the Covenant." ${ }^{263}$

At a time when neither domestic jurisprudence nor the law of armed conflict appears to offer a principled and coherent basis for critiquing U.S. government infringements on rights resulting from the war on terror, these norms of international human rights law may offer a useful alternate framework. ${ }^{264}$ They provide an alternative legal yardstick against which we can measure the appropriateness of the indefinite detentions at Guantanamo, the effectively indefinite detentions of U.S. citizens such as Jose Padilla and Yaser Hamdi, and the similar detentions of numerous immigrants in the United States. ${ }^{265}$

Thus, although the Geneva Conventions do not clearly preclude the indefinite detention of those who the U.S. has declared "unlawful

(Article 4), at 5, U.N. Doc. CCPR/C/21/Rev.1/Add.11 (2001).

${ }^{269}$ Id. at 6 .

${ }^{264}$ Numerous international treaties and agreements relating to terrorism exist, but these address the issue only in a piecemeal fashion and none focus on the issue of balancing the need to fight terrorism with protection of rights. See, e.g., International Convention for the Suppression of the Financing of Terrorism, Jan. 10, 2000, art. 2, S. TREATY DOC. No. 106-49, at 4-5, 39 I.L.M. 270, $271-72$ (defining when the offense of terrorism is committed); Convention for the Suppression of Terrorist Bombings, Jan. 12, 1998, art. 2, S. TREATY Doc. No. 106-6, at 4-5, 37 I.L.M. 249, 253 (defining when the offense of terrorist bombing is committed); Convention on the Marking of Plastic Explosives for the Purpose of Detection, Mar. 1, 1991, arts. 2-4, S. TREATY DoC. No. 103-8, at 3-4, 30 I.L.M. 726, 727-28 (describing all necessary measures that a State Party must take to prohibit unmarked explosives); Convention for the Suppression of Unlawful Acts Against the Safety of Maritime Navigation, Mar. 10, 1988, art. 3, S. TREATY Doc. No. 101-1, at 2-3, 27 I.L.M. 668, 674-75 (defining an unlawful act against the safety of maritime navigation); Convention on the Physical Protection of Nuclear Material, Mar. 3, 1980, art. 7, T.I.A.S. No. 11080, at 11, 18 I.L.M. 1422, 1425-26 (defining offenses regarding nuclear materials); Convention Against the Taking of Hostages, Dec. 17, 1979, T.I.A.S. No. 11081, 18 I.L.M. 1456 (providing definitions regarding hostage-taking and guidelines for preventing it); Convention on the Prevention and Punishment of Crimes Against Internationally Protected Persons, Dec. 14, 1973, art. 2, 28 U.S.T. 1975, 1978, 1035 U.N.T.S. 167, 169 (defining crimes against internationally protected persons). For a discussion of this patchwork approach to terrorism, see Laura A. Dickinson, Using Legal Process to Fight Terrorism: Detentions, Military Commissions, International Tribunals, and the Rule of Law, 75 S. CAL. L. REV. 1407 (2002) (arguing for the relevance of international legal norms in the fight against terrorism and against the Bush administration's use of military commissions).

${ }^{265}$ See generally Michael Beattie \& Lisa Yonka Stevens, Comment, An Open Debate on United States Citizens Designated as Enemy Combatants: Where Do We Go from Here?, $62 \mathrm{MD}$. L. REV. 975 (2003) (presenting arguments for and against executive detention of enemy combatants and examining the need for Article III courts to safeguard citizenship rights of American detainees). 
combatants," the indefinite and arguably arbitrary nature of the detentions, ${ }^{266}$ and the lack of any mechanism for judicial review, renders these detentions likely violations of jus cogens norms. Similarly, many of the provisions of the USA PATRIOT Act and many executive branch actions would appear to run afoul of ICCPR provisions.

It should be immediately acknowledged that international human rights law is no panacea in the present situation. First of all, although human rights law may be of great use in evaluating the lawfulness of detentions, international human rights law contains few norms that would help determine whether and when the use of military force is justified. ${ }^{267}$ While the law of armed conflict does not supplant international human rights law in times of conflict, neither can international human rights law displace core principles of the U.N. Charter or the laws of armed conflict.

Thus, international human rights law does not provide a satisfying answer to the question of whether the U.S. predator drone missile attack on a car full of suspected al Qaeda operatives in Yemen was justified. $^{268}$ Human rights law forbids murder and the arbitrary depriva-

${ }^{266}$ The detentions have been challenged as arbitrary because the United States has never articulated the basis on which it decides who should be sent to Guantanamo and who should be detained elsewhere, released, or transferred to another state. Although the secrecy surrounding the Guantanamo detainees makes it difficult to say much of anything for certain, what is known about the detainee population does suggest a certain degree of arbitrariness. Some Guantanamo detainees were as young as thirteen; others were apparently in their nineties. Some were detained in Afghanistan, some in other countries. See LAWYERS COMM. FOR HUMAN RIGHTS, supra note 11, at 5255 (describing the plight of Guantanamo detainees); see also Lepri, supra note 7, at 2597-98 (concluding that detainees should have a right to counsel and fair trial, and that the government should be required to justify detentions by a showing of probable cause); Samantha A. Pitts-Kiefer, Note, Jose Padilla: Enemy Combatant or Common Criminal?, 48 VILL. L. REV. 875, 898-904 (2003) (distinguishing Padilla from Quirin and concluding that Padilla's detention is invalid); Irma Alicia Cabrera Ramirez, Comment, Unequal Treatment of United States Citizens: Eroding the Constitutional Safeguards, 33 GOLDEN GATE U. L. REV. 207, 247-50 (2003) (arguing that enemy combatants should have the legal rights of criminal defendants); Rodriguez, supra note 184, at 394 (declaring that judicial review is required to prevent a "slippery slope" of lost liberties in the war on terror).

${ }^{267}$ Indeed, for that reason, most human rights groups refrain from taking positions on the use of military force in the abstract, although some organizations have policies on humanitarian intervention. See, e.g., Ken Roth, War in Iraq: Not a Humanitarian Intervention, in HUMAN RIGHTS WATCH WORLD REPORT (2004) (stating that Human Rights Watch would refrain from evaluating other justifications for military action, but concluding that "the invasion of Iraq cannot be justified as a humanitarian intervention").

${ }^{268}$ See. e.g., Priest, supra note 162, at Al (describing the CIA killing of a U.S. citizen in a country considered at peace with the United States). 
tion of life, but the law of armed conflict permits the killing of enemy combatants, including surprise attacks made at moments when the enemy combatants are not themselves directly engaged in acts of violence. Perhaps the most that can be said about a case such as this is that given the ambiguity of whether the laws of armed conflict were applicable, the uncertainty about the identities of some of the car's occupants, and the possible existence of alternative means of stopping the car and apprehending its occupants, human rights norms suggest that the U.S. should bear the burden (politically and diplomatically, if not legally) of making a convincing case that the killings were neither arbitrary nor unnecessary.

A second problem with using international human rights law to address U.S. actions in the war on terror is that no international tribunal exists that can determine whether the U.S. has violated human rights law and can enforce judgments against the U.S. ${ }^{269}$ At the same time, the domestic status of international human rights law is unclear. While the Supreme Court has historically recognized that international law is part of U.S. law, a combination of limiting doctrines (including the "last in time" rule, and the presumption that treaties are not self-executing) and judicial ignorance of international law often means that courts will not enforce international human rights law, especially against the U.S. government. ${ }^{270}$

These problems are real, but I think that there is nevertheless value in using international human rights law as a framework for evaluating U.S. government actions in the war on terror. International human rights law cannot fill every conceptual gap that results from efforts to apply the laws of armed conflict to threats such as ter-

${ }^{26: 5}$ The International Court of Justice's lack of capacity to enforce its judgments and the optional nature of U.S. acceptance of I.C.J. jurisdiction make it an ineffective tribunal vis-à-vis the United States; and the United States has refused to accept the jurisdiction of the Inter-American Court of Human Rights or the new International Criminal Court.

${ }^{270}$ Courts have shown more willingness to apply and enforce international human rights law against foreign actors, particularly in cases brought under the Alien Tort Claims Act, 28 U.S.C. $\$ 1350$ (2000), and, more recently, under the Torture Victims Protection Act of 1991, Pub. L. No. 102-256, 106 Stat. 73 (codified at 28 U.S.C. $\$ 1350$ (2000)). See generally Ivan Poullaos, Note, The Nature of the Beast: Using the Alien Tort Claims Act to Combat International Human Rights Violations, 80 WASH. U. L.Q. 327, (2002) (seeking to expand the legal tools available to victims of human rights abuses). The Court recently gave a cautious green light to the continued use of the Alien Tort Claims Act. In Sosa v. Alvarez-Machain, 124 S. Ct. 2739 (2004), the Court held that "any claim based on the present day law of nations [must] rest on a norm of international character accepted by the civilized world and defined with a specificity comparable" to the torts recognized by the First Congress. Id. at 2761-62. 
rorism, but something is still better than nothing. And although U.S. courts have mostly declined to enforce international human rights law directly against the U.S. government, human rights norms can and should still inflect the policy discourse. The law of armed conflict is similarly not directly enforceable in U.S. courts or in any international tribunals with effective jurisdiction over the U.S., but the U.S. government nonetheless acknowledges the political importance of justifying U.S. actions as consistent with the law of armed conflict.

U.S. courts have indicated a growing willingness to consider international human rights law, at least as one of many relevant factors in determining the justifiability of government actions. Thus, in Atkins $v$. Virginia, the U.S. Supreme Court declared the execution of mentally retarded offenders to be a violation of the Eighth Amendment's prohibition on cruel and unusual punishment. ${ }^{271}$ The Court noted that "within the world community, the imposition of the death penalty for crimes committed by mentally retarded offenders is overwhelmingly disapproved." 272 The Court based this observation mainly on an amicus curiae brief submitted by the European Union, which argued that in the European Union and in most states around the world, the practice of executing mentally retarded offenders is considered a violation of international human rights norms. ${ }^{273}$

Similarly, in Grutter v. Bollinger, Justice Ginsburg's concurrence noted the relevance of international human rights standards in evaluating the constitutionality of race-conscious affirmative action programs. ${ }^{274}$ Likewise, in Laurence $v$. Texas, the Supreme Court concluded that a state law criminalizing homosexual sex between consenting adults violated the Fourteenth Amendment; writing for the majority, Justice Kennedy cited decisions of the European Court of Human Rights in support of this conclusion. ${ }^{275}$

\footnotetext{
${ }^{271}$ Atkins v. Virginia, 536 U.S. 304, 321 (2002).

${ }^{272} I d$. at 316 n. 21 .

${ }^{273} I d$. (citing Brief for European Union as Amicus Curiae at 4, Atkins, 536 U.S. at 304).

${ }^{274}$ Grutter v. Bollinger, 539 U.S. 306, 344 (2003) (Ginsburg, J., concurring). Justice Ginsburg referred in particular to the the International Convention on the Elimination of All Forms of Racial Discrimination and the Convention on the Elimination of All Forms of Discrimination Against Women (only the first of which the United States has ratified). Convention on the Elimination of All Forms of Discrimination Against Women, Dec. 18, 1979, 1249 U.N.T.S. 13; International Convention on the Elimination of All Forms of Racial Discrimination, Dec. 21, 1965, 660 U.N.T.S. 195.

${ }^{275}$ Lawrence v. Texas, 539 U.S. 558, 573 (2003).
} 
Most recently, in Sosa v. Alvarez-Machain, ${ }^{276}$ the Supreme Court gave a cautious green light to the continued use of 28 U.S.C. $\S 1350$ (the "Alien Tort Statute") by foreign nationals seeking civil remedies against egregious human rights violators. The Court took a narrow approach to determining which human rights violations are actionable under $\S 1350$, limiting $\$ 1350$ to claims that "rest on a norm of international character accepted by the civilized world and defined with a specificity comparable" to the torts recognized by the First Congress as violating the law of nations. ${ }^{277}$ Despite this narrow approach, the decision in Sosa appeared to confirm that violations of such jus cogens norms as genocide, torture, and extrajudicial killings fit this standard, and thus create causes of action under the Alien Tort Statute. The Sosa decision makes it clear that judges may look to evolving international norms as they seek to delineate appropriate claims under $\$ 1350$. Perhaps most intriguingly, in Rasul v. Bush, ${ }^{278}$ announced one day prior to Sosa, the Court affirmed that the alleged enemy combatants detained at Guantanamo can use the federal courts to pursue claims under the Alien Tort Statute. Implicitly, this suggests that the Court is open to the possibility that foreign nationals detained as terror suspects could successfully bring suit against U.S. officials for violations of international human rights law.

It would not be wise to assume from this that U.S. courts will, from now on, consistently accept the relevance of international human rights law when evaluating U.S. government actions. But these decisions do offer some hope that U.S. courts will be willing to take arguments based on human rights law into account if lawyers consistently raise these issues. Thus, for instance, litigants seeking to overcome the usual judicial deference to the government in matters affecting national security might cite jus cogens norms and the ICCPR's approach to derogability as part of an effort to convince courts that, even in time of armed conflict, governments still have an international law obligation to respect core rights, and to ensure that derogations of rights, when permissible, be limited "to the extent strictly required by the exigencies of the situation."279

${ }^{276} 124$ S. Ct. 2739 (2004).

277 Id. at 2761 .

278 124 S. Ct. 2686 (2004).

${ }^{279}$ This suggests a standard of review that would be roughly parallel to the U.S. judicial doctrine of "strict scrutiny." Based on this, some scholars have asserted that various U.S. actions taken post-9/11 amount to derogations (and arguably impermissible derogations) from the ICCPR. Thus, Elizabeth Dahlstrom notes that while it might or might not be reasonable to characterize the $9 / 11$ attacks as something that "threat- 


\section{REINVENTING THE LAW OF ARMED CONFLICT}

The task of fully reconceptualizing the law of armed conflict is far beyond the scope of this article. Nonetheless, in light of core human rights principles, it is possible to imagine some salutary changes based upon the experiences of the past decades and, in particular, upon the lessons of the post-9/11 "war on terror." A reinvented law of armed conflict would have as its twin goals the preservation of life and security and the preservation of due process and the rule of law.

To begin with, a modernized law of armed conflict would abandon the archaic distinction between "international" and "internal" armed conflict and the resulting difference in the rules that apply. Few scholars would mourn the elimination of this distinction, which has long been decried as one that "frustrates the humanitarian purpose of the law of war in most of the instances in which war now occurs." ${ }^{280}$ In an era in which many conflicts are not between two or more states, but are instead between a state and a nonstate actor, or between two or more nonstate actors, the old assumptions about state centrality no longer serve any purpose. A modernized law of armed

ens the life of the nation," the United States has, as a threshold matter, ignored the ICCPR's procedural requirements governing derogation: "[A]s of December 2002, the United States ha[d] not announced such an intention to suspend its obligations under the ICCPR, as required by Article 4(3)." K. Elizabeth Dahlstrom, The Executive Policy Toward Detention and Trial of Foreign Citizens at Guantanamo Bay, 21 BERKELEY. J. INT'L L. 662, 670 (2002). Similarly, the late Joan Fitzpatrick argued that many aspects of the Bush administration's plan to try war on terror detainees in military commissions amounted to impermissible derogations from U.S. obligations under the ICCPR:

The November 13 order, in section $\$ 7$ (b) (2), includes a startling clause:

the individual [subject to detention] shall not be privileged to seek any remedy or maintain any proceeding, directly or indirectly, or to have any such remedy or proceeding sought on the individual's behalf, in (i) any court of the United States, or any State thereof, (ii) any court of any foreign nation, or (iii) any international tribunal.

This executive claim to displace the jurisdiction of federal and state courts, foreign courts, and international tribunals is questionable on many grounds. For human rights purposes, what is most significant is that the order does not purport to suspend the writ of habeas corpus, and fails to mention 28 U.S.C. $\S$ 2241. The jurisdiction of U.S. military commissions sitting inside and outside the United States has been subject to habeas corpus review, even where no direct judicial appeal from conviction is permitted.

[Yet] [t]he [ICCPR] Human Rights Committee in General Comment No. 29 affirms the nonderogability of judicial proceedings to challenge the lawfulness of detention.

Fitzpatrick, supra note 148, at 352 (first alteration in original) (footnote omitted).

${ }^{280}$ Reisman \& Silk, supra note 23, at 465 . See generally Stewart, supra note 23 (arguing that the distinction between "international" and "internal" conflict should be abandoned and replaced by a single law of armed conflict). 
conflict should apply to all armed conflicts, even those not currently covered even by Additional Protocol II of the Geneva Conventions, such as clashes between two insurgent groups, clashes between insurgents and police or state-sponsored paramilitary groups (rather than regular military forces), and clashes with insurgent forces that have a decentralized command structure or lack a territorial base.

The definition of "armed conflict" should also be explicitly expanded to cover the kinds of attacks that well-organized terrorist groups like al Qaeda can undertake. Here, of course, one immediately encounters difficulties. Traditionally, nothing in the law of armed conflict applies to "situations of internal disturbances and tensions, such as riots, isolated and sporadic acts of violence and other acts of a similar nature. ${ }^{281}$ This rule makes sense in principle; its intention is clearly to leave to domestic and international criminal law those acts of violence that fall below a certain threshold. Nevertheless, a new law of armed conflict should recognize that when the same organization (state or nonstate) is behind repeated and serious acts of politically motivated violence ${ }^{282}$ that are nonetheless discontinuous in time and space, any party to the conflict may invoke the law of armed conflict. There is likely no way to draw a bright-line rule delineating how much and how often violence must occur to be sufficient, but a reinvented law of armed conflict might include standards and examples to make such determinations easier.

A new law of armed conflict would also abandon anachronistic definitions of presumptively "lawful" combatants. Status as a lawful combatant should not hinge on whether a person is "commanded by a person responsible for his subordinates," has a "fixed distinctive sign recognizable at a distance" (e.g, a uniform or other sign by which combatants can be visually distinguished from civilians), or whether

${ }^{281}$ Additional Protocol II, supra note 43, art. 1, 1125 U.N.T.S. at 611.

282 When considering how to distinguish between "crime" and "conflict," some commentators suggest that the motivation behind violence is one relevant factor. Though some armed conflicts may be motivated entirely by economic aims or a desire for personal revenge, and some crimes may be motivated by ideology, it may make sense to see politically motivated violence as more typical of "conflict," with economically motivated violence more typical of "crime." Thus one might have a default assumption that terrorism is a form of armed conflict, while the violence associated with international drug smuggling is a form of crime. See Roth, supra note 13, at 2 (discussing how the Bush administration's broad concept of "war" in the "war on terrorism" has troubling implications for humanitarian and due process rights). Here too, however, it would be unwise to replace the old bright-line rules with new bright-line rules because, empirically, terrorism and illicit economic activity are often entangled with one another. 
she "carr[ies] arms openly." 283 Few can meet these requirements in today's conflicts. Even U.S. Special Forces soldiers often wear clothing not readily recognizable as "uniforms," and the requirement that a combatant carry arms "openly" is meaningless because much killing takes place at a distance when weapons cannot be detected by the naked eye. The requirement of a clear command hierarchy also fails to take into account the decentralized nature of many modern armed groups.

It would be far better to make combatant status a purely functional question, one that hinges not on technicalities, but on the degree to which a person is directly, actively, and primarily involved in knowingly or intentionally planning or carrying out acts of violence. Here, too, standards are probably more appropriate than rules. The goal is to differentiate, for instance, between those who are "incidental" terrorists and those for whom terrorism is a primary goal and identity. Thus, it would perhaps have been appropriate to treat the September 11 hijackers, had any survived, as combatants, while treating the clerks who provided false identification documents to the hijackers as criminals.

Adopting such a functional definition of combatant would not, of course, require that all combatants be treated as "lawful" combatants entitled to immunity for their actions. An otherwise lawful combatant would lose her entitlement to combatant immunity by engaging in substantive violations of the law of armed conflict (through attacks that intentionally target civilian populations, or through the use of torture or sexual violence). This is an aspect of the law of armed conflict that need not and should not change. Combatants who commit war crimes or crimes against humanity should be subject to trial and

${ }^{283}$ Third Geneva Convention, supra note 10 , art. 4, 6 U.S.T. at $3320-22,75$ U.N.T.S. at 138-40. The Geneva Conventions state that members of regular state armed forces are lawful combatants unless they fail to comply with the substantive laws of war, such as the prohibition on the intentional targeting of protected persons, etc. See Fourth Geneva Convention, supra note 10, art. 3, 6 U.S.T. 3518-20, 75 U.N.T.S at 136-38 (delineating acts prohibited to lawful combatants). "Members of other militias and members of other volunteer corps," however, are only lawful combatants if they meet the additional requirements of responsible command, distinctive sign, etc. But by custom, this is deemed to apply to all combatants, including combatants with regular armies. See Third Geneva Convention, supra note 10, art. 4, 6 U.S.T. at 3320-22, 75 U.N.T.S at 138-40 (listing the requirements for considering soldiers who are not members of regular armed forces to be lawful combatants).

${ }^{284}$ See W. Hays Parks, Special Forces' Wear of Non-Standard Uniforms, 4 CHI. J. INT'L L. 493, 496 (2003) (discussing whether U.S. forces were in violation of the laws of war for wearing "civilian clothing" during operations in Afghanistan in 2001 and 2002). 
punishment for their acts, whether in civilian courts or military commissions.

A reconceptualized law of armed conflict would also recognize the importance of due process in modern conflicts that have no clear spatial or temporal boundaries. The war on terrorism may well be everywhere and forever, but this cannot become a reason to permanently deprive suspected terrorists of their freedom or their lives when other alternatives exist. Due process is not an all-or-nothing affair. Concretely, this means that regardless of the citizenship, place of detention, or circumstances of detention, any person detained and asserted to be a combatant by the opposing party should have certain minimal due process rights, and these rights should exist regardless of whether military or civilian authorities exercise control over the detainee.

These minimum process rights should include the right to an individualized determination of combatant/noncombatant status within a reasonable period of time (perhaps three to six months); the right to assistance of counsel in such a hearing (with the understanding that the detaining power could require that counsel be drawn from a pool of attomeys with appropriate security clearances); the right to periodic review hearings (perhaps yearly) to assess the ongoing dangerousness of a detainee and the right to counsel at such hearings; the right to be released if a review panel determines that a detainee is no longer a threat; the right to a reasonably expeditious trial (whether in a civilian court or a fairly constituted military court) if the detaining power designates a detainee an "unlawful" combatant on the grounds that she may have committed war crimes or crimes against humanity; and the right to appeal any adverse decision, whether administrative or judicial.

None of these due process rights need be particularly burdensome to a detaining power; all could be subject to ordinary "reasonableness" requirements. In its recent decisions to grant limited access to counsel to Padilla and Hamdi, ${ }^{285}$ to release dozens of Guantanamo detainees, ${ }^{286}$ to permit other detainees a periodic administrative review of "dangerousness," before military commissions, ${ }^{288}$ the U.S. has effectively acknowledged that providing minimal due process rights to detainees is not irrecon-

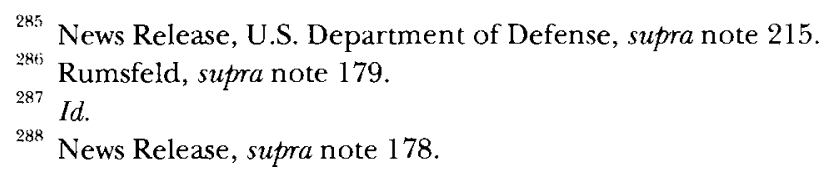


cilable with protecting national security interests. The U.S. has only made these moves grudgingly and as a matter of discretion, however. A reimagined law of armed conflict would grant basic due process to all detainees as a matter of right.

To safeguard these rights, a new law of armed conflict should also require detaining powers to permit expanded monitoring of conditions and proceedings by intergovernmental and nongovernmental organizations and by the press. Here too, detaining powers have a legitimate interest in safeguarding sensitive security-related information, but a new law of armed conflict would mandate judicial proceedings if necessary to determine the validity of claims regarding the need to limit access to detainees or information about detainees. Such proceedings might take place in camera and might involve specially trained and cleared judges, but some mechanism for deciding questions of access should be adopted. As a general principle, there should be no government actions that are not subject to subsequent judicial review, regardless of whether or not an armed conflict exists at the time the government actions are taken.

There are some issues, as Part VI notes, that are not readily resolved by reference to basic human rights principles, and for which it is difficult to come up with adequate guidelines. Issues concerning the initial decision to use force fall into this category. As noted previously, the use of force itself is traditionally governed both by the law of armed conflict and by the U.N. Charter. Unfortunately, neither provides clear answers to such questions as the legality of the November 2002 U.S. missile attack on al Qaeda suspects in Yemen, which killed a U.S. citizen, among others. Once again, a new law of armed conflict would have to resort to standards rather than rules. Attacks such as the one in Yemen could be justified in the event that they are challenged, but the burden should fall on the attacking power to provide some evidence that the targets of the attack were in fact actively engaged in planning or carrying out acts of armed conflict, and that relying on criminal law rather than on military force to stop the planned violence was not a reasonable alternative. ${ }^{289}$

These suggestions for a revamped international law of armed conflict all have implications for U.S. domestic jurisprudence. This article

${ }^{289}$ As Kenneth Roth of Human Rights Watch has noted, this might well have been a plausible claim in the context of the 2002 Yemeni attack: "[T] he Yemeni government apparently lacked control over the area" in which the attack occurred, and "eighteen Yemeni soldiers had reportedly been killed in a prior attempt to arrest" the targets of the attack. Roth, supra note 11, at 242. 
has argued that the customary U.S. judicial deference to the government in times of war and national security crisis provides no safeguards in the context of the war on terror. Court deference to the executive and legislative branches in times of crisis has been previously justified on the grounds that such deference is temporary, and will cease when the crisis is over. But since the war on terror is likely to be with us more or less forever, courts should shift from an automatic presumption of deference when national security is invoked to a more searching inquiry into the reasonableness of particular government acts.

Once more, this is an issue of standards rather than rules. Instead of bright-line determinations that, for instance, government designation of a U.S. citizen as an enemy combatant suffices to deprive the detainee of all constitutional rights, courts should instead apply a heightened level of judicial scrutiny to government actions, asking whether the transfer of a U.S. citizen to military detention is in fact justified under the circumstances. Such a review would inquire into the detainee's own links to the armed conflict (the directness and level of her involvement in the hostilities) and also into the feasibility of alternative civilian proceedings, placing the burden on the government to demonstrate by clear and convincing evidence that the national interest would be seriously harmed by charging and trying the detainee for ordinary crimes in the civilian court system.

These suggestions are necessarily preliminary in nature. The law of armed conflict as it currently exists is the product of decades of evolution and substantial international consensus, and this Article can do no more than suggest the basic outlines of a reimagined and modernized law of armed conflict. Nonetheless, although the task of reconceptualizing the law of armed conflict is a difficult one, it is not an impossible one, as the points outlined above suggest.

\section{CONCLUSION}

Many commentators have already remarked on the difficulties of applying the law of armed conflict to the kinds of conflict that increasingly predominate in the modern world, and many others have struggled to find principled ways of deciding how much of the law of armed conflict, if any, is applicable to the war on terror. The threats to human and civil rights that flow from the war on terror have also been well documented and passionately debated. But the whole of the discourse on these issues has somehow been less than the sum of 
the parts. Few commentators have sought to consider all of these issues at once, and as a result the commentaries are fragmented.

This Article seeks to put all the pieces together in a new way. I have suggested that although most commentators are reluctant to accept it, we simply lack an adequate international legal paradigm for thinking about the changes brought about by the rise of global terrorism. The analytical underpinnings of the core distinctions drawn by the laws of armed conflict have broken down, and as a result, this body of law is no longer of much practical use in allowing us to determine which rights and persons merit protection.

The implications of this are far-reaching and troubling; we now face the specter of "war everywhere," and, in effect, rights nowhere, at least as far as the laws of armed conflict and domestic national security law are concerned. There is no easy solution to this problem in the short run, although as I have argued, international human rights law does fill some of the gaps and offer an alternative framework for evaluating the legality of the war on terror, both internationally and in domestic fora.

In the longer run, we need urgently to begin to imagine what a new law of armed conflict might look like, and I have made some preliminary suggestions here. Although a thorough reconceptualization of the law of armed conflict is beyond the scope of this Article, I have suggested some of the kinds of safeguards that would be consistent both with the need to protect ourselves and others from new kinds of security threats and with the need to safeguard basic rights. Reinventing the law of armed conflict in the age of terror will not be easy, but it is better to face the challenge directly than to pretend it does not exist. 